\begin{abstract}
UNIVERSIDADE DE SÃO PAULO
ESCOLA DE ENGENHARIA DE SÃO CARLOS

CENTRO DE RECURSOS HÍDRICO E ECOLOGIA APLICADA

PROGRAMA DE PÓS-GRADUAÇÃO EM CIÊNCIAS DA ENGENHARIA AMBIENTAL
\end{abstract}

PAULO PONCE ARROIO JUNIOR

\title{
AVALIAÇÃO DA PRODUÇÃO E TRANSPORTE DE SEDIMENTOS NA BACIA HIDROGRÁFICA DO RIO ITAQUERI, MUNICÍPIOS DE ITIRAPINA E BROTAS - SP
}

São Carlos - SP 

PAULO PONCE ARROIO JUNIOR

\section{AVALIAÇÃO DA PRODUÇÃO E TRANSPORTE DE SEDIMENTOS NA BACIA HIDROGRÁFICA DO RIO ITAQUERI, MUNICÍPIOS DE ITIRAPINA E BROTAS - SP}

Dissertação apresentada à Escola de Engenharia de São Carlos, da Universidade de São Paulo, como parte dos requisitos para obtenção do título de mestre em Ciências da Engenharia Ambiental.

Orientador: Prof. Dr. Frederico Fábio Mauad

São Carlos - SP 
AUTORIZO A REPRODUÇÃO TOTAL OU PARCIAL DESTE TRABALHO, POR QUALQUER MEIO CONVENCIONAL OU ELETRÔNICO, PARA FINS DE ESTUDO E PESQUISA, DESDE QUE CITADA A FONTE

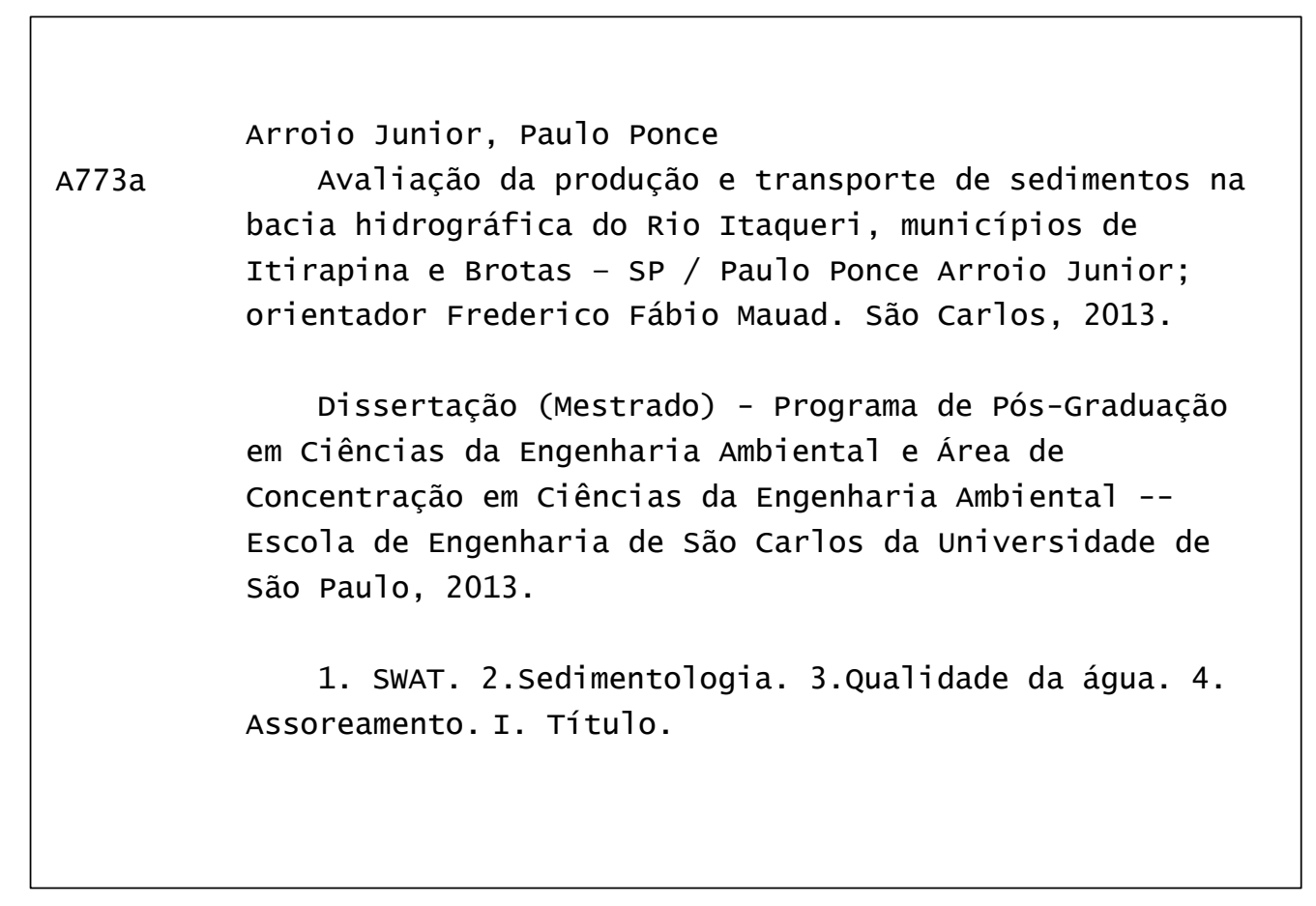




\section{FOLHA DE JULGAMENTO}

Candidato: Engenheiro PAULO PONCE ARROIO JUNIOR.

Título da dissertação: "Avaliação da produção e transporte de sedimentos na bacia hidrográfica do Rio Itaqueri, municípios de Itirapina e Brotas - SP".

Data da defesa: 22/02/2013

\section{Comissão Julgadora:}

Prof. Dr. Frederico Fabio Maud (Orientador)

(Escola de Engenharia de São Carlos/EESC)
Resultado:

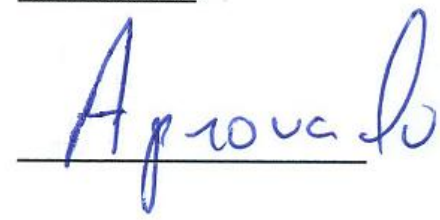

Prof. Dr. Sérgio dos Anjos Ferreira Pinto

(Universidade Estadual Paulista "Júlio de Mesquita Filho"/UNESP - Rio Claro)

Prof. Dr. Daniel Rigo

(Universidade Federal do Espírito Santo/UFES)

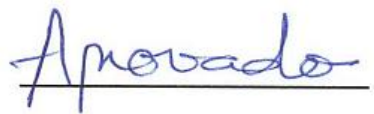

Coordenador do Programa de Pós-Graduação em Ciências da Engenharia Ambiental:

Prof. Dr. Frederico Fabio Mauad

Presidente da Comissão de Pós-Graduação:

Prof. Titular Denis Vinicius Coury 

Dedico este trabalho aos meus pais, Paulo e Rosimara, que sempre me deram apoio e incentivo em todas as etapas da minha vida. 



\section{AGRADECIMENTOS}

À minha família, pela dedicação, compreensão e paciência que tiveram durante todo este tempo e que, mesmo a distância, sempre me apoiou em todos os caminhos e decisões.

Ao Prof. Dr. Frederico Fábio Mauad, pela orientação, dedicação e suporte para realização deste trabalho.

Ao técnico hidrometrista Waldomiro Antonio Filho, pelo apoio técnico fornecido durante as campanhas de campo.

Ao Conselho Nacional de Desenvolvimento Científico e Tecnológico - CNPq, pela bolsa de mestrado fornecida.

À Dra. Juliana Moccellin, pelas contribuições dadas nas fases iniciais de definição do projeto de pesquisa e pelo auxílio nas etapas de campo e de laboratório.

Aos amigos de pesquisa Renato Billia, Júlio Issao, Marcus Estigoni, Norvin Requena, André Camargo, Diego Mendonça, Gustavo Scarpinella e Daniel Okamoto, por todas as dicas, auxílios e momentos divididos durante a realização deste trabalho.

Ao Centro de Recursos Hídricos e Ecologia Aplicada (CRHEA), pela oportunidade de realização desta pesquisa e aos seus funcionários: Nelson, Zé Luiz, Cidão, Regina, Betão e Humberto, pelo suporte no desenvolvimento das atividades.

Aos amigos de longa data Tiago, Ariane e Alysson, por colaborarem com conselhos e opiniões na pesquisa e pelos bons momentos vividos em São Carlos.

A todas as outras pessoas que não foram citadas aqui, mas que de alguma forma colaboraram com este trabalho. 



\section{RESUMO}

\section{ARROIO JUNIOR, P. P. Avaliação da produção e transporte de sedimentos na bacia} hidrográfica do Rio Itaqueri, municípios de Itirapina e Brotas - SP. 112 p. Dissertação (Mestrado em Ciências da Engenharia Ambiental) - Escola de Engenharia de São Carlos, Universidade de São Paulo, São Carlos, 2013.

Os processos de erosão e produção de sedimentos constituem eventos de grande relevância na atualidade, ocorrendo em escala global e ocasionando prejuízos nas esferas ambiental, econômica e social. Diversas pesquisas concentram seus esforços no sentido de entender as variáveis e os condicionantes destes fenômenos, os quais vêm sendo compreendidos por meio da multidisciplinaridade de diversas áreas do conhecimento. Nesse contexto, o presente estudo teve como objetivo realizar um diagnóstico da produção de sedimentos e de seu transporte na bacia hidrográfica do Rio Itaqueri, localizada nos municípios de Itirapina e Brotas - SP, na qual está inserido o Reservatório do Lobo ou do Broa. Dentre os elementos de análise, foi utilizado o simulador hidrossedimentológico SWAT para estimar a produção de sedimentos na bacia, bem como foi realizado o monitoramento da qualidade da água, a quantificação da carga sólida em suspensão e a determinação da granulometria do material de leito em seções de amostragem localizadas nos principais tributários do reservatório. Por meio da simulação, verificou-se que ocorrem na bacia áreas com diferentes comportamentos hidrossedimentológicos, com locais onde a produção anual média de sedimentos chega a 18 t/ha e outras áreas onde esta é próxima de zero. Foi constatado que o Rio Itaqueri contribuiu com $65 \%$ do total anual médio de sedimentos que chega ao reservatório, sendo neste rio também observados os maiores valores de carga sólida em suspensão. A parte alta da bacia configurou-se como uma área de maior aporte de sedimentos na rede de drenagem, sendo os reflexos desta dinâmica observados na qualidade da água destes locais, enquanto nas áreas de médio e baixo curso evidenciou-se a predominância de processos deposicionais. Verificou-se que as análises de parâmetros de qualidade da água e de caracterização do sedimento permitiram complementar os resultados obtidos pelo SWAT, fornecendo subsídios para uma melhor compreensão da dinâmica sedimentológica da bacia.

Palavras-chave: SWAT, sedimentologia, qualidade da água, assoreamento. 



\begin{abstract}
JUNIOR ARROIO, P. P. Evaluation of the production and transport of sediments in the Itaqueri River basin, Itirapina and Brotas cities, Brazil. 112 p. Dissertation (Master degree in Environmental Engineering Sciences) - Escola de Engenharia de São Carlos, Universidade de São Paulo, São Carlos, 2013.
\end{abstract}

The soil erosion and the sediment yield are considered one of the biggest present environmental problems, a worldwide issue that inflicts environmental, economic and social damages. Many researches have efforts to understand the variables and constraints of these phenomenon, which have been understood through the multidisciplinarity of different areas of knowledge. In this context, this study attempts to obtain a diagnosis of sediment yield and its transport in Itaqueri River basin, in which is inserted the Lobo-Broa Reservoir. The hydrosedimentological model SWAT was used to estimate the sediment yield in the basin, as well was performed the monitoring of water quality, the quantifying of suspended-sediment discharge and the determination of bed material particle size distributions in streams. Through simulation, it was observed that occur in the basin different hydrosedimentological behaviors, where the average annual production of sediments is $18 \mathrm{t} / \mathrm{ha}$, and it's null in some places. It was observed that Itaqueri River contributed $65 \%$ of total average annual sediment reaching the reservoir, and this river also has the highest values of suspended-sediment discharge. The upper part of the basin was shown as an area of major input of sediment in drainage network, influencing the water quality in these sub-catchments, while middle course and low course of the river revealed the predominance of depositional processes. Water quality parameters and characterization of river bed sediment supplemented the results obtained by SWAT model, supporting a better understanding of hydrosedimentological processes.

Keywords: SWAT, sedimentology, water quality, silting. 



\section{LISTA DE FIGURAS}

Figura 1 - Processos atuantes no transporte de sedimentos .................................................. 12

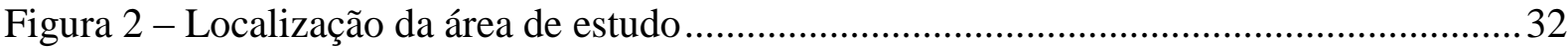

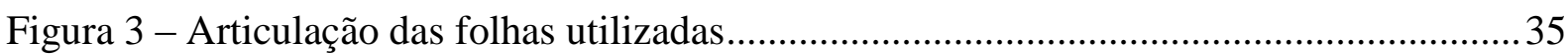

Figura 4 - Localização dos pontos de coleta de água e de sedimento nos tributários do

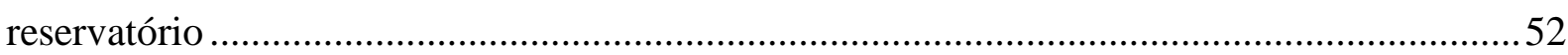

Figura 5 - Mapa hipsométrico da bacia do Rio Itaqueri .....................................................59

Figura 6 - Mapa das classes de declividade da bacia do Rio Itaqueri ....................................59

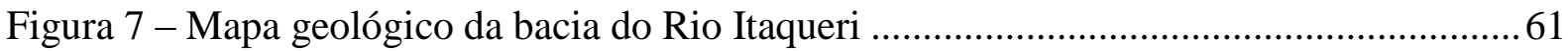

Figura 8 - Mapa geomorfológico da bacia do Rio Itaqueri.................................................... 63

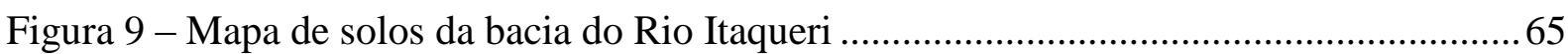

Figura 10 - Mapa de uso e ocupação da terra da bacia do Rio Itaqueri ...................................68

Figura 11 - Precipitação e temperatura média mensal no período de 1992 a 2011 ................. 70

Figura 12 - Média das temperaturas máxima e mínima mensal no período de 1992 a 2011...71

Figura 13 - Divisão da bacia do Rio Itaqueri em sub-bacias de contribuição ......................... 72

Figura 14 - Médias anuais de percolação, escoamento superficial e evapotranspiração para as

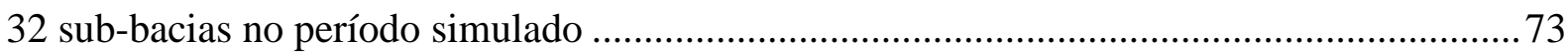

Figura 15 - Mapa de escoamento superficial para cada sub-bacia........................................ 74

Figura 16 - Mapa da produção de sedimentos para cada sub-bacia....................................... 75

Figura 17 - Variação espacial do pH nos afluentes do Reservatório do Lobo nos meses de

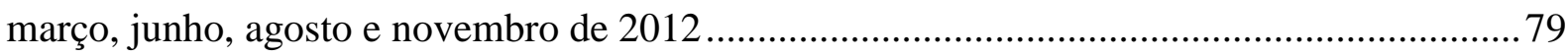

Figura 18 - Variação espacial do oxigênio dissolvido nos afluentes do Reservatório do Lobo nos meses de março, junho, agosto e novembro de 2012 80

Figura 19 - Variação espacial da temperatura nos afluentes do Reservatório do Lobo nos meses de março, junho, agosto e novembro de 2012

Figura 20 - Variação espacial da condutividade elétrica nos afluentes do Reservatório do Lobo nos meses de março, junho, agosto e novembro de 2012

Figura 21 - Variação espacial da turbidez nos afluentes do Reservatório do Lobo nos meses de março, junho, agosto e novembro de 2012 83

Figura 22 - Variação espacial dos sólidos em suspensão nos afluentes do Reservatório do Lobo nos meses de março, junho, agosto e novembro de 2012 
viii

Figura 23 - Frações de material em suspensão orgânico e inorgânico nos afluentes do Reservatório do Lobo nos meses de março, junho, agosto e novembro de 2012 85

Figura 24 - Análise de componentes principais realizada a partir dos dados de monitoramento de qualidade da água. Ordenação por estações de amostragem 86 Figura 25 - Vazão nas estações de amostragem do Rio Itaqueri e do Ribeirão do Lobo nos meses de março, junho, agosto e novembro de 2012 . 88 Figura 26 - Frações granulométricas do sedimento nos afluentes do Reservatório do Lobo nos meses de março e novembro de 2012 91 Figura 27 - Perfil longitudinal do percurso do Rio Itaqueri, com as respectivas estações de amostragem

Figura 28 - Perfil longitudinal do percurso do Ribeirão do Lobo, com as respectivas estações de amostragem 


\section{LISTA DE TABELAS}

Tabela 1 - Parâmetros relativos aos solos exigidos pelo SWAT …..........................................39

Tabela 2 - Dados climáticos mensais exigidos pelo SWAT …............................................... 44

Tabela 3 - Coeficientes de desagregação de chuvas de 24 horas de duração .......................... 46

Tabela 4 - Parâmetros de cobertura do solo e crescimento da vegetação ................................ 48

Tabela 5 - Associação entre as classes de uso e ocupação do solo da bacia e os tipos de cobertura do solo disponíveis no banco de dados do SWAT …........................................... 49

Tabela 6 - Variáveis limnológicas amostradas e métodos de determinação.............................55

Tabela 7 - Correspondência entre a antiga classificação de solos e a atual .............................64

Tabela 8 - Ocorrência das classes de uso e ocupação na bacia do Rio Itaqueri em 2010........69

Tabela 9 - Composição dos tipos de solo, cobertura e classes de declividade da sub-bacia de

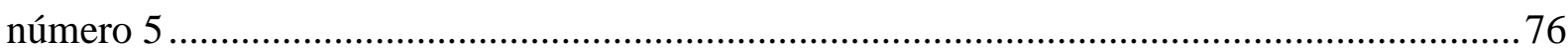

Tabela 10 - Composição dos tipos de solo, cobertura e classes de declividade da sub-bacia de

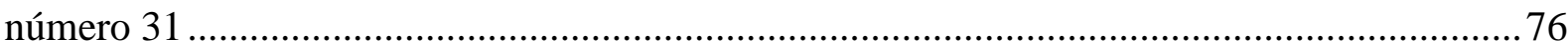

Tabela 11 - Quantidade total anual média de sedimentos produzida nas bacias dos principais contribuintes do Reservatório do Broa 78

Tabela 12 - Carga de sedimentos em suspensão das estações de amostragem do Rio Itaqueri e do Ribeirão do Lobo nos meses de março, junho, agosto e novembro de 2012 


\section{LISTA DE QUADROS}

Quadro 1 - Modelos perda de solo e de produção de sedimentos ……................................... 16

Quadro 2 - Compilação de alguns trabalhos utilizando o SWAT ........................................... 19

Quadro 3 - Classificação hidrológica do solo para as condições brasileiras e enquadramento

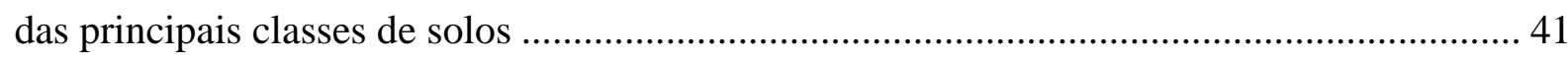

Quadro 4 - Caracterização das estações de amostragem nos afluentes do reservatório do Lobo 


\section{LISTA DE SIGLAS}

\begin{tabular}{|c|c|}
\hline $\mathrm{ACP}$ & Análise de componentes principais \\
\hline AGNPS & Agricultural Non-point Source Pollution Model \\
\hline APA & Área de Proteção Ambiental \\
\hline APHA & American Public Health Association \\
\hline CBERS & China-Brazil Earth-Resources Satellite \\
\hline $\mathrm{CE}$ & Condutividade elétrica \\
\hline CESP & Companhia Energética de São Paulo \\
\hline CETESB & Companhia de Tecnologia de Saneamento Ambiental \\
\hline $\mathrm{CN}$ & Curve Number \\
\hline CONAMA & Conselho Nacional do Meio Ambiente \\
\hline CPRM & Serviço Geológico do Brasil \\
\hline CREAMS & Chemicals, Runoff and Erosion from Agricultural Management Systems Model \\
\hline CRHEA & Centro de Recursos Hídricos e Ecologia Aplicada \\
\hline CSS & Carga de sedimentos em suspensão \\
\hline DEM & Digital Elevation Model \\
\hline EMBRAPA & Empresa Brasileira de Pesquisa Agropecuária \\
\hline EUPS & Equação Universal de Perdas de Solo \\
\hline HRU & Hydrologic Response Unit \\
\hline IAC & Instituto Agronômico de Campinas \\
\hline IGC & Instituto Geográfico e Cartográfico do Estado de São Paulo \\
\hline INPE & Instituto Nacional de Pesquisas Espaciais \\
\hline IPT & Instituto de Pesquisas Tecnológicas \\
\hline KINEROS & Kinematic Runoff and Erosion Model \\
\hline LISEM & Limburg Soil Erosion Model \\
\hline MEUPS & Equação Universal de Perda de Solo Modificada \\
\hline MSO & Material em suspensão orgânico \\
\hline MSI & Material em suspensão inorgânico \\
\hline MUSLE & Modified Universal Soil Loss Equation \\
\hline OD & Oxigênio dissolvido \\
\hline RUSLE & Revised Universal Soil Loss Equation \\
\hline SACERC & Central Elétrica de Rio Claro \\
\hline SCS & Soil Conservation Service \\
\hline SDR & Sediment delivery ratio \\
\hline SIG & Sistemas de Informação Geográfica \\
\hline
\end{tabular}


SPRING Sistema de Processamento de Informações Georreferenciadas

SST Sólidos suspensos totais

SWAT Soil and Water Assessment Tool

TEMP Temperatura

TIN Triangulated Irregular Network

TURB Turbidez

UGRHI Unidade de Gerenciamento de Recursos Hídricos

URH Unidade de Resposta Hidrológica

USLE Universal Soil Loss Equation

UTM Sistema Universal Transverso de Mercator

WEPP Water Erosion Prediction Project

WESP Watershed Erosion Simulation Program 


\section{SUMÁRIO}

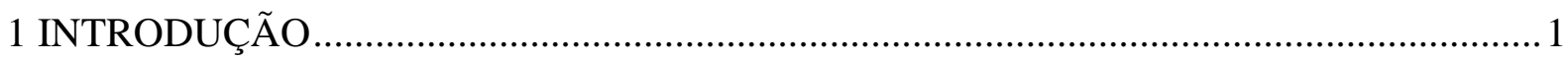

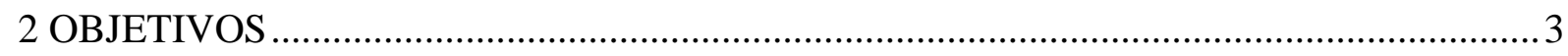

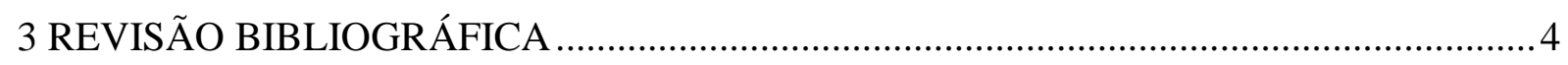

3.1 Impactos ambientais decorrentes de atividades antrópicas em bacias hidrográficas .......4

3.2 Dinâmica do processo erosivo e principais formas de atuação ....................................6

3.3 Produção de sedimentos em bacias hidrográficas ...................................................

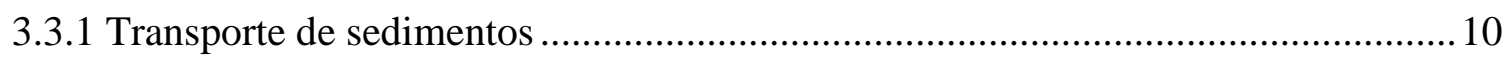

3.4 Modelos preditivos de perda de solo e de produção de sedimento ................................ 12

3.5 O modelo SWAT: características e aplicaçõos ........................................................ 17

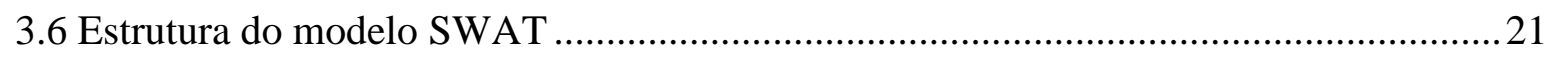

3.6.1 Balanço hídrico e modelagem hidrológica ...................................................... 21

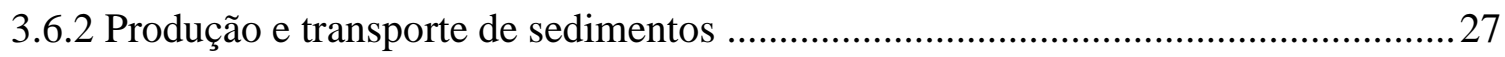

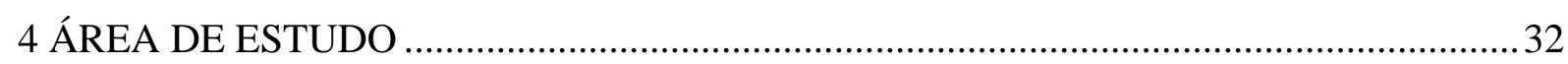

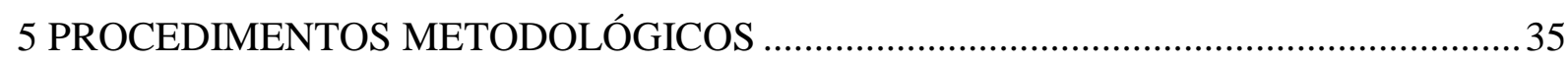

5.1 Preparação da base cartográfica e criação do banco de dados espacial.......................... 35

5.2 Obtenção de dados por meio de imagens de sensoriamento remoto .............................. 36

5.3 Modelagem da produção de sedimentos utilizando o simulador SWAT ....................... 37

5.3.1 Delineamento da bacia de drenagem e definição do número de sub-bacias ............ 38

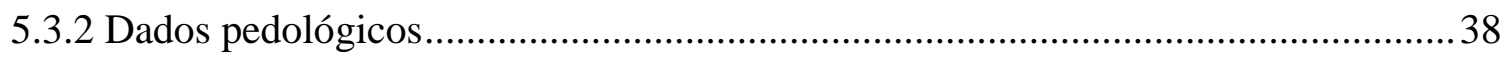

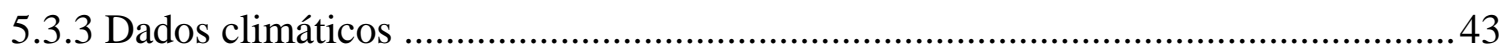

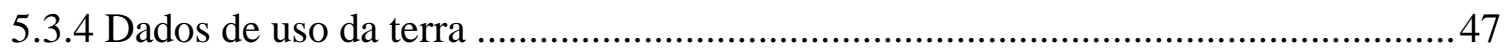

5.3.5 Definição das Unidades de Resposta Hidrológica (HRU)..................................... 49

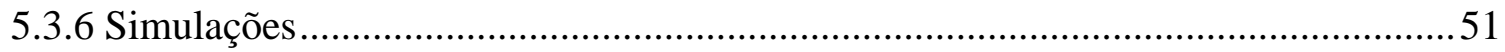

5.4 Monitoramento de variáveis nos cursos d'água da bacia .........................................52

5.5 Medição da vazão e determinação da carga sólida em suspensão..................................56 


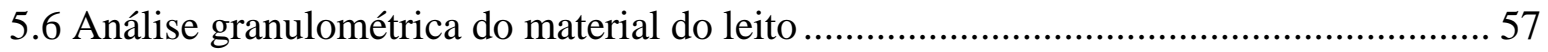

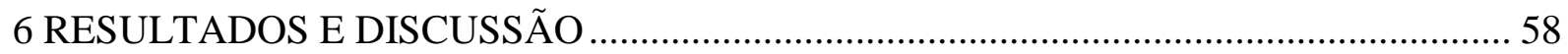

6.1 Caracterização do meio físico da bacia do Rio Itaqueri............................................... 58

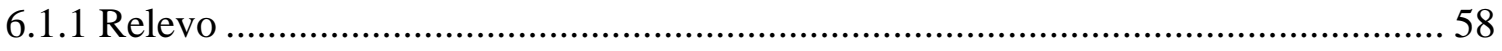

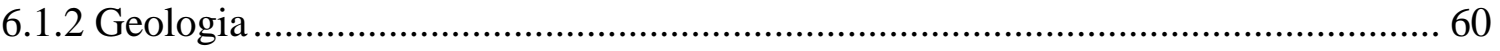

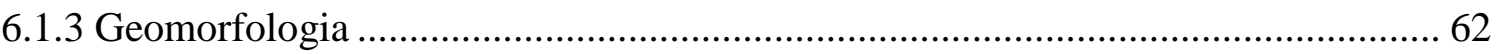

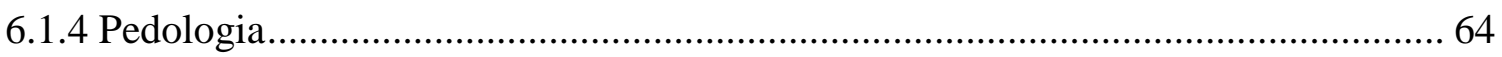

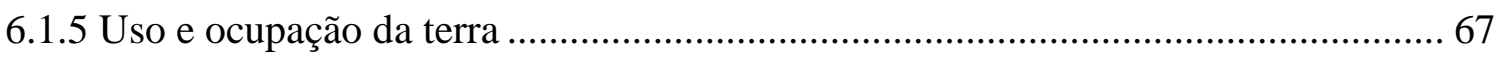

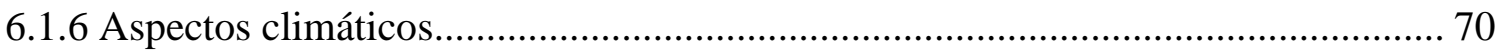

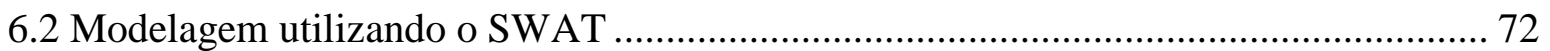

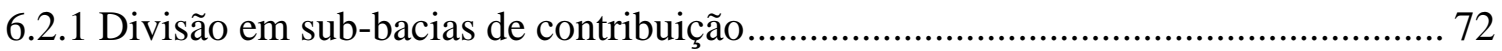

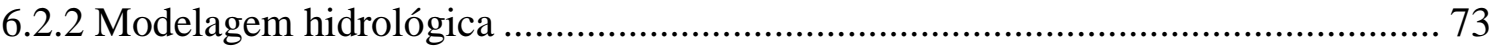

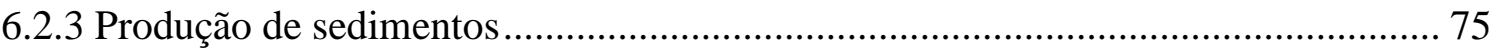

6.3 Monitoramento de parâmetros de qualidade da água.................................................. 78

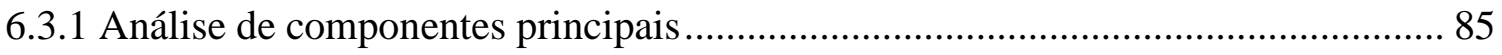

6.4 Vazão e descarga de sólidos em suspensão ........................................................... 87

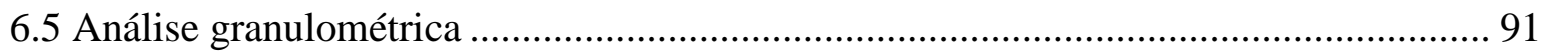

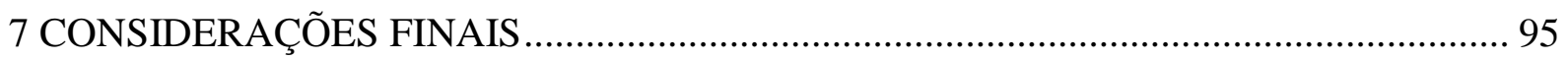

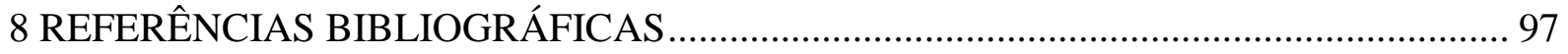




\section{INTRODUÇÃO}

O processo de ocupação do espaço, por meio da expansão dos núcleos urbanos e pelo avanço das atividades agropecuárias, se deu num período em que as informações técnicas eram pouco difundidas, não havendo a preocupação com a conservação do solo, das águas e de outros recursos naturais em grande parte dos territórios. Este modelo de ocupação acabou por ocasionar diversas pressões sobre o meio natural, desencadeando, dentre outros problemas, a redução da capacidade produtiva dos solos e a degradação dos recursos hídricos, tanto em termos qualitativos como quantitativos.

Nesse sentido, introduzidos no âmbito de utilização sustentável dos recursos naturais, têm crescido nas últimas décadas os estudos voltados ao planejamento conservacionista tanto do solo como da água, visando promover a recuperação e a preservação da qualidade dos recursos das bacias hidrográficas brasileiras.

Inserida neste contexto, a gestão dos recursos hídricos, cujo principal objetivo é garantir o suprimento de água em quantidade e qualidade suficientes para atender às necessidades da sociedade, deve ser conduzida de forma sistêmica, considerando as interações entre as intervenções antrópicas e o meio natural no âmbito das bacias hidrográficas (SCHUBART, 2000).

Desse modo, é de fundamental importância que as ações relacionadas ao manejo integrado dos recursos hídricos apresentem-se como um processo de desenvolvimento coordenado, que envolva o gerenciamento das águas articulado às ações de planejamento e ordenamento do uso do solo, tendo como principal objetivo a integração de aspectos técnicos, econômicos, sociais e ambientais.

Muitas vezes, são exercidas determinadas atividades sobre o solo sem que este tenha capacidade de suportar tais ações, o que dá origem aos denominados conflitos de uso da terra. Culturas agrícolas, pastagens, ocupações urbanas e desmatamento, quando realizados em áreas impróprias, como em elevadas declividades e em topos de morros, são exemplos de conflitos (RUHOFF, 2004). Esses fatores acabam favorecendo a instalação de processos de erosão do solo, que, dentre outros inúmeros problemas, conferem uma maior carga sedimentar ao fluxo de água nos canais fluviais e reservatórios.

Carvalho (2008) enumera vários impactos negativos decorrentes do aporte de sedimentos no meio aquático. Dentre os principais, pode-se citar a alteração da qualidade da água, visto que os sedimentos atuam como portadores de poluentes, a redução das atividades 
fotossintéticas, devido ao aumento da turbidez, e as alterações na biota aquática. Quando o aporte de sedimentos se dá em reservatórios de acumulação podem ocorrer ainda processos de assoreamento, com a consequente redução do volume de água e da vida útil do lago, o aumento dos riscos de enchente e a impossibilidade de navegação, além de estarem sujeitos aos impactos citados anteriormente.

Ainda existe uma grande dificuldade de compreender e quantificar os fenômenos ligados à erosão e produção de sedimentos devido às inúmeras variáveis que influenciam estes processos. Segundo Grando (2011), a caracterização destes fenômenos depende do conhecimento dos principais atributos responsáveis por intervir na dinâmica dos processos erosivos, tais como: tipo de solo, características mecânicas, físicas e hídricas do solo, cobertura vegetal, precipitação, práticas de manejo, dentre outras. Por sua vez, essas variáveis vêm sendo compreendidas por meio da multidisciplinaridade de diversas áreas do conhecimento correlacionadas com as questões ambientais, as quais procuram quantificar estes fenômenos através de diferentes técnicas de monitoramento, experimentação e modelagem.

Visando contribuir com estes estudos, esta pesquisa propôs-se a realizar um diagnóstico da produção de sedimentos e de seu transporte na bacia hidrográfica do Rio Itaqueri, localizada entre os municípios de Itirapina e Brotas, estado de São Paulo, de maneira a compreender a dinâmica destes processos e identificar as principais áreas responsáveis pelo aporte de sedimentos na rede de drenagem.

Tendo em vista a multiplicidade de fatores ambientais e antrópicos envolvidos no processo erosivo hídrico, neste estudo optou-se por utilizar o simulador Soil and Water Assessment Tool (SWAT) para estimar a produção de sedimentos na bacia. Desenvolvido pela Agricultural Research Service e pela Texas A\&M University, o SWAT é um modelo de base física, o qual considera em seu processo de modelagem informações referentes às características hidrológicas, clima, solo e uso da terra, tendo sua interface acoplada a um Sistema de Informação Geográfica.

Tendo ciência dos impactos ambientais derivados do aporte de sedimentos em canais fluviais, este estudo inclui ainda aspectos relacionados à qualidade da água e ao sedimento dos cursos d'água da bacia. Desse modo, realizou-se o monitoramento de parâmetros de qualidade da água e determinação da granulometria do sedimento de fundo de dez seções de amostragem, visando reunir elementos de análise que possam contribuir para uma melhor compreensão a respeito da dinâmica hidrossedimentológica da bacia. 


\section{OBJETIVOS}

Esta pesquisa teve como objetivo a realização de um diagnóstico sedimentológico da bacia hidrográfica do Rio Itaqueri - localizada entre os municípios de Itirapina e Brotas - SP, considerando as etapas de produção de sedimentos e seu transporte nos cursos d'água da bacia. Para realização de tal objetivo, foram utilizadas ferramentas de modelagem ambiental associadas a Sistemas de Informação Geográfica, bem como foi realizado o monitoramento de variáveis limnológicas e hidrossedimentológicas relacionadas a tais processos nos principais cursos d'água da bacia.

Os objetivos específicos deste trabalho consistem em:

- Identificar as áreas da bacia que contribuem significativamente para a produção de sedimentos utilizando as ferramentas disponíveis no simulador SWAT;

- Avaliar características relacionadas aos sedimentos nos canais fluviais da bacia por meio da determinação de parâmetros físico-químicos de qualidade da água e de análise granulométrica do material de fundo;

- Verificar a existência de relações entre os resultados gerados pelo simulador e as variáveis caracterizadas experimentalmente, buscando compreender a dinâmica dos sedimentos na bacia. 


\section{REVISÃO BIBLIOGRÁFICA}

\subsection{Impactos ambientais decorrentes de atividades antrópicas em bacias hidrográficas}

A interação do homem com o meio físico-natural resulta em diversas alterações ambientais, tanto de forma harmônica como provocando sérias modificações que acabam por comprometer a qualidade ambiental e, consequentemente, a qualidade de vida (CUNICO e OKA-FIORI, 2008). Tais alterações no meio podem ser caracterizadas sob a forma de impacto ambiental, definido por Sánchez (2006) como qualquer alteração da qualidade ambiental que resulta da modificação de processos naturais ou sociais provocada por uma ação humana.

Considerando-se a bacia hidrográfica como recorte de análise, uma das atividades potencialmente geradoras de impactos ambientais é a atividade agropecuária. A expansão das fronteiras agrícolas e pastagens é, em grande parte, responsável por impactos como desmatamento, queimadas em florestas e áreas de vegetação nativa, poluição por dejetos animais e agrotóxicos, erosão e degradação de solos, contaminação das águas, dentre outros (FIRMINO e FONSECA, 2008).

De acordo com Toledo (2001), as constantes mudanças no uso e cobertura da terra resultantes da agropecuária provocam alterações significativas no balanço de água do solo, com reflexos tanto em suas camadas superficiais quanto nas subsuperficiais, resultando em erosão e transporte de sedimentos e causando desta forma diversas modificações nos ecossistemas terrestres e aquáticos.

Além disso, os desmatamentos, a expansão de loteamentos em áreas impróprias, a ausência de práticas de conservação do solo e a não realização de obras com vistas ao disciplinamento das águas pluviais são alguns dos fatores que têm ação significativa na multiplicação dos processos erosivos (KERTZMAN et al., 1991).

Os processos erosivos, se não controlados, tendem a evoluir e causar prejuízos não somente ambientais, mas também de ordem econômica e social. Segundo Dechen e Prochnow (2003), o impacto da erosão no solo pode comprometer a sustentabilidade do sistema agrícola, exigindo a aplicação de altas tecnologias para manter a produtividade das culturas. Como consequência desse processo, torna-se necessário o aumento da aplicação de fertilizantes, aumentando os custos de produção. 
Em certos tipos de solos, quando a erosão atinge um elevado grau de desgaste, causa a inutilização de áreas de cultivo, não só pelo desgaste da camada superficial, mas também pelas voçorocas, em vários estágios de profundidade, que impedem a continuidade de uma exploração econômica (RIO GRANDE DO SUL, 1985). Além disso, a presença de erosões de grande porte impossibilita a utilização do solo para diversos outros usos devido às alterações na topografia, podendo chegar a inviabilizar obras civis e até mesmo gerar áreas de risco.

A ocorrência de assoreamento em corpos d'água encontra-se intimamente relacionada aos processos erosivos, uma vez que estes processos fornecem os materiais que darão origem ao assoreamento. Quando não há mais energia suficiente para transportar o material erodido, este material é depositado, ocasionando o acúmulo permanente de sedimentos no leito dos cursos d'água. (GUERRA, 1995).

Dependendo do tipo de sedimento proveniente das áreas erodidas, o impacto qualitativo nos cursos de água pode se manifestar tanto através do aumento da sua turbidez, que diminui a luminosidade da água e causa problemas à fauna e flora aquática, como por meio do aumento da concentração de nutrientes, patógenos e metais pesados, visto que os sedimentos podem atuar como portadores desses elementos (NOVOTNY e OLEM, 1993). Além disso, o aumento da turbidez pode ocasionar a redução das atividades fotossintéticas, alterando a produtividade do sistema aquático.

Quando o aporte de sedimentos ocorre em reservatórios de acumulação, podem ocorrer ainda processos de assoreamento com a consequente redução do volume de água e da vida útil do lago, além do aumento dos riscos de enchente e a impossibilidade de navegação. Além disso, estes corpos d'água também estão sujeitos aos impactos qualitativos anteriormente descritos.

Segundo Grossi (2006), um outro fator de degradação associado às praticas agropecuárias é o aumento do uso de fertilizantes, o qual altera a composição química do solo. O uso contínuo de herbicidas na agricultura pode ocasionar o seu acúmulo, podendo eventualmente afetar ou mesmo exterminar os microorganismos ali existentes. O perigo tornase maior quando são usados diversos produtos, os quais, aplicados em doses excessivas, destroem outros vegetais além das espécies invasoras. Com a ocorrência das chuvas, estes produtos são carreados para os córregos, rios e lagos, além de atingir também as águas subterrâneas.

Novotny e Olem (1993) argumentam que a criação de animais é outra atividade que pode impactar o meio de diversas maneiras. Uma criação confinada produz uma carga do tipo pontual, enquanto criações em pastagens convencionais geram uma carga de poluição difusa 
que será carreada pelas águas das chuvas. Além disso, a movimentação dos animais no pasto interfere na compactação do solo, diminuindo a capacidade de infiltração de água, além de criar caminhos preferenciais de escoamento, podendo dar origem a sulcos e ravinas.

O processo de urbanização também é responsável pela inserção de diversos fatores de degradação, muitas vezes relacionados aos fatores já abordados. Segundo Cunico (2007), podem ser citados como consequência da antropização: a impermeabilização do solo, resultando em maiores incidências de inundações; a ocupação de encostas com loteamentos e edificações, aumentando o risco de deslizamentos; a canalização e retificação dos canais fluviais; a ocorrência de depósitos de lixo em locais impróprios; a invasão das áreas periféricas com a instalação de favelas e, por fim, a implantação de obras públicas mal dimensionadas, ocasionando rompimento de canais pluviais, de galerias de esgoto, de pontes, entre outros (OLIVEIRA e HERRMANN, 2001).

Outro problema relacionado ao processo de urbanização refere-se à retirada da vegetação, que reflete diretamente no microclima, na fauna, na proteção do solo e na rede de drenagem. Salomão e Iwasa (1999) apontam que, com a ampliação das áreas construídas e pavimentadas, ocorre um aumento considerável no volume e na velocidade das enxurradas, acelerando o desenvolvimento de erosões de grande porte em áreas periurbanas.

Diante do cenário exposto, verifica-se que a degradação dos recursos naturais, principalmente do solo e da água, vem crescendo de forma significativa. Esse crescimento reflete-se no assoreamento de nascentes e cursos de água, na destruição de estradas, pontes e bueiros, na disponibilidade escassa de água para a irrigação e abastecimento, na redução da produtividade agrícola, na diminuição da renda líquida dos moradores e, consequentemente, no empobrecimento da sociedade local, com reflexos danosos para a economia (BERTONI e LOMBARDI NETO, 2005).

\subsection{Dinâmica do processo erosivo e principais formas de atuação}

A erosão pode ser definida como o processo de desagregação e remoção de partículas do solo ou fragmentos de rocha, que são removidos, transportados e depositados pela ação combinada de agentes como vento, água, gelo, gravidade ou organismos (FENDRICH et al., 1997). É um fenômeno complexo que depende das condições hidrológicas, da temperatura, da cobertura vegetal, das propriedades do solo, da topografia do terreno, dentre outros fatores (CUNHA e SANTOS, 1985). 
Quando atuante de forma natural, o processo erosivo é um dos principais responsáveis pela evolução da superfície terrestre, permitindo a construção e a modelagem das formas do relevo por meio de processos denudacionais. Tal fenômeno ocorre de forma lenta e contínua, sendo por tal motivo denominado erosão geológica (SALOMÃO e IWASA, 1995).

Entretanto, sabe-se que muitas atividades antrópicas modificadoras do meio podem contribuir potencialmente para a aceleração dos processos erosivos, tais como o desmatamento, as atividades agropecuárias e a expansão das áreas urbanizadas. Desse modo, o processo de erosão é dito acelerado quando esse é mais rápido do que os processos de formação do solo, não permitindo que este se regenere, o que acaba gerando um desequilíbrio entre as fases de erosão natural e sedimentação (CPTI, 1998).

Dentre os vários agentes responsáveis pelo processo de desagregação e transporte de partículas, podem-se citar como principais a água (erosão hídrica) e os ventos (erosão eólica). No Brasil, devido às condições climáticas e as características dos solos, a erosão hídrica é considerada como o tipo de erosão responsável por causar os maiores prejuízos (FERREIRA, 1981).

A erosão hídrica consiste fundamentalmente no transporte de partículas de solo pela ação das águas, por meio do processo de arrastamento. Existem várias formas de erosão causadas pelas águas, tendo maior importância a erosão através das chuvas (erosão pluvial) e a erosão nas encostas marginais dos rios (erosão fluvial).

A erosão pelo escoamento das águas pluviais está diretamente ligada à intensidade da chuva, a qual é expressa pela quantidade de precipitação em um determinado espaço de tempo. Conforme expõe Guerra (1999), a dinâmica erosiva começa com o impacto das gotas nos solos, em um efeito conhecido como splash ou salpicamento, que causa a ruptura dos agregados e desagregação de partículas. Com a continuação da chuva, ocorre a formação de poças à medida que o solo torna-se saturado, ocasionando o fenômeno denominado selamento, ou seja, há uma redução do efeito splash, porém há o aumento do escoamento superficial ou runoff. Desse modo, a água começa a escoar na superfície, primeiramente em lençol, e depois através de fluxos lineares, promovendo o arraste das partículas desagregadas.

A erosão causada pelas chuvas pode se manifestar de diferentes formas, sendo classificada por diversos autores em dois tipos principais: erosão laminar, também denominada por alguns autores como erosão superficial em lençol e erosão linear, também conhecida como erosão por fluxo concentrado.

Segundo Ferreira (1981), a erosão laminar caracteriza-se por um desgaste que ocorre em camadas, onde há a remoção de poucos milímetros de solo a cada evento chuvoso, sendo esta 
paralela à superfície do terreno, e, por isso, não sendo notada durante muitos anos. Entretanto, com o tempo, começam a ficarem expostas na superfície do solo pedras que antes estavam enterradas e raízes de árvores que outrora se apresentavam cobertas, dentre outros sinais que evidenciam a perda de solo. Devido ao seu difícil diagnóstico, a erosão laminar é talvez a mais grave e prejudicial forma de erosão, sendo também o ponto de partida para instalação de processos erosivos lineares.

Os processos de erosão linear são caracterizados por um conjunto de feições erosivas causadas pela concentração de linhas de fluxo das águas de escoamento superficial, podendo estas serem classificadas em sulcos, ravinas ou voçorocas.

Segundo Guerra (1999), os sulcos constituem uma forma de erosão que se apresenta como pequenas incisões na superfície terrestre em forma de filetes rasos, perpendiculares às curvas de nível. Geralmente, tal feição apresenta profundidade e largura inferiores a cinquenta centímetros, tendo em suas bordas pequena ruptura na superfície do terreno.

A erosão em ravina ocorre principalmente quando há concentração de fluxos d’água em determinados pontos, provocando o aprofundamento dos sulcos e formando canaletas bem definidas (REGO, 1987). É considerada uma forma erosiva de grande porte, apresentando largura superior a um metro e profundidade superior a 0,5 metros, onde a feição das bordas é abrupta, ocasionando rupturas instáveis na superfície do terreno (GUIMARÃES et al., 2008).

Já as voçorocas constituem feições de erosão mais complexas e destrutivas no quadro evolutivo da erosão linear, sendo originadas por dois tipos de escoamento que podem atuar em conjunto ou separadamente: o superficial e o subsuperficial (SOUZA, 2001). As águas superficiais são responsáveis pelo aparecimento das voçorocas, enquanto que à água subsuperficial cabe a responsabilidade de desencadear o avanço lateral destas, através de várias formas de atuação, inclusive pelo arraste de partículas do maciço (RODRIGUES e VILAR, 1984).

A presença do lençol freático, interceptado pela voçoroca, induz ao aparecimento de surgências d'água, acarretando o fenômeno conhecido como "piping" (erosão interna que provoca a remoção de partículas do interior do solo, formando "tubos" vazios que provocam colapsos e escorregamentos laterais do terreno, alargando a voçoroca, ou criando novos ramos). Além deste mecanismo, as surgências d'água nos pés dos taludes da voçoroca provocam sua instabilização e descalçamento. Sendo assim, as voçorocas se caracterizam por terem uma cabeceira e diferentes ressaltos ao longo de seu curso, sendo consideradas formas de paisagens instáveis (SOUZA, 2001). 


\subsection{Produção de sedimentos em bacias hidrográficas}

Carvalho (2008) define sedimento como a partícula derivada da rocha ou de materiais biológicos por processos físicos ou químicos, que é transportada pela água ou pelo vento do lugar de origem aos rios e locais de deposição. Segundo o autor, os processos responsáveis pela sedimentação são muito complexos, abrangendo erosão, deslocamento das partículas por enxurradas ou outros meios até os rios, transporte do sedimento nos cursos d'água, deposição do sedimento na calha dos rios, lagos e reservatórios e sua compactação.

A produção de sedimentos pode ser entendida como a quantidade de partículas erodidas que são transportadas pelo curso d'água. Tal produção acontece através da associação de eventos naturais e antrópicos que, associados a diversas variáveis, têm maior ou menor produção por área. A produção de sedimentos pode ser expressa em metros cúbicos ou em toneladas, quando referida à área da bacia, podendo ser também expressa como produção específica, em $\mathrm{m}^{3} / \mathrm{km}^{2} /$ ano ou $\mathrm{t} / \mathrm{km}^{2} /$ ano (PEREIRA, 2010).

De acordo com Walling (1990), o termo produção de sedimentos representa apenas uma parcela do total de sedimentos produzidos em uma bacia hidrográfica em decorrência dos processos erosivos atuantes, visto que uma quantidade significativa de material erodido é depositada ao longo das vertentes, não sendo, portanto, removida da bacia de drenagem. Em vista disso, alguns autores defendem o uso do termo fornecimento de sedimentos para referirse à parcela do material que atinge o exutório, ao invés de produção de sedimentos.

Bordas e Semmelmann (2001) citam que a produção de sedimentos em uma bacia pode ser dividida em três grandes compartimentos: os interflúvios ou vertentes, que constituem a área de captação e produção de sedimentos; os leitos ou calhas, em que se concentra o escoamento e que têm por papel principal realizar a propagação dos sedimentos produzidos pelos interflúvios até a saída da bacia; e as planícies aluviais ou várzeas, que circulam as calhas e que funcionam como receptores dos sedimentos produzidos mais a montante.

De forma geral, nas porções elevadas de uma bacia hidrográfica há maior erosão e transporte de sedimentos, devido principalmente à acentuada declividade dessas áreas, que acaba por gerar maiores velocidades de escoamento (KRAMER e MEYER, 1969). A erosão vai diminuindo da alta para a média bacia, na medida em que as declividades decrescem e as chuvas se tornam menos intensas, fora das regiões montanhosas. Na parte baixa da bacia, há muita formação de depósitos sedimentares, isto é, a maior parte dos sedimentos erodidos se distribui pelos terrenos (FOSTER, 1982). 


\subsubsection{Transporte de sedimentos}

Os processos hidrossedimentológicos estão intimamente vinculados ao ciclo hidrológico e compreendem as etapas de deslocamento, transporte e deposição de partículas sólidas presentes na superfície da bacia hidrográfica (Silva et al., 2003).

No ciclo hidrossedimentológico, os materiais resultantes do processo de erosão acabam sendo transportados principalmente pela ação das águas de escoamento superficial, sendo tal transporte influenciado pelas condições topográficas do local e pela granulometria dos materiais carreados. O transporte desse material arrancado se dá por fluxo de massa, podendo ocorrer na forma de rolamento e arraste da partícula, ou então por suspensão (VESTANA, 2008).

Segundo Carvalho (2008), o processo de deposição ocorre quando a força do escoamento se reduz até a condição de não poder continuar a deslocar a partícula. O depósito dos sedimentos geralmente se dá em locais relativamente mais baixos, podendo ocorrer em depressões naturais do terreno ou mesmo em encostas de declividade mais suave. Além disso, o material pode adentrar a rede de drenagem, sendo transportado pelos cursos d'água até o oceano ou ficar retido em reservatórios, nas margens de cheia, em planícies de inundação, deltas e estuários.

Além disso, alguns sedimentos transportados podem ainda ser depositados em determinados locais apenas temporariamente, pois eventos subsequentes podem ressuspendêlos e movimentá-los novamente através do sistema de transporte (FOSTER, 1982).

A parcela de sedimentos que é depositada nos declives, nas saliências dos terrenos ou nas planícies, não alcançando o curso d'água, é representada através da taxa de entrega de sedimento (ou sediment delivery ratio - SDR). Esta é definida como um parâmetro de escala adimensional que representa a relação entre a produção de sedimentos no exutório da bacia e a erosão bruta, que representa a soma de todo o sedimento desagregado por todas as formas de erosão que ocorrem dentro da bacia (WALLING, 1983).

Ainda segundo Walling (1983), a magnitude da taxa de entrega de sedimentos para uma determinada bacia é influenciada pela variação dos fatores geomorfológicos e ambientais, incluindo natureza, extensão e localização das fontes de sedimento, relevo e características do declive, padrão de drenagem e hidráulica dos canais, cobertura vegetal, uso do solo, textura e estrutura do solo.

Segundo Carvalho (2008), os sedimentos que chegam ao curso d'água apresentam diversas formas, tamanhos e pesos, sendo submetidos a um processo de transporte 
diferenciado, de acordo com as condições do local e do escoamento. De acordo com o autor, o transporte nos canais pode ocorrer de três maneiras:

Carga sólida de arrasto - são as partículas de sedimento que rolam ou escorregam longitudinalmente no curso d'água. As partículas estão em contato com o leito praticamente todo o tempo.

Carga sólida saltante - são as partículas que pulam ao longo do curso d'água por efeito da correnteza ou devido ao impacto de outras partículas.

Carga sólida em suspensão - são as partículas que estão suportadas pelas componentes verticais das velocidades do fluxo turbulento, enquanto estão sendo transportadas pelas componentes horizontais dessas velocidades, sendo pequenas suficientemente para permanecerem em suspensão.

Os materiais de arraste e saltação constituem o material do leito e têm seu movimento governado pela capacidade de transporte do escoamento. Por outro lado, o material em suspensão, compreendendo as partículas de granulometria reduzida (silte e argila), move-se aproximadamente na mesma velocidade da corrente (NORDIN e McQUIVEY, 1971).

Dentre o material particulado carregado em suspensão, os sedimentos mais finos, que compreendem as frações das classes silte e argila, possuem um padrão da velocidade de deposição distinto com relação a outros grãos maiores, sendo influenciado por fatores intrínsecos como a salinidade, a própria concentração de sedimentos e a matéria orgânica na coluna d' água, além da própria composição mineralógica (SOLOMONS e FORSTNER, 1984; KRONE, 1962; LICK et al., 1992).

Ward e Trimble (1995) afirmam que a carga em suspensão pode representar mais de 90\% do material total transportado. As partículas de granulometria maior, como as areias e cascalhos, são roladas, deslizadas ou saltam ao longo do leito dos rios. Tal porcentagem também é descrita por Carvalho (2008), ao considerar que a carga em suspensão é predominantemente maior que a do fundo no alto curso (90\% a 95\%).

Além das formas de transporte sólido apresentadas, existe uma parcela de material que é transportada dissolvida no curso d'água, movimentando-se na mesma velocidade do fluxo. A carga dissolvida compreende basicamente os constituintes intemperizados das rochas que são transportados em solução química pelas águas fluviais e subterrâneas.

A proporção entre os materiais dissolvidos e materiais particulados varia entre os diferentes cursos d'água. Christofoletti (1981) cita que, para os rios brasileiros, a carga particulada geralmente é bem maior que a carga dissolvida. Além disso, o autor discorre que a 
composição química das águas fluviais varia de acordo com a litologia, a vegetação e a utilização do solo da bacia hidrográfica.

O somatório das parcelas de sedimentos carregadas em suspensão e formas de leito com a carga em solução corresponde à carga total de sedimentos transportada pelo curso d'água. A carga total de sedimentos é, em última análise, composta por materiais fornecidos tanto por processos químicos, por processos pluviais e por movimentos de arraste de massa nas vertentes. A Figura 1 ilustra os processos atuantes nesse sistema.

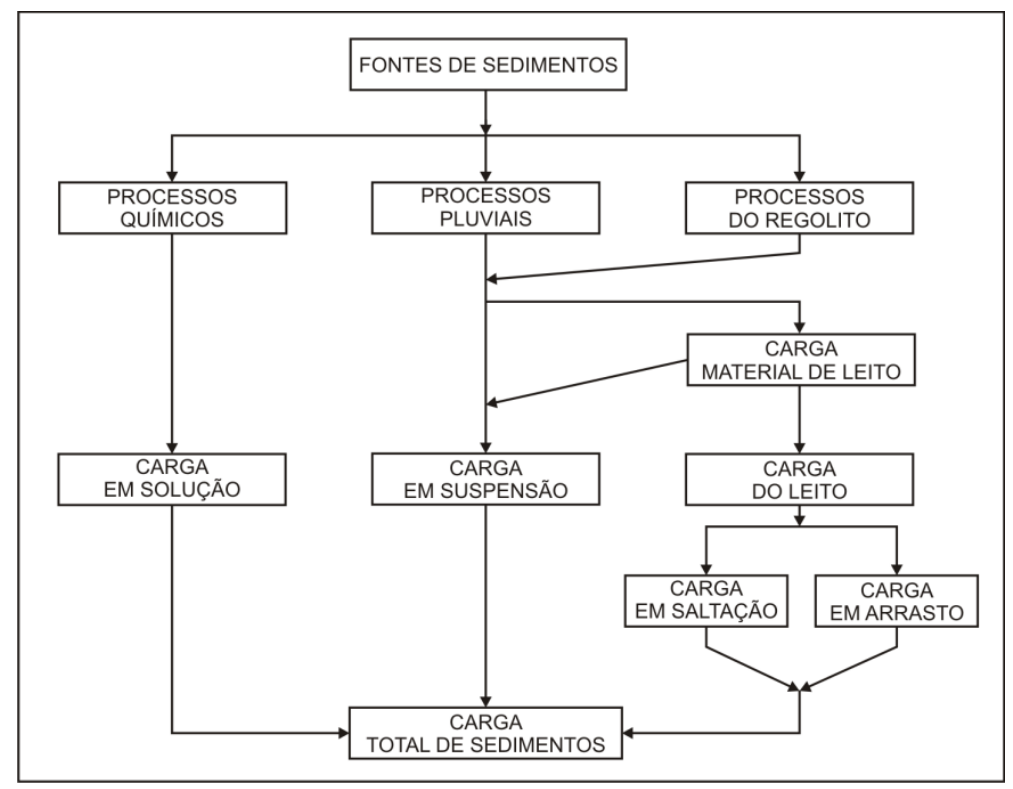

Figura 1 - Processos atuantes no transporte de sedimentos. Fonte: Christofoletti (1981)

Segundo Silva et al. (2003), é importante ressaltar que a maior parte destas considerações é válida principalmente para bacias com pouco índice de degradação, pois se houver superexploração do solo e dos recursos hídricos de uma bacia, seu regime fuvial, bem como o regime hidrossedimentológico, podem apresentar-se completamente distorcidos em relação a seu regime natural.

\subsection{Modelos preditivos de perda de solo e de produção de sedimento}

Segundo Reichardt e Timm (2004), muitas vezes a determinação da perda de solo e da produção de sedimentos através de métodos diretos em campo é um processo moroso e caro, sendo essa uma das principais justificativas do crescente interesse dos pesquisadores pelos modelos de predição da erosão. 
Paiva (2003) afirma que os modelos preditivos podem ser classificados, quanto à sua estrutura, em empíricos e conceituais. Os modelos empíricos utilizam relações matemáticas baseadas em observações, sendo mais simples e pouco robustos, uma vez que são concebidos a partir de condições específicas. Desse modo, não permitem realizar simulações em condições para os quais o modelo não previu, tais como, chuvas extremamente altas, mudança de uso do solo, dentre outras (RENNÓ e SOARES, 2000).

Já os modelos conceituais são baseados em processos físicos, procurando descrever as etapas que envolvem determinado fenômeno estudado. São modelos mais complexos, geralmente aplicados na escala de bacia hidrográfica ou de vertente, requerendo uma maior quantidade de dados de entrada e um maior refinamento destas informações.

Os modelos podem também ser classificados em relação à escala temporal em que operam, sendo agrupados em contínuos ou discretos: os primeiros buscam representar longos períodos da série, muitas vezes contemplando épocas de comportamentos hidrológicos diferentes, enquanto os segundos objetivam modelar períodos isolados (BREDA, 2008).

Além disso, os modelos ainda podem ser classificados em concentrados ou distribuídos. No primeiro caso, os parâmetros variam somente em função do tempo e são representados por equações com uma variável independente, enquanto no segundo podem variar também em relação ao espaço geográfico, utilizando-se para sua representação equações com mais de uma variável independente (MORO, 2005).

Dentre os modelos preditivos de erosão hídrica, a Equação Universal de Perda de Solo EUPS (ou USLE - Universal Soil Loss Equation), proposta por Wischmeier e Smith (1978), é um dos mais aceitos e utilizados, apresentando grande aplicabilidade em várias partes do mundo. Tal modelo foi estabelecido com base em mais de 10.000 parcelas experimentais estudadas nos Estados Unidos, com distintas características de solo, clima, relevo e cultivos. A ULSE estima a perda de solo por erosão do tipo laminar através da multiplicação de seis fatores, conforme apresentados na equação 1:

$\mathrm{A}=\mathrm{R} \cdot \mathrm{K} \cdot \mathrm{L} \cdot \mathrm{S} \cdot \mathrm{C} \cdot \mathrm{P}$

Onde:

$\mathrm{A}=$ estimativa média anual de perda de solo (t/ha/ano);

$\mathrm{R}$ = fator de erosividade das chuvas (MJ.mm/ha.h);

$\mathrm{K}$ = fator de erodibilidade do solo (t.h/MJ.mm);

$\mathrm{L}=$ comprimento da vertente $(\mathrm{m})$; 
$\mathrm{S}=$ declividade da vertente $(\%)$

$\mathrm{C}=$ fator de cobertura, uso/manejo (adimensional);

$\mathrm{P}=$ fator de práticas conservacionistas (adimensional).

Na equação, o fator $\mathrm{R}$, erosividade da chuva, é definido como um índice numérico que expressa a capacidade da chuva de erodir o solo de um terreno sem cobertura vegetal em termos de sua energia cinética. A erosividade é função das características físicas das chuvas, como duração, quantidade, intensidade, dentre outras (HUDSON, 1973).

$\mathrm{O}$ fator $\mathrm{K}$, erodibilidade do solo, busca evidenciar a facilidade com que determinado solo erode, a partir do impacto da chuva e/ou do escoamento superficial, sendo, portanto, estimado a partir das características intrínsecas ao tipo de solo e de suas propriedades físicas (BERTONI e LOMBARDI NETO, 2005).

Os fatores comprimento de vertente (L) e grau do declive $(\mathrm{S})$ influem diretamente sobre a velocidade do escoamento superficial e, consequentemente, sobre a perda de solo por erosão. Geralmente tais fatores são trabalhados simultaneamente, originando $\mathrm{o}$ fator topográfico LS (WISCHMEIER e SMITH, 1978).

O fator C, uso e manejo do solo, expressa a relação esperada entre perdas de solos em áreas com diferentes tipos de uso/cobertura e áreas continuamente descobertas, ambas submetidas às mesmas condições de declividade e de precipitação. Já o fator prática conservacionista $\mathrm{P}$ expressa a relação entre a perda de solo esperada em uma cultura submetida a uma determinada prática conservacionista e a perda que ocorreria mantendo-se as mesmas condições, porém sem a adoção de medidas de conservação (plantio morro abaixo). Práticas de conservação do solo comumente consideradas na aplicação da USLE incluem o plantio em contorno, o terraceamento e a alternância de culturas.

Silva (2006) explicita que apesar de amplamente difundida, a USLE apresenta algumas limitações quanto à sua utilização, como a não estimativa dos processos de deposição e transporte de sedimentos que, frequentemente, ocorrem ao longo da vertente devido à complexidade do relevo das bacias hidrográficas. Além disso, os parâmetros que envolvem os processos hidrológicos e seus efeitos estão apenas implícitos na equação, como o efeito do escoamento superficial no processo erosivo, não sendo diretamente trabalhados.

Segundo Fujihara (2002), devido as limitações apresentadas pelo modelo original, a USLE vem sofrendo modificações (MUSLE) e revisões (RUSLE). A MUSLE (Modified Universal Soil Loss Equation), proposta por Williams (1975), substitui o fator de erosividade 
da chuva por um fator de escoamento superficial, permitindo-se estimar a produção de sedimentos no exutório de uma bacia decorrente de eventos de chuva isolados.

Já a RUSLE (Revised Universal Soil Loss Equation), ainda que de concepção empírica, é um modelo que se vale de algoritmos computacionais para realização dos cálculos. Dentre as melhorias em relação ao modelo original, pode-se citar a utilização de novos algoritmos para calcular o comprimento de vertente e a declividade (LS), bem como a capacidade de calcular tal fator para vertentes de variadas formas. Tal revisão do modelo também considera a sazonalidade das chuvas durante o ano, o que permite considerar a variabilidade do fator de erodibilidade para o período de simulação (CECCHIA, 2005).

Apesar de serem frequentemente utilizados, os modelos baseados na USLE geralmente não são suficientes para compreender os processos hidrossedimentológicos que ocorrem nas bacias hidrográficas. Desse modo, foram desenvolvidos modelos mais complexos, de estrutura conceitual, englobando não somente a modelagem da perda de solo, mas também etapas de modelagem hidrológica, geradores climáticos, ciclos de cultura, dentre outros. No Quadro 1 estão compilados alguns dos modelos mais utilizados atualmente, bem como são apresentadas algumas de suas principais características.

Modelos como o CREAMS (Chemicals, Runoff and Erosion from Agricultural Management Systems Model) e o WEPP (Water Erosion Prediction Project) usam simulação contínua para modelar a produção de escoamento superficial, o que requer grande quantidade de informações relacionadas ao clima e ao uso do solo associados às condições em estudo. Além disso, são sensíveis à evapotranspiração e à dinâmica do solo, simulando uma grande quantidade de pequenos eventos que podem não produzir escoamento superficial e perdas de solo expressivas (MORGAN et al., 1998 apud PRUSKI et al., 2001).

O modelo KINEROS (Kinematic Runoff and Erosion Model), segundo Silva e Santos (2008), é um modelo hidrossedimentológico cinemático, distribuído e de base física, que usa uma rede de planos e canais que representam os cursos d'água na bacia; sendo assim, a bacia é representada por uma cascata de planos e canais. As equações diferenciais que descrevem o escoamento superficial, o transporte de sedimentos e a deposição de sedimentos nesses planos e canais são resolvidas pela técnica de diferenças finitas.

O modelo KINEROS2 é uma versão melhorada do modelo KINEROS, e traz como diferencial a redistribuição da umidade do solo durante a chuva e a capacidade de comportar dados de mais de um pluviógrafo (SMITH et al., 1993). 
Quadro 1 - Modelos perda de solo e de produção de sedimentos

\begin{tabular}{|c|c|c|c|c|c|}
\hline Modelo & Tipo & $\begin{array}{l}\text { Escala } \\
\text { espacial }\end{array}$ & $\begin{array}{c}\text { Escala } \\
\text { temporal }\end{array}$ & Outputs & Referência \\
\hline USLE & Empírico & Encosta & Anual & Erosão & $\begin{array}{l}\text { Wischmeier e } \\
\text { Smith, } 1978\end{array}$ \\
\hline MUSLE & Empírico & $\begin{array}{l}\text { Encosta/ } \\
\text { bacia }\end{array}$ & Evento & Produção de sedimento & Williams, 1975 \\
\hline RUSLE & Empírico & Encosta & Anual & Erosão & Renard et al.,1991 \\
\hline CREAMS & Físico & $\begin{array}{l}\text { Parcelas/ } \\
\text { campo }\end{array}$ & $\begin{array}{l}\text { Evento/ } \\
\text { contínua }\end{array}$ & Erosão, deposição & Knisel, 1985 \\
\hline WEPP & Físico & $\begin{array}{l}\text { Encosta/ } \\
\text { bacia }\end{array}$ & Contínua & $\begin{array}{l}\text { Escoamento superficial, } \\
\text { erosão, produção de } \\
\text { sedimento }\end{array}$ & $\begin{array}{c}\text { Flanagan e } \\
\text { Nearing, } 1995\end{array}$ \\
\hline KINEROS & Físico & $\begin{array}{l}\text { Encosta/ } \\
\text { pequenas } \\
\text { bacias }\end{array}$ & Evento & $\begin{array}{l}\text { Escoamento superficial, } \\
\text { taxa de pico, erosão, } \\
\text { produção de sedimento }\end{array}$ & $\begin{array}{c}\text { Woolhiser et al., } \\
1990\end{array}$ \\
\hline WESP & Físico & $\begin{array}{l}\text { Pequenas } \\
\text { bacias }\end{array}$ & Contínua & $\begin{array}{l}\text { Escoamento superficial, } \\
\text { taxa de pico, erosão, } \\
\text { produção de sedimento }\end{array}$ & Lopes, 1987 \\
\hline LISEM & Físico & $\begin{array}{l}\text { Pequenas } \\
\text { bacias }\end{array}$ & Evento & $\begin{array}{l}\text { Escoamento superficial, } \\
\text { produção de sedimento }\end{array}$ & $\begin{array}{c}\text { De Roo e Jetten, } \\
1999\end{array}$ \\
\hline AGNPS & Conceitual & $\begin{array}{l}\text { Pequenas } \\
\text { bacias }\end{array}$ & $\begin{array}{l}\text { Evento/ } \\
\text { contínua }\end{array}$ & $\begin{array}{l}\text { Escoamento superficial, } \\
\text { taxa de pico, erosão, } \\
\text { produção de sedimento }\end{array}$ & Young et al.,1989 \\
\hline SWAT & Conceitual & Bacia & Contínua & $\begin{array}{l}\text { Escoamento superficial, } \\
\text { taxa de pico, erosão, } \\
\text { produção de sedimento }\end{array}$ & Arnold et al.,1998 \\
\hline
\end{tabular}

Fonte: Adaptado de Merrit et al. 2003

De acordo com Santos (2009), o Modelo WESP (Watershed Erosion Simulation Program) utiliza a componente hidráulica do modelo KINEROS e as técnicas de modelagem desenvolvidas no WEPP. Neste modelo, a bacia também é discretizada através de um sistema de planos de escoamento que descarregam em canais de drenagem. É um modelo distribuído, que simula eventos de chuva, e foi elaborado para ser aplicado a pequenas bacias nas regiões semiáridas. O modelo considera erosão por impacto das gotas de chuva e pelo fluxo superficial. Estes processos são considerados não permanentes e variados e são descritos dinamicamente utilizando taxas de erosão e deposição simultaneamente, ao invés da abordagem convencional onde são utilizadas funções de transporte de sedimentos para fluxo permanente. 
Segundo Uzeika (2009), outro modelo desenvolvido com o propósito de investigar o efeito das práticas conservacionistas na escala de pequenas bacias é o LISEM (Limburg Soil Erosion Model). É um modelo espacialmente distribuído com a finalidade de simular a erosão, transporte e deposição durante e imediatamente após um único evento em uma bacia. O LISEM tem como principais componentes a representação de processos hidrológicos, erosão em sulcos e em entressulcos e a fase de canal (agradação e degradação). Além desses, o modelo dispõe de um algoritmo adicional capaz de simular processos de erosão em ravinas, bem como possui a capacidade de simular as alterações provocadas pelo manejo nas condições de superfície e subsuperfície do solo.

O AGNPS (Agricultural Non-point Source Pollution Model) foi desenvolvido para avaliar práticas relacionadas ao manejo da agricultura, sendo largamente utilizado para simulação em grandes bacias agrícolas. Segundo Bittencourt et al. (1997), para desenvolvimento de seus arquivos de entrada, o modelo é associado a Sistemas de Informação Geográfica (SIG), permitindo simular um único evento de chuva por vez. Os elementos estimados incluem erosão do solo, produção de sedimentos e carga de nutrientes, sendo que para este último são necessários dados relativos às praticas agrícolas realizadas no local. $\mathrm{O}$ escoamento é simulado usando o método da curva-número, enquanto a produção de sedimentos é obtida através da MUSLE (CHRISTOFOLETTI, 1999).

Outro modelo matemático bastante utilizado é o SWAT (Soil and Water Assessment Tool), o qual permite simular diferentes fenômenos ambientais em ambiente SIG e foi desenvolvido pelo Agricultural Research Service e pela Texas A\&M University. O SWAT permite a análise dos impactos das alterações no uso do solo sobre o escoamento superficial e subterrâneo, sobre a produção de sedimentos e qualidade da água, permitindo a simulação de diferentes processos físicos em uma bacia hidrográfica (SRINIVASAN e ARNOLD, 1994). Um detalhamento maior acerca deste modelo é apresentado nas próximas seções.

\subsection{O modelo SWAT: características e aplicações}

O SWAT é um modelo matemático que permite a realização de simulações na escala espacial de bacias hidrográficas, operando em passo de tempo contínuo e apresentando parâmetros distribuídos. Tais características possibilitam que um grande número de diferentes processos físicos possa ser simulado com o intuito de analisar os impactos das alterações no uso do solo sobre o escoamento superficial e subsuperficial, a produção de sedimentos e 
também a qualidade da água em bacias não instrumentadas (SRINIVASAN e ARNOLD, 1994).

Por ser um modelo distribuído contínuo, o SWAT é capaz de simular os processos sequencialmente dentro do sistema físico, num intervalo de tempo delimitado pelo usuário, fornecendo séries temporais como dado de saída do modelo (TIM, 1996). O modelo opera em passo de tempo diário, sendo capaz de simular longos períodos, podendo desta forma computar os efeitos cumulativos das variações de manejo no uso e ocupação do solo.

A integração do modelo com os Sistemas de Informação Geográfica permite a manipulação de dados topográficos, pedológicos e de cobertura do solo, resultando em uma melhor representação da variabilidade espacial das características de uma determinada bacia hidrográfica.

Além disso, valendo-se das operações de modelagem espacial disponíveis nos SIG, o SWAT realiza a divisão da bacia em subunidades através de uma abordagem de duas etapas. Primeiro, baseando-se na topografia da área, a bacia hidrográfica é dividida em sub-bacias. Em seguida, cada sub-bacia é dividida em Unidades de Resposta Hidrológica (Hydrologic Response Units - HRU), que representam uma combinação única de tipo de solo e tipo de cobertura (BOURAOUI et al., 2005).

Subdividir a bacia em áreas contendo combinações únicas possibilita ao modelo refletir diferenças na evapotranspiração e outras condições hidrológicas para diferentes usos e solos. O escoamento é calculado para cada HRU e propagado para obter o escoamento total para a sub-bacia. Isso pode aumentar a precisão das predições e fornecer uma melhor descrição física do balanço de água na bacia (ARNOLD et al., 1998).

De acordo com Minotti (2006), para execução da simulação são necessárias informações específicas sobre o clima, as propriedades do solo, a topografia, a vegetação e as práticas de manejo do solo que ocorrem na bacia hidrográfica. Os processos físicos associados ao movimento da água, movimento dos sedimentos, crescimento das culturas, ciclagem de nutrientes, entre outros, são diretamente modelados pelo simulador utilizando esses dados de entrada.

O SWAT vem sendo aplicado satisfatoriamente para diversas situações em várias regiões do mundo. Tanto nos Estados Unidos como na Europa, o uso do SWAT tem fomentado análises de capacidade de canais, avaliações da eficiência dos planos integrados para conservação de recursos hídricos, estudos da influência de cenários de uso do solo na poluição hídrica, estudos de impactos hidrológicos provocados pela mudança climática, dentre outros. (GASSMAN et al., 2007). 
A utilização do SWAT em bacias hidrográficas situadas em diferentes países comprova o potencial e aplicabilidade do simulador nas mais variadas condições. No Quadro 2 é apresentada uma breve compilação de alguns destes trabalhos, realizados tanto no Brasil como no exterior.

Quadro 2 - Compilação de alguns trabalhos utilizando o SWAT

\begin{tabular}{|c|c|c|c|}
\hline Referência & Local de aplicação & Extensão & Descrição da utilização do SWAT \\
\hline $\begin{array}{l}\text { Tripathi et } \\
\text { al.(2003) }\end{array}$ & $\begin{array}{l}\text { Bacia do Rio Nagwan } \\
\text { (Bihar-Índia) }\end{array}$ & $92 \mathrm{~km}^{2}$ & $\begin{array}{l}\text { Simulação de escoamento superficial, } \\
\text { produção de sedimentos e perdas de } \\
\text { nutrientes. Realizou a calibração e } \\
\text { validação dos resultados. }\end{array}$ \\
\hline $\begin{array}{l}\text { Govender e } \\
\text { Everson } \\
(2005)\end{array}$ & $\begin{array}{l}\text { Bacias experimentais em } \\
\text { Cathedral Peak (KwaZulu- } \\
\text { Natal - África do Sul) }\end{array}$ & $\begin{array}{c}0,67 \mathrm{~km}^{2} \mathrm{e} \\
1,94 \mathrm{~km}^{2}\end{array}$ & $\begin{array}{l}\text { Simulação de vazões liquidas diárias } \\
\text { em duas diferentes bacias. Realizou } \\
\text { calibração e validação dos resultados. }\end{array}$ \\
\hline $\begin{array}{l}\text { Parajuli et al. } \\
\quad \text { (2008) }\end{array}$ & $\begin{array}{c}\text { Bacia do Rio Wakarusa } \\
\text { (Kansas - Estados Unidos) }\end{array}$ & $950 \mathrm{~km}^{2}$ & $\begin{array}{c}\text { Simulação da produção de sedimentos } \\
\text { e de bactérias. Realizou a calibração e } \\
\text { validação dos resultados. }\end{array}$ \\
\hline $\begin{array}{l}\text { Machado e } \\
\text { Vettorazzi } \\
\text { (2003) }\end{array}$ & $\begin{array}{l}\text { Bacia do Ribeirão dos } \\
\text { Marins (Piracicaba - SP) }\end{array}$ & $59 \mathrm{~km}^{2}$ & $\begin{array}{l}\text { Simulação da produção de sedimentos } \\
\text { sob diferentes cenários. Realizou a } \\
\text { calibração dos resultados. }\end{array}$ \\
\hline $\begin{array}{l}\text { Baldissera } \\
\quad(2005)\end{array}$ & $\begin{array}{l}\text { Bacia do Rio Cuiabá } \\
\text { (Cuiabá-MT) }\end{array}$ & $29.000 \mathrm{~km}^{2}$ & $\begin{array}{l}\text { Simulação de vazões líquidas mensais } \\
\text { sob diferentes cenários. Realizou a } \\
\text { calibração e validação dos resultados. }\end{array}$ \\
\hline $\begin{array}{l}\text { Minoti } \\
(2006)\end{array}$ & $\begin{array}{l}\text { Bacias do Córr. do Beija- } \\
\text { Flor e do Ribeirão das } \\
\text { Gabirobas (São Carlos -SP) }\end{array}$ & $\begin{array}{l}79 \mathrm{~km}^{2} \mathrm{e} \\
51 \mathrm{~km}^{2}\end{array}$ & $\begin{array}{l}\text { Simulação da produção de sedimentos } \\
\text { e alguns parâmetros do balanço hídrico } \\
\text { sob diferentes cenários. }\end{array}$ \\
\hline $\begin{array}{l}\text { Baltokoski et } \\
\text { al. }(2010)\end{array}$ & $\begin{array}{l}\text { Bacias do Rio Conrado e do } \\
\text { Rio Pinheiro (Pato Branco e } \\
\text { Mariópolis - PR) }\end{array}$ & $\begin{array}{l}24 \mathrm{~km}^{2} \mathrm{e} \\
28 \mathrm{~km}^{2}\end{array}$ & $\begin{array}{l}\text { Simulação do escoamento superficial, } \\
\text { da produção de sedimentos e de fósforo } \\
\text { total sob diferentes cenários. Realizou a } \\
\text { calibração dos resultados. }\end{array}$ \\
\hline
\end{tabular}

Tripathi et al. (2003) utilizaram o SWAT na simulação de escoamento superficial, produção de sedimentos e perdas de nutrientes em uma bacia agrícola localizada em Nagwan, na Índia. Foram utilizadas para calibração séries de dados observados de um período de sete anos. Depois de validados, os autores utilizaram os resultados obtidos pelo simulador para a identificação e priorização de sub-bacias críticas, de modo a desenvolver planos de manejo do solo eficientes. 
Govender e Everson (2005) aplicaram o SWAT em duas pequenas bacias na África do Sul, uma delas coberta por vegetação rasteira (área de $0,67 \mathrm{~km}^{2}$ ) e outra ocupada com reflorestamento de pinheiros $\left(1,94 \mathrm{~km}^{2}\right)$, com o objetivo de simular a vazão e outros processos hidrológicos. Após a calibração do modelo, os autores observaram que apenas na primeira bacia foram obtidos resultados satisfatórios, enquanto para a segunda os valores de vazão foram superestimados. $\mathrm{O}$ autor verificou ainda que o desempenho do modelo foi melhor para anos secos do que para anos úmidos, havendo nestes últimos uma subestimativa dos picos de escoamento superficial.

Parajuli et al. (2008) aplicaram o SWAT na bacia do rio Wakarusa, no estado de Kansas, Estados Unidos, com o intuito de avaliar a eficiência de faixas de vegetação marginais na manutenção da qualidade da água, de modo a realizar uma caracterização quanto ao aporte de sedimentos e de coliformes fecais. Depois da calibração e validação do modelo para as condições de uso atuais, os autores simularam faixas vegetativas de $0,10,15$ e 20 metros, verificando através das simulações a redução da produção de sedimentos e dos teores de coliformes fecais conforme o aumento da faixa.

No Brasil, diversos centros de pesquisa têm utilizado o SWAT para as mais diversas aplicações. Garbossa et al. (2011) realizaram um levantamento para identificar as aplicações do modelo em bacias hidrográficas brasileiras de 1999 a 2010. Os autores compilaram informações referentes a setenta publicações, onde verificaram que $43 \%$ delas tratavam da simulação de sedimentos, $41 \%$ da simulação de vazões líquidas e $16 \%$ da simulação de nutrientes. Também foi verificada a existência de trabalhos em todas as grandes regiões do país, com a maioria das aplicações situadas na Região Sul, seguida pela Região Sudeste.

Machado e Vettorazzi (2003) utilizaram o SWAT para simular a produção de sedimentos na Bacia do Ribeirão dos Marins (Piracicaba - SP). Os resultados obtidos na simulação foram comparados aos dados observados em um posto hidrossedimentométrico, apresentando um bom ajuste. Segundo os autores, os processos hidrológicos associados ao uso e manejo da terra exercem claramente um papel dominante na simulação da produção e transporte de sedimentos.

Baldissera (2005) avaliou a aplicabilidade do modelo SWAT para a simulação de vazões líquidas mensais na Bacia do Rio Cuiabá, em Cuiabá-MT, sendo um dos primeiros trabalhos no Brasil a realizar a simulação para grandes bacias. As médias mensais simuladas da vazão líquida foram comparadas com dados observados em cinco postos fluviométricos através de diferentes testes estatísticos, os quais apresentaram-se compatíveis com os dados da maioria dos postos. 
Minoti (2006) utilizou o modelo em duas diferentes sub-bacias localizadas na região de São Carlos-SP com o objetivo de simular a produção de sedimentos e alguns parâmetros do balanço hídrico para as bacias sob diferentes cenários. Apesar de não ter realizado a calibração do modelo, o autor utilizou simultaneamente outros modelos de perda de solo, os quais geraram respostas complementares com os resultados gerados pelo SWAT. Ainda segundo o autor, o modelo apresentou-se bastante sensível às mudanças de cenários de uso do solo.

Baltokoski et al. (2010) fez uso do simulador para avaliar o escoamento superficial, a produção de sedimentos e o fluxo de massa de fósforo total nas microbacias do Rio Conrado e do Rio Pinheiro, localizadas nos municípios de Pato Branco e Mariópolis, no Estado do Paraná. Após a calibração dos resultados, os autores verificaram bons resultados para a vazão e produção de sedimentos, enquanto que para o fósforo os resultados foram razoáveis. Os autores consideram o modelo eficiente dada as condições brasileiras, onde é difícil utilizar modelos determinísticos, principalmente devido às limitações de equipamentos e de verbas.

\subsection{Estrutura do modelo SWAT}

De acordo com Chen e MacKay (2004), a utilização de submodelos é uma estratégia para tornar modelos hidrológicos capazes de representar a complexidade dos sistemas naturais. Nesse contexto, o SWAT integra submodelos para avaliar a erosão do solo, a produção de escoamento superficial e de sedimentos e o transporte no canal por meio da análise de vários componentes que sofrem influência da dinâmica característica de uma bacia hidrográfica.

Nesta seção serão brevemente apresentadas as principais rotinas utilizadas pelo simulador referentes à modelagem hidrológica e à produção de sedimentos, segundo informações extraídas do manual teórico do SWAT (NEITSCH et al., 2005)

\subsubsection{Balanço hídrico e modelagem hidrológica}

Os fenômenos simulados pelo SWAT têm como principal fator controlador a equação geral do balanço hídrico, apresentada na equação 2 .

$$
\mathrm{SW}_{\mathrm{t}}=\mathrm{SW}_{0}+\sum_{\mathrm{i}=1}^{\mathrm{t}}\left(\mathrm{R}_{\text {day }}-\mathrm{Q}_{\text {surf }}-\mathrm{E}_{\mathrm{a}}-\mathrm{W}_{\text {seep }}-\mathrm{Q}_{\mathrm{gw}}\right)
$$


Onde:

$\mathrm{SW}_{\mathrm{t}}=$ conteúdo final de água no solo $(\mathrm{mm})$;

$\mathrm{SW}_{0}=$ conteúdo inicial de água no solo no dia i $(\mathrm{mm})$;

$\mathrm{t}=$ tempo $($ dias $)$;

$\mathrm{R}_{\text {day }}=$ precipitação no dia $\mathrm{i}(\mathrm{mm})$;

$\mathrm{Q}_{\text {surf }}=$ escoamento superficial no dia i (mm);

$\mathrm{E}_{\mathrm{a}}=$ evapotranspiração no dia i (mm);

$\mathrm{W}_{\text {seep }}=$ quantidade de água que entra na zona vadosa percolada através do perfil (mm);

$\mathrm{Q}_{\mathrm{gw}}=$ quantidade de água que retorna ao curso d'água no dia i devido ao escoamento subsuperficial (fluxo de retorno) $(\mathrm{mm})$.

Segundo Neitsch et al. (2005), o sistema hidrológico simulado pelo SWAT compreende quatro principais componentes: os reservatórios superficiais, os reservatórios subsuperficiais, os reservatórios subterrâneos (aquíferos rasos ou livres) e os reservatórios subterrâneos (aquífero profundo).

A contribuição desses reservatórios para o escoamento no canal provém do escoamento lateral a partir do perfil de solo e do escoamento de retorno do aquífero raso. $\mathrm{O}$ volume que percola do reservatório subsuperficial através do perfil de solo representa a recarga do aquífero raso. Já a água que percola para o aquífero profundo não retorna para o sistema (UZEIKA, 2009).

\section{Escoamento superficial}

O escoamento superficial ou deflúvio ocorre a partir do instante que o volume de água que alcança o solo excede a sua taxa de infiltração ou a sua capacidade de armazenamento. Para sua quantificação, o SWAT possibilita a utilização opcional de dois métodos: o Método da Curva Número (Curve Number), do Soil Conservation Service (SCS), a ser abordado nesta seção, e o Método de Infiltração de Green e Ampt (NEITSCH et al. , 2005).

O Método da Curva Número (Estados Unidos, 1972) tem como principal variável o número da curva de escoamento superficial $(\mathrm{CN})$, que é estimado com base nas informações de cobertura do solo, do tipo de solo e das condições de umidade antecedente. Geralmente tal fator é obtido através de tabelas que relacionam o parâmetro $\mathrm{CN}$ com diversos tipos de 
cobertura do solo e com agrupamentos de solos classificados de acordo com suas características de infiltração, denominados grupos hidrológicos.

Um grupo hidrológico é definido como um conjunto de solos que apresentam potenciais similares de produção de escoamento superficial sob mesmas condições de chuva e cobertura. O Serviço de Conservação dos Recursos Naturais dos Estados Unidos (NRCS) classifica os solos em quatro grupos hidrológicos, denominados grupos A, B, C e D. Nesta classificação, tem-se em um extremo os solos do grupo A, que possuem elevada taxa de infiltração e produzem pouco escoamento superficial, e, no outro extremo, os solos do grupo $\mathrm{D}$, os quais geram a maior proporção de escoamento superficial, motivo de sua baixa capacidade de infiltração (NEITSCH et al. , 2005; MINOTI, 2006).

O escoamento superficial é calculado pelo Método da Curva Número através da equação 3:

$$
\mathrm{Q}_{\text {surf }}=\frac{\left(\mathrm{R}_{\mathrm{day}}-0,2 \cdot \mathrm{S}\right)^{2}}{\left(\mathrm{R}_{\mathrm{day}}+0,8 \cdot \mathrm{S}\right)}
$$

Onde:

$\mathrm{Q}_{\text {surf }}=$ quantidade de escoamento superficial acumulado ou excesso de chuva (mm);

$\mathrm{R}_{\text {day }}=$ quantidade de chuva em um dia $(\mathrm{mm})$;

$\mathrm{S}=$ parâmetro de retenção.

O parâmetro de retenção S varia espacialmente em função dos diversos usos da terra, do manejo e da declividade do terreno, e varia também temporalmente em função das variações da quantidade de água no solo, refletindo as condições de umidade. Este parâmetro está relacionado com o número da curva pela seguinte equação:

$$
\mathrm{S}=25,4\left(\frac{100}{\mathrm{CN}}-10\right)
$$

Onde:

$\mathrm{CN}$ = número da curva para um determinado dia.

No modelo SWAT, o fator CN é determinado diariamente, variando numericamente de 1 a 100, sendo o limite inferior representativo de um solo totalmente permeável e o limite 
superior de um solo que converterá toda a precipitação em escoamento (totalmente impermeável) (NEITSCH et al. , 2005).

$\mathrm{Na}$ simulação da propagação do deflúvio pela bacia, o modelo processa ainda um armazenamento temporário do escoamento superficial, visando simular seu retardamento para alcançar o canal principal.

\section{Evapotranspiração}

O modelo SWAT permite o cálculo da evapotranspiração potencial através de três métodos: Pennman-Monteith (Monteith, 1965), Priestley-Taylor (Priestley e Taylor, 1972) e Hargreaves (Hargreaves et al.,1985). Para a correta estimativa desta variável, o modelo requer dados médios climáticos mensais referentes ao período simulado. Ainda é possível entrar diretamente com os dados de evapotranspiração observados para o período simulado.

Uma vez que a evapotranspiração potencial é determinada, busca-se a evapotranspiração real através da demanda evaporativa da precipitação interceptada pela cobertura vegetal, da transpiração dos vegetais e da evaporação do solo (NETO, 2011).

Segundo Minoti (2006), o modelo considera que, se a evapotranspiração potencial for inferior à quantidade de água livre nas plantas:

$$
\mathrm{E}_{\mathrm{a}}=\mathrm{E}_{0} \rightarrow \mathrm{R}_{\mathrm{INT}(\mathrm{f})}=\mathrm{R}_{\mathrm{INT}(\mathrm{i})}-\mathrm{E}_{\mathrm{a}}
$$

Se a evapotranspiração potencial for superior, tem-se:

$$
\mathrm{E}_{\text {can }}=\mathrm{R}_{\mathrm{INT}(\mathrm{i})} \rightarrow \mathrm{R}_{\mathrm{INT}(\mathrm{f})}=0
$$

Onde:

$\mathrm{E}_{\mathrm{a}}=$ evapotranspiração real diária $(\mathrm{mm})$;

$\mathrm{E}_{\mathrm{can}}=\mathrm{a}$ quantidade de evaporação diária da água livre nas plantas (mm);

$\mathrm{E}_{0}=$ evapotranspiração potencial diária $(\mathrm{mm})$;

$\mathrm{R}_{\mathrm{INT}(\mathrm{i})}=$ a quantidade inicial diária da água livre nas plantas $(\mathrm{mm})$;

$\mathrm{R}_{\mathrm{INT}(\mathrm{f})}=$ a quantidade final diária da água livre nas plantas em um dia (mm). 


\section{Percolação}

Segundo NEITSCH et al. (2005), a componente percolação do SWAT usa uma técnica de propagação do armazenamento combinada ao modelo do fluxo em fendas no solo para simular o escoamento através de cada camada do perfil.

O volume de água disponível para percolar deve obedecer a seguinte condição:

$$
\begin{array}{lll}
\mathrm{SW}_{\mathrm{ly}, \text { excess }}=\mathrm{SW}_{\mathrm{ly}}-\mathrm{FC}_{\mathrm{ly}} & \text { se } & \mathrm{SW}_{\mathrm{ly}}>\mathrm{FC}_{\mathrm{ly}} \\
\mathrm{SW}_{\mathrm{ly} \text {,excess }}=0 & \text { se } & \mathrm{SW}_{\mathrm{ly}}<\mathrm{FC}_{\mathrm{ly}}
\end{array}
$$

Onde:

$\mathrm{SW}_{\text {ly,excess }}=$ quantidade de água disponível para percolar em uma camada de solo, em um determinado dia $(\mathrm{mm})$;

$\mathrm{SW}_{\mathrm{ly}}=$ é a quantidade de água em uma camada de solo, em um determinado dia (mm);

$\mathrm{FC}_{\mathrm{ly}}=$ é a quantidade de água de uma camada de solo na capacidade de campo (mm).

A quantidade de água que efetivamente se moverá para a camada de solo inferior é calculada pela equação:

$$
\mathrm{W}_{\text {perc,ly }}=\mathrm{SW}_{\text {ly,excess }} \cdot\left(1-\exp \left[\frac{-\Delta \mathrm{t}}{\mathrm{TT}_{\text {perc }}}\right]\right)
$$

\section{Em que:}

$\mathrm{W}_{\text {perc,ly }}=$ quantidade de água que efetivamente percola no dia (mm);

$\Delta \mathrm{t}=$ duração do intervalo de tempo (h);

$\mathrm{TT}_{\text {perc }}=$ tempo de percolação entre as camadas $(\mathrm{h})$.

O tempo de percolação é único para cada uma das camadas, sendo dado por:

$$
\mathrm{TT}_{\mathrm{perc}}=\frac{\mathrm{SAT}_{\mathrm{ly}}-\mathrm{FC}_{\mathrm{ly}}}{\mathrm{K}_{\mathrm{sat}}}
$$

$\mathrm{SAT}_{\text {ly }}=$ quantidade de água no solo completamente saturado (mm); 
$\mathrm{K}_{\mathrm{sat}}=$ condutividade hidráulica saturada da camada $\left(\mathrm{mm} \cdot \mathrm{h}^{-1}\right)$.

A água que percola abaixo da última camada do solo entra na zona vadosa, a qual corresponde à zona insaturada entre o término do perfil de solo e o topo do aquífero subterrâneo.

\section{Fluxo lateral}

No cálculo do fluxo lateral, o SWAT utiliza um modelo de armazenamento cinemático baseado na equação de continuidade de massa, no qual considera o balanço hídrico com todo o segmento da encosta utilizado como volume de controle, em um fluxo bi-dimensional (NEITSCH et al. , 2005). Desse modo, o escoamento sub-superficial lateral é estimado pela seguinte equação:

$$
\mathrm{Q}_{\mathrm{lat}}=0,024 \cdot\left(\frac{2 \cdot \mathrm{SW}_{\mathrm{ly}, \mathrm{excess}} \cdot \mathrm{K}_{\mathrm{sat}} \cdot \mathrm{slp}}{\varphi_{\mathrm{d}} \cdot \mathrm{L}_{\mathrm{hill}}}\right)
$$

Onde:

$\mathrm{Q}_{\text {lat }}=$ escoamento lateral $\left(\mathrm{mm} \cdot \mathrm{dia}^{-1}\right)$;

$\mathrm{SW}_{\mathrm{ly} \text {,excess }}=$ volume de água drenável armazenada na zona saturada da encosta por unidade de área $(\mathrm{mm})$;

$\mathrm{K}_{\text {sat }}=$ condutividade hidráulica do solo saturada $\left(\mathrm{mm} \cdot \mathrm{hr}^{-1}\right)$;

Slp = declividade da encosta $(\mathrm{m} / \mathrm{m})$;

$\Phi_{\mathrm{d}}=$ porosidade drenável do solo $(\mathrm{mm} / \mathrm{mm}) ;$

$\mathrm{L}_{\text {hill }}=$ comprimento da encosta $(\mathrm{m})$.

Segundo Minoti (2006), o fluxo lateral poderá ser significante em áreas em que os solos apresentem elevada condutividade hidráulica nas camadas superficiais e camadas impermeáveis ou semipermeáveis em profundidades rasas. Em tais sistemas, a precipitação irá percolar verticalmente até atingir a camada impermeável. A água poderá se acumular acima dessa camada formando uma zona saturada de água que será a fonte para o fluxo lateral subsuperficial. 


\section{Vazão de pico}

Segundo Neitsch et al. (2005), a vazão de pico é a vazão máxima que ocorre no canal devido a um dado evento de chuva. O SWAT calcula a vazão de pico através do Método Racional Modificado, fundamentado na suposição de que, se uma chuva de intensidade $i$ inicia instantaneamente e continua indefinidamente, a vazão de pico do escoamento vai aumentar até o tempo de concentração, quando toda a sub-bacia estará contribuindo para o fluxo na saída. A equação do método racional é dada por:

$$
\mathrm{q}_{\text {peak }}=\frac{\alpha_{\mathrm{tc}} \cdot \mathrm{Q}_{\text {surf }} \cdot \mathrm{A}}{3,6 \cdot \mathrm{t}_{\text {conc }}}
$$

Onde:

$\mathrm{q}_{\text {peak }}=$ vazão de pico $\left(\mathrm{m}^{3} \cdot \mathrm{s}^{-1}\right)$;

$\alpha_{\mathrm{tc}}=$ fração da precipitação diária que ocorre durante o tempo de concentração;

$\mathrm{Q}_{\text {surf }}=$ volume de escoamento superficial $\left(\mathrm{mm} \cdot \mathrm{ha}^{-1}\right)$;

$\mathrm{A}=$ área da bacia $\left(\mathrm{km}^{2}\right)$;

$\mathrm{t}_{\text {conc }}=$ tempo de concentração da bacia $(\mathrm{h})$.

O tempo de concentração da bacia é obtido pela soma do tempo do fluxo superficial (tempo necessário para que a água precipitada no ponto mais distante da sub-bacia alcance o canal) e do tempo do fluxo no canal (tempo necessário para que a água do canal alcance o exutório).

\subsubsection{Produção e transporte de sedimentos}

O modelo SWAT estima o aporte de sedimentos através da Equação Universal de Perda de Solo Modificada - MUSLE (Williams, 1975), a qual se baseia na Equação Universal de Perda de Solo - EUPS (Wischmeier e Smith, 1978). A MUSLE apresenta o seguinte equacionamento:

$$
\operatorname{sed}=11,8 \cdot\left(\mathrm{Q}_{\text {surf }} \cdot \mathrm{q}_{\text {peak }} \cdot \operatorname{area}_{\text {hru }}\right)^{0,56} \cdot \mathrm{K}_{\mathrm{USLE}} \cdot \mathrm{C}_{\mathrm{USLE}} \cdot \mathrm{P}_{\mathrm{USLE}} \cdot \mathrm{LS}_{\mathrm{USLE}} \cdot \mathrm{CFRG}
$$


Onde:

sed = produção de sedimentos diária (ton);

$\mathrm{Q}_{\text {surf }}=$ lâmina de escoamento superficial $\left(\mathrm{mm} \cdot \mathrm{ha}^{-1}\right)$;

$\mathrm{q}_{\text {peak }}=$ vazão de pico $\left(\mathrm{m}^{3} \cdot \mathrm{s}^{-1}\right)$;

area $_{\text {hru }}=$ área da HRU (ha);

$\mathrm{K}_{\mathrm{USLE}}=$ fator erodibilidade $\left(\mathrm{t} \cdot \mathrm{h} \cdot \mathrm{MJ}^{-1} \cdot \mathrm{mm}^{-1}\right)$;

$\mathrm{C}_{\text {USLE }}=$ fator cobertura e manejo;

$\mathrm{P}_{\text {USLE }}=$ fator práticas conservacionistas;

$\mathrm{LS}_{\mathrm{USLE}}=$ fator topográfico;

$\mathrm{CFRG}=$ fator de fragmentação esparsa.

Os fatores $\mathrm{Q}_{\text {surf }}$ e $\mathrm{q}_{\text {peak }}$ da equação já tiveram suas formulações apresentadas nas seções anteriores. Os fatores K, C, P e LS da MUSLE são os mesmos da USLE, os quais também já foram descritos na seção 3.4. O fator CFRG considera o afloramento de rochas na área, através da seguinte equação:

$$
\mathrm{CFRG}=\exp (-0,053 \cdot \text { rock })
$$

$\mathrm{Na}$ qual o termo "rock" representa a porcentagem de rochas na primeira camada do solo, ou seja, a fração da área de afloramento rochoso.

No SWAT, o transporte de sedimentos se dá através da atuação de dois componentes: o primeiro deles considera o sedimento proveniente das vertentes da bacia, enquanto o segundo considera o transporte de sedimentos dentro do canal. Em relação ao sedimento produzido nas vertentes, o simulador encaminha as partículas erodidas conforme a sua distribuição de tamanho, simulando o seu transporte até os rios e reservatórios. No canal, são simulados os processos de degradação e deposição de sedimentos, os quais dependem de fatores como a velocidade do fluxo, a exposição das margens e do fundo do canal à força erosiva do rio e da composição dos bancos de material e do sedimento do leito.

\section{Propagação de sedimentos até o canal}

Em grandes bacias com tempo de concentração maior que um dia, somente uma parte do escoamento superficial alcança o canal principal no mesmo dia, assim o SWAT incorpora uma característica de armazenamento de escoamento superficial para retardar a chegada de 
uma porção desse escoamento ao canal principal juntamente com os sedimentos dessa porção (NEITSCH et al., 2005; UZEIKA, 2009).

Após calculada a carga de sedimento no escoamento superficial, a quantidade de sedimento que é liberada para o canal principal é dada pela equação:

$$
\operatorname{sed}=\left(\operatorname{sed}^{\prime}+\operatorname{sed}_{\text {stor, },-1}\right) \cdot\left(1-\exp \left[\frac{- \text { surlag }}{t_{\text {conc }}}\right]\right)
$$

Onde:

sed = quantidade de sedimento entregue no canal principal durante um dia (ton);

sed' = quantidade de sedimento gerada na HRU durante um dia (ton);

$\operatorname{sed}_{\text {stor, },-1}=$ sedimento retardado no dia anterior (ton);

surlag $=$ coeficiente de retardo do escoamento superficial (adimensional);

$\mathrm{t}_{\text {conc }}=$ tempo de concentração da HRU (h).

A quantidade de sedimentos que chega ao canal corresponde à produção total de sedimentos calculada pela MUSLE subtraídas as parcelas retidas pelo processo de retardamento, ou seja, os sedimentos depositados em faixas de vegetação, lagoas e em enxarcados. O simulador considera que as particulas mais grosseiras, como areia e agregados maiores, são os primeiros a serem retidos, sendo seguidos pelas particulas mais finas, como a argila, sendo por meio deste processo calculada a distribuição das partículas provenientes das vertentes que atingem o curso d'água (NEITSCH et al., 2005).

Além disso, o SWAT ainda permite que os materiais presentes nos escoamentos lateral e subterrâneo sejam computados no cálculo do aporte de sedimentos do canal principal.

\section{Propagação dos sedimentos no canal}

Segundo Setegn et al. (2009) apud Santos (2010), as rotinas de modelagem sedimentológica que simulam o transporte de sedimento através da rede de canais hídricos consistem em dois componentes, operando simultaneamente: deposição e degradação. Tais processos são estimados pelo modelo utilizando uma adaptação do método de Potência do Fluxo, proposto por Bagnold (1977). De início, a quantidade máxima que pode ser transportada pelo fluxo em determinado trecho é dada por: 
conc $_{\text {sed,ch,mx }}=\mathrm{c}_{\mathrm{sp}} \cdot \mathrm{v}_{\mathrm{ch}, \mathrm{pk}}$ spexp

Onde:

conc $_{\text {sed,ch,mx }}=$ concentração máxima de sedimentos que pode ser transportada pela água (ton. $\mathrm{m}^{-3}$ );

$\mathrm{v}_{\mathrm{ch}, \mathrm{pk}}=$ velocidade de pico $\left(\mathrm{m} \cdot \mathrm{s}^{-1}\right)$

csp e spexp $=$ coeficientes de ajuste.

Se a concentração máxima de sedimentos calculada pela equação 16 for menor que a concentração de sedimentos no início do processo, conc $_{\text {sed,ch,i }}>$ conc $_{\text {sed,ch,mx }}$, a agradação é o processo dominante sendo calculada por:

$$
\operatorname{sed}_{\mathrm{dep}}=\left(\text { conc }_{\mathrm{sed}, \mathrm{ch}, \mathrm{i}}-\text { conc }_{\mathrm{sed}, \mathrm{ch}, \mathrm{mx}}\right) \cdot \mathrm{V}_{\mathrm{ch}}
$$

Onde:

$\operatorname{sed}_{\text {dep }}=$ quantidade de sedimentos depositados no segmento do canal (ton);

conc $_{\text {sed,ch,i }}=$ concentração de sedimentos no início do processo (ton. $\mathrm{m}^{-3}$ );

$\mathrm{V}_{\mathrm{ch}}=$ volume de água que passa no segmento $\left(\mathrm{m}^{3}\right)$.

Se a concentração máxima de sedimento calculada pela equação 16 for maior que a concentração de sedimento no início do processo, $\operatorname{conc}_{\mathrm{sed,ch,i}}<\mathrm{conc}_{\mathrm{sed,ch,mx}}$, a degradação é o processo dominante, sendo calculada por:

$$
\operatorname{sed}_{\mathrm{deg}}=\left(\text { conc }_{\text {sed,ch,mx }}-\text { conc }_{\text {sed,ch,i }}\right) \cdot \mathrm{V}_{\mathrm{ch}} \cdot \mathrm{K}_{\mathrm{CH}} \cdot \mathrm{C}_{\mathrm{CH}}
$$

Onde:

$\operatorname{sed}_{\mathrm{deg}}=$ quantidade de sedimentos degradada (ton);

conc $_{\text {sed,ch,i }}=$ concentração de sedimentos no início do processo (ton. $\mathrm{m}^{-3}$ );

$\mathrm{V}_{\mathrm{ch}}=$ volume de água que passa no segmento $\left(\mathrm{m}^{3}\right)$;

$\mathrm{K}_{\mathrm{CH}}=$ fator de erodibilidade do canal $\left(\mathrm{cm} \cdot \mathrm{h}^{-1} \cdot \mathrm{Pa}^{-1}\right)$;

$\mathrm{C}_{\mathrm{CH}}=$ fator de cobertura do canal (adimensional). 
Uma vez que são calculadas as quantidades de sedimentos que deposita e erode, temse a estimativa final das partículas existentes no trecho, dada por:

$$
\operatorname{sed}_{\mathrm{ch}}=\operatorname{sed}_{\mathrm{ch,i}}-\operatorname{sed}_{\mathrm{dep}}+\operatorname{sed}_{\mathrm{deg}}
$$

Onde:

$\operatorname{sed}_{\mathrm{ch}}=$ quantidade de sedimentos suspensos no trecho, considerando o início do período de tempo (ton);

$\operatorname{sed}_{\mathrm{ch}, \mathrm{i}}=$ quantidade de sedimentos suspensos no trecho ao início do período de tempo (ton);

$\operatorname{sed}_{\text {dep }}=$ quantidade de sedimentos depositados no segmento de rio (ton);

$\operatorname{sed}_{\text {deg }}=$ quantidade de sedimentos degradada no segmento de rio (ton).

Por fim, a quantidade de sedimento que sai do trecho do canal é estimada através da seguinte equação:

$$
\operatorname{sed}_{\text {out }}=\operatorname{sed}_{\text {ch }} \cdot\left(\frac{V_{\text {out }}}{V_{\text {ch }}}\right)
$$

Onde:

$\operatorname{sed}_{\text {out }}=$ quantidade de sedimentos transportada para fora do segmento (ton);

$\operatorname{sed}_{\mathrm{ch}}=$ quantidade de sedimentos em suspensão no canal (ton);

$\mathrm{V}_{\text {out }}=$ volume de água que sai do segmento no intervalo de tempo considerado $\left(\mathrm{m}^{3}\right)$;

$\mathrm{V}_{\mathrm{ch}}=$ volume de água que passa no segmento $\left(\mathrm{m}^{3}\right)$.

Segundo Uzeika (2009), juntamente com a propagação de sedimentos, o SWAT simula também a propagação de água no canal, sendo que esse processo pode-se basear em duas rotinas de cálculo que são variações do Modelo de Onda Cinemática (Chow et al., 1988): Método da Média Variável (Williams, 1969) e Método de Muskingum (Overton, 1966). Esses métodos são apresentados detalhadamente por Neitsch et al. (2005). 


\section{4 ÁREA DE ESTUDO}

A bacia hidrográfica do Rio Itaqueri localiza-se na porção central do Estado de São Paulo, e está inserida na Unidade de Gerenciamento de Recursos Hídricos 13 - Tietê/Jacaré, mais precisamente no trecho correspondente ao alto curso do Rio Jacaré-Guaçu (Figura 2). Seu território abrange parte dos municípios de Itirapina e Brotas, compreendendo uma área de aproximadamente $220 \mathrm{~km}^{2}$ de extensão.

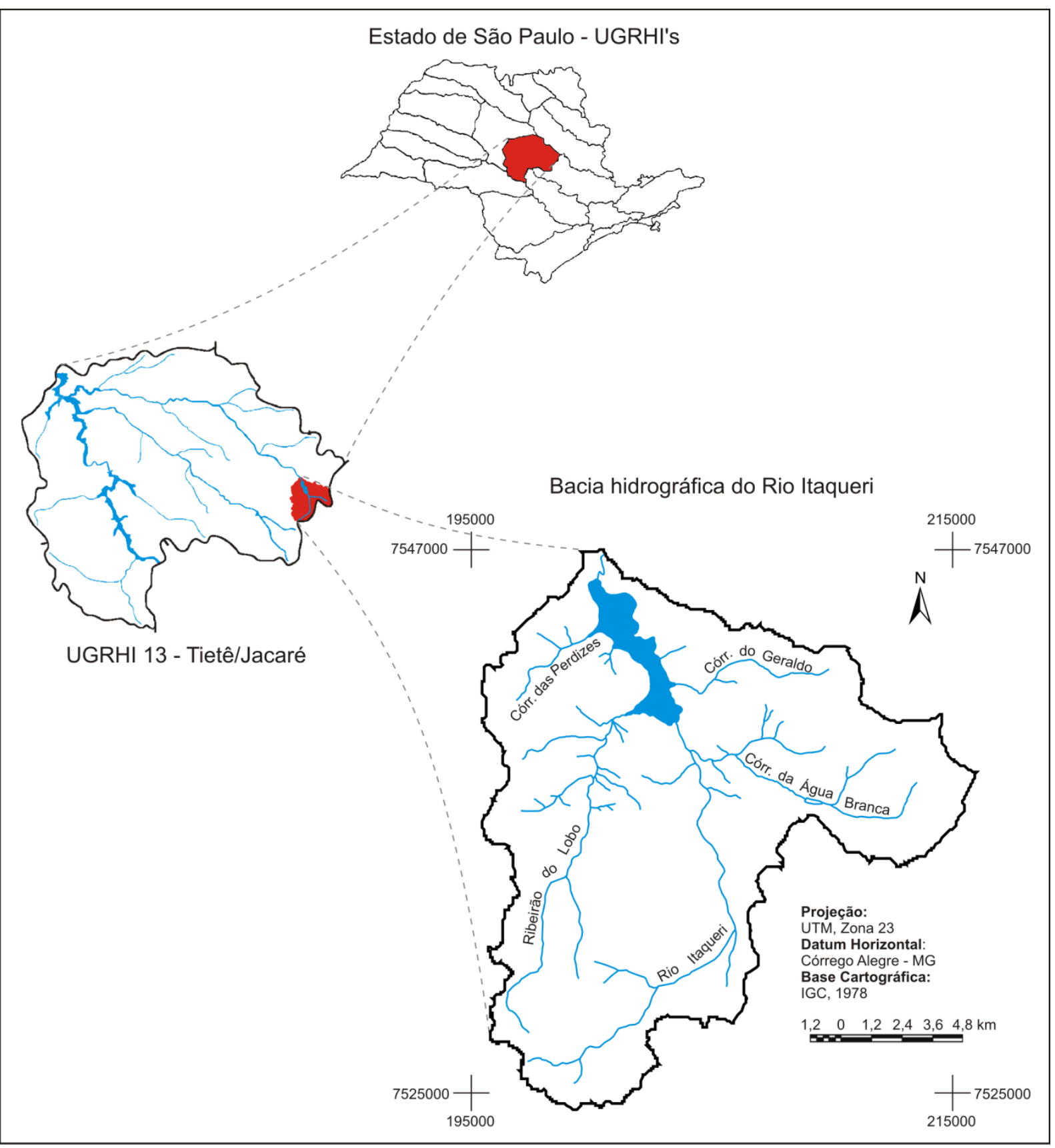

Figura 2 - Localização da área de estudo 
A rede hidrográfica da bacia apresenta como canais principais o Rio Itaqueri e o Ribeirão do Lobo, os quais abastecem em sua confluência o reservatório de armazenamento do Lobo ou do Broa. Além disso, deságuam no reservatório o Córrego do Geraldo, a leste, e o Córrego das Perdizes, a oeste, além de outros afluentes de menor importância.

Todos os cursos d'água integrantes da bacia estão enquadrados, segundo a Resolução CONAMA nº 20/86, na Classe 2, ou seja, são águas destinadas ao abastecimento doméstico após tratamento convencional, à proteção das comunidades aquáticas, recreação e irrigação de hortaliças e plantas frutíferas.

O Reservatório Carlos Botelho, também conhecido como Reservatório do Lobo ou do Broa, com seus $6,8 \mathrm{~km}^{2}$ de espelho d'água, teve como principal objetivo em sua concepção a produção de energia elétrica em pequena escala. Este foi construído em 1936 pela Central Elétrica de Rio Claro S. A. (SACERC), que hoje faz parte da Elektro/Centrais Elétricas de São Paulo (CESP). Com o passar dos anos, outros complexos hidrelétricos foram construídos suprindo as necessidades energéticas das diversas regiões do país. Assim, pequenos reservatórios, como a Represa do Lobo, deixaram de ter a função principal de gerar energia, passando a ser usados em atividades voltadas ao lazer (TUNDISI, 1988; ARGENTON, 2004).

Durante a década de 1970, a recreação surgiu como uma grande alternativa ao desenvolvimento da região, iniciando-se os primeiros loteamentos de casas de veraneio no entorno da represa. A reorganização da ocupação de seu entorno, agora voltada ao turismo, se deu de forma lenta e desordenada, com pouca interferência do poder público, esboçando-se ao longo deste processo uma forte segregação sócioespacial (QUEIROZ, 2000).

Neste processo de urbanização, a área foi submetida a uma intensa especulação imobiliária que promoveu o retalhamento dos terrenos e a concentração de pessoas, bem como estimulou a criação de condomínios e demais construções, avançando sobre os ecossistemas naturais como o cerrado, as áreas de mananciais e as áreas de preservação permanente (AZEVEDO, 2010).

Além dos impactos causados pela atividade turística, a região do Broa está passando por uma rápida conversão das atividades de uso e ocupação do solo, o que tem acelerado os desequilíbrios ecológicos e a perda da biodiversidade devido à simplificação da paisagem. Usos anteriores da terra, caracterizados por pastagens, pequenas lavouras, pequenos núcleos de silviculturas e áreas de capoeira, estão sendo convertidos unicamente em monoculturas de cana-de-açúcar ou plantações de eucalipto, sem um planejamento adequado da sua expansão (AZEVEDO, 2010). 
Apesar das pressões exercidas pelos fatores citados, há um grande interesse na conservação da qualidade ambiental da área de estudo. De acordo com o Decreto Estadual no 20.960, de 8 de junho de 1983, a bacia do Rio Itaqueri está inserida na Área de Proteção Ambiental (APA) do Corumbataí, Botucatu e Tejupá, a qual conta com uma área total de 649.828 ha e possui territórios em mais de trinta municípios.

Segundo Queiroz (2000), este Decreto Estadual foi instituído pelo fato da região possuir uma diversidade de ambientes naturais razoavelmente conservados, ricos patrimônios arqueológico e histórico, recursos hidrológicos de qualidade e elementos da paisagem que se destacam entre os atributos ecológicos. No entanto, diversos usos não compatíveis com a sustentabilidade ambiental ocorrem na região, destacando-se os usos destinados às atividades turísticas, a pesca predatória, a construção de condomínios e o desmatamento em áreas de preservação permanente, a expansão do cultivo de cana-de-açúcar, a extração de areia à montante do reservatório, entre outros impactos verificados em toda a extensão próxima aos rios Itaqueri e Lobo.

Além disso, estão compreendidas no interior da bacia duas unidades de conservação: as Estações Ecológica e Experimental de Itirapina, com áreas de 2.300 ha e 3.212 ha, respectivamente. Tais estações possuem amostras significativas da vegetação de cerrado e campo cerrado, ecossistemas que foram quase que totalmente dizimados no Estado de São Paulo em decorrência da expansão da atividade agrícola.

A Estação Ecológica, enquanto unidade de proteção integral, tem como objetivos a preservação da natureza e a realização de pesquisas científicas; já a Estação Experimental está destinada, sobretudo, ao desenvolvimento de atividades silviculturais e visitação pública (DELGADO et al., 2004). 


\section{PROCEDIMENTOS METODOLÓGICOS}

Neste capítulo são apresentados os procedimentos utilizados para a construção da base cartográfica da área de estudo, bem como as etapas de levantamento e compilação dos dados de entrada requeridos pelo modelo SWAT. São também descritos os procedimentos realizados em campo e em laboratório envolvendo a coleta e análise das amostras de água e sedimento do leito.

\subsection{Preparação da base cartográfica e criação do banco de dados espacial}

A etapa inicial em trabalhos envolvendo modelagem por meio de Sistemas de Informação Geográfica é a preparação da base cartográfica a ser utilizada como referência. Para a criação do banco de dados referente à área de estudo, foi utilizado como base de referência o mapeamento planialtimétrico realizado pelo Instituto Geográfico e Cartográfico do Estado de São Paulo - IGC (1978), cuja escala é de 1:10.000, sistema de projeção UTM. Na Figura 3 é apresentada a articulação espacial das cartas topográficas utilizadas.

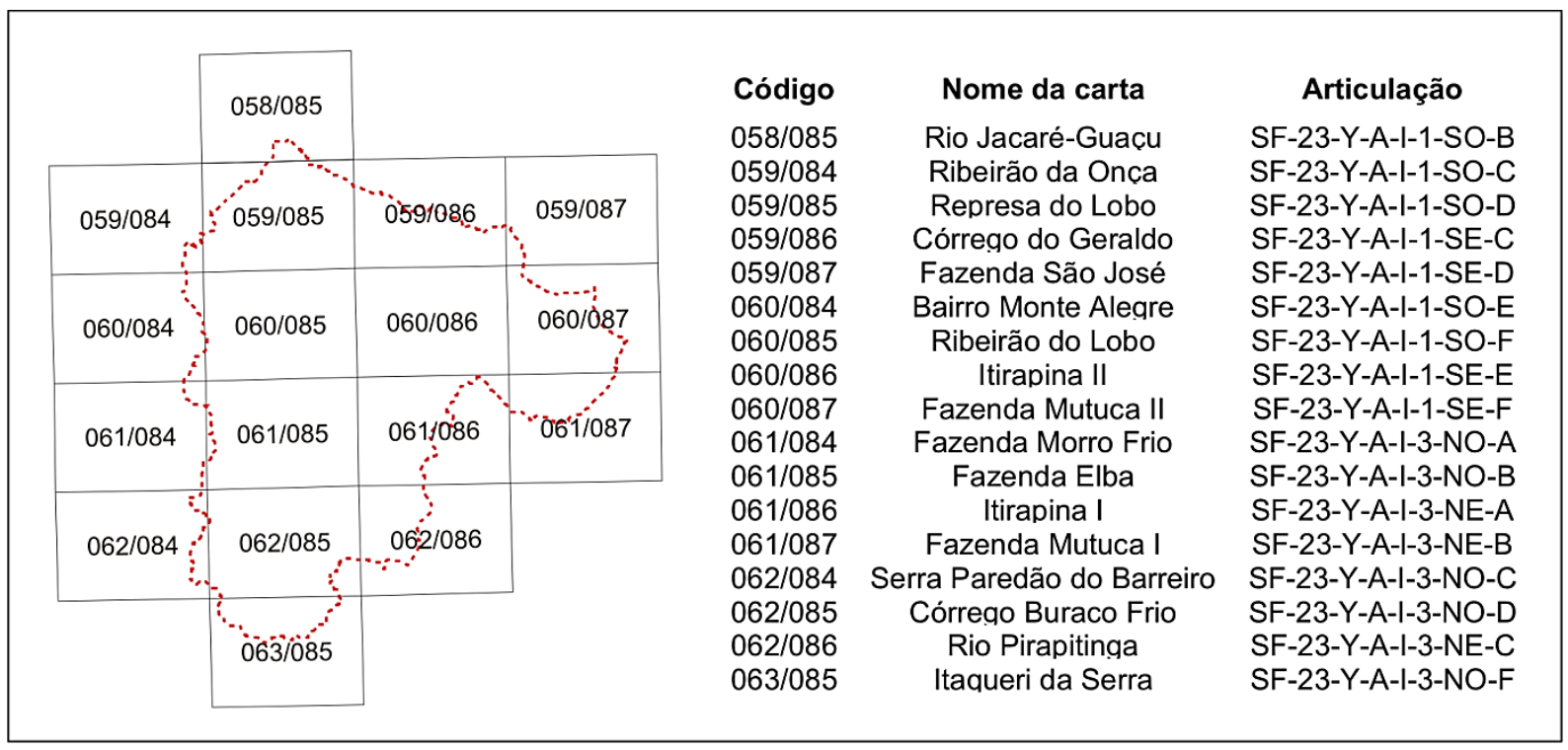

Figura 3 - Articulação das folhas utilizadas

Nesta primeira etapa do trabalho, foi utilizado o software SPRING 5.1, desenvolvido pelo Instituto Nacional de Pesquisas Espaciais - INPE (2009), como plataforma para criação do banco de dados. Após a digitalização das cartas topográficas por meio de scanner, estas foram georreferenciadas e vetorizadas manualmente. Os elementos vetorizados foram as 
curvas de nível, cuja equidistância original nas cartas é de 5 metros, os pontos cotados relativos a topos e depressões, a hidrografia e os limites dos terrenos sujeitos à inundação.

Além das cartas do levantamento topográfico, foram digitalizados e vetorizados os mapas temáticos relativos à geologia, geomorfologia e pedologia visando uma melhor caracterização do meio físico da área de estudo.

As informações referentes à geologia da área da bacia foram extraídas a partir do Mapa Geológico do Estado de São Paulo, elaborado pelo Serviço Geológico do Brasil CPRM na escala 1:750.000 (CPRM, 2006). Em relação à geomorfologia, foi utilizado o Mapa Geomorfológico do Estado de São Paulo, produzido pelo Instituto de Pesquisas Tecnológicas - IPT, na escala 1:1.000.000 (IPT, 1981).

Para a caracterização da pedologia, foi utilizada a carta de solos da Quadrícula de São Carlos, folha SF 23-Y-A-I, referente ao levantamento pedológico semi-detalhado do Estado de São Paulo, publicado pela EMBRAPA em parceria com o Instituto Agronômico de Campinas - IAC, na escala de 1:100.000 (EMBRAPA, 1981).

Como tal mapeamento pedológico segue a nomenclatura antiga de classificação de solos, optou-se por realizar a conversão das unidades pedológicas para a nomenclatura utilizada no atual Sistema Brasileiro de Classificação de Solos, considerando até o terceiro nível categórico de classificação. Nos compartimentos pedológicos onde havia ocorrência de associações de dois ou mais tipos de solo, considerou-se apenas a unidade predominante, conforme apontado na legenda do mapa original. A conversão da legenda de solos até o terceiro nível categórico foi realizada em função da descrição das características químicas das unidades encontradas na bacia, apresentadas por Oliveira e Prado (1984), sendo utilizados para a reclassificação os critérios segundo EMBRAPA (2006).

Após vetorizados os mapas no SPRING 5.1, estes foram exportados no formato shapefile para posterior importação no ArcGIS 9.3, a partir de qual foi dado o acabamento e finalização dos mapas temáticos de caracterização do meio físico da bacia.

\subsection{Obtenção de dados por meio de imagens de sensoriamento remoto}

Para obtenção das informações relativas à cobertura e uso do solo na área de estudo, recorreu-se ao processo de classificação supervisionada de imagens multiespectrais utilizando-se uma cena obtida a partir do satélite CBERS-2B, cuja resolução espacial é de 20 metros. A imagem utilizada foi disponibilizada por meio do site do Instituto Nacional de 
Pesquisas Espaciais - INPE, sendo adquirida na data de 2 de fevereiro de 2010, órbita 155/ ponto 125 .

Realizou-se o georreferenciamento e tratamento da imagem no software SPRING 5.1 e, em seguida, procedeu-se a classificação desta imagem selecionando-se as bandas espectrais 1, 2, 3 e 4. Utilizou-se o método de classificação supervisionado por pixel, onde foram indicadas amostras dos tipos de coberturas/usos existentes na bacia, a partir das quais o software detectou, através de algoritmos estatísticos, pixels com assinaturas espectrais semelhantes aos pixels das amostras. Foi utilizado neste processo o classificador por máxima verossimilhança Maxver, com limiar de aceitação de $99 \%$.

As classes de cobertura definidas na etapa de treinamento foram: mata, reflorestamento, cana-de-açúcar, citricultura, pastagem, campo/cerrado, água e solo exposto. As classes área urbanizada, área urbanizada de baixa densidade e área sujeita à inundação foram vetorizadas separadamente sob a imagem de satélite e inseridas ao final da classificação.

Depois do processamento das imagens, foi realizado o refinamento e aferição do resultado através de sua comparação visual com imagens de alta resolução disponíveis no software Google Earth, bem como foram realizadas verificações em campo, de modo a corrigir possíveis inconsistências ocorridas durante o processo de classificação.

\subsection{Modelagem da produção de sedimentos utilizando o simulador SWAT}

Para as operações de modelagem da produção de sedimentos, utilizou-se a ferramenta ArcSWAT 2009.93.7b, uma extensão para ArcGIS 9.3 que integra o SIG com o modelo SWAT, permitindo que a entrada dos dados seja realizada através de uma interface disponível no próprio software.

Por ser um modelo que opera na escala de bacia hidrográfica, o SWAT trabalha com uma grande quantidade de dados e parâmetros, espaciais e não espaciais, de maneira que seja possível representar toda a heterogeneidade existente nos sistemas modelados. Desse modo, são requeridos pelo modelo dados de entrada geoespaciais, numéricos e de texto, referentes aos tipos de solo, ao tipo de cobertura, à topografia, ao clima, dentre outros. Nas seções seguintes serão apresentados os procedimentos realizados para obtenção de tais entradas, bem como serão descritas as etapas envolvidas no processo de simulação. 


\subsubsection{Delineamento da bacia de drenagem e definição do número de sub-bacias}

A etapa inicial de simulação no SWAT consiste na delimitação da bacia de drenagem e na sua divisão em sub-bacias, as quais são tratadas como unidades independentes no processo de modelagem. Para tal, nesta primeira etapa o simulador requer como dado de entrada o Modelo Digital de Elevação (Digital Elevation Model - DEM) envolvendo a área da bacia.

Para geração do DEM, foram utilizadas as curvas de nível, cuja equidistância é de 5 metros, e os pontos cotados previamente digitalizados. Através das ferramentas disponíveis na extensão 3D Analyst Tools do ArcGIS, obteve-se por meio de triangulação uma Grade Irregular Triangular (Triangulated Irregular Network - TIN), a qual foi convertida para o formato raster. O tamanho de pixel escolhido para o DEM foi de 10 metros, originando um raster de 2319 linhas por 2598 colunas, representando não somente os limites da bacia, mas também suas áreas subjacentes.

Após inserido o DEM, o usuário tem a opção de adicionar a rede hidrográfica a partir de um arquivo previamente preparado ou deixar que o modelo a gere automaticamente tendo como base o DEM. Neste trabalho, optou-se por utilizar a rede de drenagem obtida por meio da vetorização das cartas topográficas do IGC, cuja escala é de 1:10.000.

No processo de divisão das sub-bacias, o simulador adiciona automaticamente os pontos de confluência da rede hidrográfica, os quais representam os exutórios referentes a cada sub-bacia, tendo como base a rede hidrográfica. A partir do DEM é realizada a determinação da direção do fluxo para cada pixel, permitindo delimitar a área que contribui com o escoamento superficial para cada ponto da rede hidrográfica. Nesta etapa, também é permitido ao usuário inserir ou remover pontos de interesse, podendo desta forma definir o número de sub-bacias a serem geradas.

\subsubsection{Dados pedológicos}

Em relação aos dados de entrada referentes aos solos, o simulador exige tanto dados espaciais, representando a distribuição dos tipos de solo na bacia, quanto dados tabulares. Foi utilizado o mapa de solos da EMPRAPA (1981), previamente vetorizado no SPRING, o qual foi importado para o ArcGIS 9.3 por meio da interface do SWAT.

Os dados tabulares exigidos pelo modelo são relativos a cada uma das classes de solo existentes no mapa, sendo que tais valores podem ser obtidos a partir da literatura ou 
estimados. Segundo Neitsch et al. (2005), tais parâmetros refletem as características físicas do solo, as quais governam o movimento da água e ar através do perfil do solo e tem importante impacto na circulação da água dentro de uma sub-bacia. Estes parâmetros são apresentados na Tabela 1, juntamente com a fonte de qual foram obtidos.

Tabela 1 - Parâmetros relativos aos solos exigidos pelo SWAT

\begin{tabular}{|c|c|c|}
\hline Parâmetro & Descrição & Fonte \\
\hline NLAYERS & Número de camadas do perfil & Oliveira e Prado (1984) \\
\hline HYDGRP & Grupo hidrológico & Lombardi Neto et al. (1989) \\
\hline SOL_ZMX & Profundidade máx. da raiz no solo (mm) & Oliveira e Prado (1984) \\
\hline ANION_EXCL & Porosidade do solo (fração) & Oliveira e Prado (1984) \\
\hline SOL_Z* & Profundidade de cada horizonte (mm) & Oliveira e Prado (1984) \\
\hline SOL_BD* & Densidade aparente $\left(\mathrm{g} / \mathrm{cm}^{3}\right)$ & Oliveira e Prado (1984) \\
\hline SOL_AWC & Capacidade de água disponível (mm/mm) & Saxton e Rawls (2006) \\
\hline SOL_CBN $^{*}$ & Teor de carbono orgânico (\% peso do solo) & Oliveira e Prado (1984) \\
\hline SOL_K ${ }^{*}$ & Condutividade hidráulica saturada (mm/h) & Saxton e Rawls (2006) \\
\hline CLAY $^{*}$ & Porcentagem de argila ( $\%$ peso do solo) & Oliveira e Prado (1984) \\
\hline SILT $^{*}$ & Porcentagem de silte (\% peso do solo) & Oliveira e Prado (1984) \\
\hline SAND* & Porcentagem de areia (\% peso do solo) & Oliveira e Prado (1984) \\
\hline ROCK $^{*}$ & Porcentagem de cascalho ( $\%$ peso do solo) & Oliveira e Prado (1984) \\
\hline SOL_ALB ${ }^{*}$ & Albedo do solo (fração) & Freire et al. (1978) \\
\hline USLE_K ${ }^{*}$ & Fator K da USLE & Williams (1995) \\
\hline
\end{tabular}

* Parâmetros relativos a cada uma das camadas do perfil de solo

É importante frisar que com exceção dos parâmetros NLAYERS, HYDGRP, SOL_ZMX e ANION_EXCL, os demais devem ser específicos para cada uma das camadas do perfil de solo. Para diferenciar os parâmetros relativos a cada camada dentro das rotinas do simulador, é adicionado o algarismo referente ao número da camada após a sigla do parâmetro. Assim, para a densidade aparente da primeira camada de solo, tem-se SOL_BD1, para a segunda camada, SOL_BD2, e assim sucessivamente.

Os parâmetros número de camadas do perfil (NLAYERS), profundidade máxima da raiz no solo (SOL_ZMX), porosidade do solo (ANION_EXCL), profundidade de cada horizonte (SOL_Z), densidade aparente (SOL_BD), teor de carbono orgânico (SOL_CBN) e porcentagens de argila (CLAY), silte (SILT), areia (SAND) e cascalho (ROCK) foram 
extraídos do memorial descritivo referente ao mapa de solos utilizado (OLIVEIRA e PRADO, 1984), no qual os autores analisaram um grande número de perfis de solo no interior e no entorno da área de estudo.

Em relação ao parâmetro profundidade máxima da raiz no solo (SOL_ZMX), não foram encontrados dados obtidos em campo para a área de estudo, portanto, assumiu-se que as raízes podem se desenvolver por toda a profundidade da camada do solo.

Para o parâmetro HYDGRP, referente ao grupo hidrológico do solo, utilizou-se a classificação hidrológica para os solos do estado de São Paulo proposta por Lombardi Neto et al. (1989), apresentada no Quadro 3.

Nesta classificação, os autores estabeleceram quatro grupos de solos de acordo com suas características físicas, visando sua aplicação em práticas conservacionistas. Os solos encontrados na bacia foram enquadrados nestes grupos levando em consideração a profundidade, a permeabilidade, a textura da camada superficial e subsuperficial e a relação textural da argila entre os horizontes A e B.

O parâmetro fração de porosidade do solo (ANION_EXC) representa a relação entre o volume ocupado pelos poros e o volume total do solo. Tal parâmetro foi calculado através da relação entre a densidade aparente, ou seja, a densidade considerando o somatório de volume das partículas e dos poros, e a densidade real do solo, de acordo com a equação 21.

$$
\text { ANION_EXCL }=1-\left(\frac{\rho_{\mathrm{b}}}{\rho_{\mathrm{s}}}\right)
$$

Onde:

$\rho_{\mathrm{b}}=$ densidade aparente do solo $\left(\mathrm{g} / \mathrm{cm}^{3}\right)$

$\rho_{\mathrm{s}}=$ densidade real ou densidade das partículas do solo $\left(\mathrm{g} / \mathrm{cm}^{3}\right)$

Os dados referentes às densidades real e aparente das camadas foram extraídos dos levantamentos de campo realizados por Oliveira e Prado (1984). Para as camadas onde não havia a medição da densidade real em campo, adotou-se o valor de $2,65 \mathrm{~g} / \mathrm{cm}^{3}$, visto que a densidade dos principais componentes minerais dos solos (quartzo, feldspatos e argilas silicatadas) está próxima deste valor. 
Quadro 3 - Classificação hidrológica do solo para as condições brasileiras e enquadramento das principais classes de solos

\begin{tabular}{|c|c|c|}
\hline GH & Principais características & Classes gerais de solo \\
\hline A & $\begin{array}{l}\text { - Solos muito profundos (>200 cm) ou profundos }(100-200 \mathrm{~cm}) \text {; } \\
\text { - Com alta taxa de infiltração e alto grau de resistência à erosão; } \\
\text { - Solos porosos com baixo gradiente textural }(<1,20) \text {; } \\
\text { - Solos de textura média; } \\
\text { - Solos de textura argilosa ou muito argilosa, desde que a } \\
\text { estrutura proporcione alta macroporosidade em todo perfil; } \\
\text { - Solos bem drenados ou excessivamente drenados; } \\
\text { - Com argila de atividade baixa (Tb), minerais de argila } 1: 1 \text {; } \\
\text { - A textura dos horizontes superficial e subsuperficial pode ser: } \\
\text { média/media, argilosa/argilosa e muito argilosa/muito argilosa. }\end{array}$ & $\begin{array}{l}\text { - Latossolo amarelo, Latossolo } \\
\text { vermelho-amarelo, Latossolo } \\
\text { vermelho, todos de textura } \\
\text { argilosa ou muito argilosa e com } \\
\text { alta macroporosidade; } \\
\text { - Latossolo amarelo e Latossolo } \\
\text { vermelho amarelo, ambos de } \\
\text { textura média, mas com horizonte } \\
\text { superficial não arenoso. }\end{array}$ \\
\hline $\mathrm{B}$ & $\begin{array}{l}\text { - Solos profundos (100 a } 200 \mathrm{~cm}) \text {; } \\
\text { - Solos com moderada taxa de infiltração, mas com moderada } \\
\text { resistência e tolerância à erosão; } \\
\text { - Solos porosos com gradiente textural variando entre } 1,2 \text { e } 1,5 \text {; } \\
\text { - Solos de textura arenosa ao longo do perfil ou de textura média, } \\
\text { mas com horizonte superficial arenoso; } \\
\text { - Solos com textura argilosa ou muito argilosa, desde que a } \\
\text { estrutura proporcione boa macroporosidade em todo perfil } \\
\text { - Com argila de atividade baixa (Tb), minerais de argila } 1: 1 \text {; } \\
\text { - A textura dos horizontes superficial e subsuperficial pode ser: } \\
\text { arenosa/arenosa, arenosa/média, média/argilosa, } \\
\text { argilosa/argilosa e argilosa/muito argilosa. }\end{array}$ & $\begin{array}{l}\text { - Latossolo amarelo e Latossolo } \\
\text { vermelho amarelo, ambos de } \\
\text { textura média, mas com horizonte } \\
\text { superficial de textura arenosa; } \\
\text { - Latossolo Bruno; } \\
\text { - Nitossolo vermelho; } \\
\text { - Neossolo Quartzarênico; } \\
\text { - Argissolo vermelho ou vermelho } \\
\text { amarelo de textura arenosa/média, } \\
\text { média/argilosa, argilosa/argilosa } \\
\text { ou argilosa/muito argilosa que } \\
\text { não apresentam mudança textural } \\
\text { abrupta. }\end{array}$ \\
\hline $\mathrm{C}$ & $\begin{array}{l}\text { - Solos profundos (100 a } 200 \mathrm{~cm}) \text { ou pouco profundos }(50 \text { - } 100 \\
\mathrm{cm}) \text {; } \\
\text { - Solos com baixa taxa de infiltração e baixa resistência à erosão; } \\
\text { - Solos com gradiente textural maior que } 1,5 \text { e comumente } \\
\text { apresentam mudança textural abrupta; } \\
\text { - Solos associados à argila de atividade baixa }(\mathrm{Tb}) \text {; } \\
\text { - A textura nos horizontes superficial e subsuperficial pode ser: } \\
\text { arenosa/media e média/argilosa apresentando mudança textural } \\
\text { abrupta; arenosa/argilosa e arenosa/muito argilosa. }\end{array}$ & $\begin{array}{l}\text { - Argissolos pouco profundos, mas } \\
\text { não apresentando mudança } \\
\text { textural abrupta; } \\
\text { - Argissolo vermelho, Argissolo } \\
\text { vermelho amarelo e Argissolo } \\
\text { amarelo, profundos e com } \\
\text { mudança textural abrupta; } \\
\text { - Cambissolo de textura média e } \\
\text { Cambissolo Háplico ou Húmico, } \\
\text { mas com características físicas } \\
\text { semelhantes aos Latossolos; } \\
\text { - Espodossolos ferrocárbico; } \\
\text { - Neossolo Flúvico. }\end{array}$ \\
\hline $\mathrm{D}$ & $\begin{array}{l}\text { - Solos com taxa de infiltração muito baixa oferecendo } \\
\text { pouquíssima resistência E tolerância à erosão; } \\
\text { - Solos rasos }(<50 \mathrm{~cm}) \text {; } \\
\text { - Solos pouco profundos associados à mudança textural abrupta } \\
\text { aliada à argila de alta atividade }(\mathrm{Ta}) \text {, minerais de argila } 2: 1 ; \\
\text { - Solos argilosos associados à argila de atividade alta }(\mathrm{Ta}) \text {; } \\
\text { - Solos orgânicos. }\end{array}$ & $\begin{array}{l}\text { - Neossolo Litólico; Organossolo; } \\
\text { Gleissolo; Chernossolo; } \\
\text { Planossolo; Vertissolo; Alissolo; } \\
\text { Luvissolo; Plintossolo; } \\
\text { - Solos de mangue; } \\
\text { - Afloramentos de rocha; } \\
\text { - Demais Cambissolos que não se } \\
\text { enquadram no grupo C; } \\
\text { - Argissolo vermelho amarelo e } \\
\text { Argissolo amarelo, ambos pouco } \\
\text { profundos e associados à } \\
\text { mudança textural abrupta. }\end{array}$ \\
\hline
\end{tabular}

Fonte: Adaptado de Lombardi Neto et al. (1989). 
O parâmetro capacidade de água disponível (SOL_AWC), juntamente com a condutividade hidráulica saturada (SOL_K) são indicadores de solo largamente usados para avaliar potencialidades dentro do campo da agricultura, bem como para fins de manejo ambiental de uma determinada região (SANTOS, 2010). Neste trabalho, tais parâmetros foram estimados a partir de sua relação com as características texturais e o teor carbono orgânico, segundo metodologia apresentada por Saxton e Rawls (2006).

O parâmetro Fator K da USLE (USLE_K) refere-se à suscetibilidade de um determinado solo à erosão, representando a facilidade com o qual este pode ser erodido. Alguns solos são mais erodíveis que outros, mesmo quando o declive, a precipitação, a cobertura vegetal e as práticas de controle de erosão são as mesmas. Essa diferença ocasionada pelas propriedades inerentes ao solo é referida como erodibilidade do solo. (BERTONI e LOMBARDI NETO, 2005).

Tal parâmetro foi calculado através da metodologia proposta por Williams (1995), a qual estima valores de erodibilidade com base nas características texturais e no teor de carbono orgânico do solo segundo a equação 22.

$$
\mathrm{K}_{\text {USLE }}=\mathrm{f}_{\text {csand }} \cdot \mathrm{f}_{\mathrm{cl}-\mathrm{si}} \cdot \mathrm{f}_{\text {orgC }} \cdot \mathrm{f}_{\text {hisand }}
$$

Onde:

$\mathrm{f}_{\text {csand }}=$ fração de solos com alto conteúdo de areia grossa (equação 23)

$$
\mathrm{f}_{\mathrm{csand}}=\left\{0,2+0,3 \exp \left[-0,256 \cdot \mathrm{m}_{\mathrm{s}}\left(1-\frac{\mathrm{m}_{\text {silt }}}{100}\right)\right]\right\}
$$

$\mathrm{f}_{\mathrm{cl}-\mathrm{si}}=$ fração de solos com alta razão de silte e argila (equação 24)

$$
\mathrm{f}_{\mathrm{cl}-\mathrm{si}}=\left(\frac{\mathrm{m}_{\text {silt }}}{\mathrm{m}_{\mathrm{silt}}+\mathrm{m}_{\mathrm{c}}}\right)^{0,3}
$$

$\mathrm{f}_{\text {orgC }}=$ fração de solos com alto conteúdo de carbono orgânico (equação 25)

$$
\mathrm{f}_{\mathrm{orgC}}=1-\frac{0,25 \cdot \operatorname{orgC}}{\operatorname{orgC}+\exp (3,72-2,95 \cdot \operatorname{orgC})}
$$


$f_{\text {hisand }}=$ fração de solos com conteúdo extremamente alto de areia (equação 26)

$$
\mathrm{f}_{\text {hisand }}=1-\frac{0,7 \cdot\left(1-\frac{\mathrm{m}_{\mathrm{s}}}{100}\right)}{\left(1-\frac{\mathrm{m}_{\mathrm{s}}}{100}\right)+\exp \left[-5,51+22,9 \cdot\left(1-\frac{\mathrm{m}_{\mathrm{s}}}{100}\right)\right]}
$$

Para as equações 23, 24, 25 e 26, têm-se:

$$
\begin{aligned}
& \mathrm{m}_{\mathrm{s}}=\text { fração de areia (diâmetro 0,05 a 2,00 mm) } \\
& \mathrm{m}_{\text {silt }}=\text { fração de silte (diâmetro 0,002 a 0,05mm) } \\
& \mathrm{m}_{\mathrm{c}}=\text { fração de argila (diâmetro < 0,002 mm) } \\
& \text { orgC = percentual de carbono orgânico na camada }
\end{aligned}
$$

O albedo é a parcela da radiação solar que é refletida de volta para a atmosfera ao atingir a superfície do solo, considerando sua cobertura vegetal. O parâmetro albedo do solo (SOL_ALB) foi obtido através dos trabalhos de Freire et al. (1978), no qual os autores realizaram a caracterização de diversos atributos físico-químicos referentes aos solos da bacia de estudo.

Os quinze parâmetros obtidos nesta etapa foram adicionados manualmente ao banco de dados do SWAT através da interface disponível no ArgGIS 9.3, sendo adicionadas as entradas referentes aos tipos de solos existentes no mapa pedológico utilizado.

\subsubsection{Dados climáticos}

O SWAT tem como processo chave em sua modelagem a simulação do balanço hídrico em uma bacia hidrográfica, a partir do qual são simulados os processos de perda de solo e transporte de sedimentos e poluentes. Desse modo, a inserção de parâmetros climáticos é de fundamental importância no processo de modelagem hidrológica, visto que estes são responsáveis por reger as etapas do balanço hídrico.

Os dados climáticos utilizados foram cedidos pela estação meteorológica situada no Centro de Recursos Hídricos e Ecologia Aplicada (CRHEA), localizada no interior da bacia, nas proximidades de seu exutório $(201.156 \mathrm{~m} \mathrm{E}, 7.545 .471 \mathrm{~m} \mathrm{~N}, 732 \mathrm{~m}$ de altitude). Foi 
utilizada uma série de dados relativa ao período entre 01/01/1992 e 31/12/2011, representando um total de 20 anos contínuos.

Para o processo de simulação, o SWAT requer que sejam informados tanto dados diários como dados mensais. Em relação aos primeiros, foram inseridos valores diários de precipitação $\left(\mathrm{mm} \mathrm{H}_{2} \mathrm{O}\right)$, de temperatura máxima e mínima $\left({ }^{\circ} \mathrm{C}\right)$, de radiação solar $\left(\mathrm{MJ} / \mathrm{m}^{2}\right.$.dia), de umidade relativa $(\%)$ e de velocidade do vento $(\mathrm{m} / \mathrm{s})$.

Caso algum dos parâmetros diários não esteja disponível, o SWAT permite que os estes sejam simulados a partir dos dados de chuva por meio do gerador climático WXGEN (Sharpley e Williams, 1990), o qual utiliza os parâmetros mensais para simular dados diários. Além de simular séries históricas diárias, tal gerador também é usado para o preenchimento de falhas nos dados registrados. Neste trabalho, não foi necessário realizar tal simulação, visto que haviam disponíveis séries diárias completas para todos os parâmetros necessários.

Na Tabela 2 são apresentados os dados mensais exigidos pelo SWAT. Tais parâmetros são também utilizados pelo gerador WXGEN nos casos em que não existem séries de dados diários, conforme citado anteriormente.

Tabela 2 - Dados climáticos mensais exigidos pelo SWAT

\begin{tabular}{lr}
\hline \multicolumn{1}{c}{ Parâmetro } & Descrição \\
\hline TMPMX & Média mensal de temperatura máxima diária $\left({ }^{\circ} \mathrm{C}\right)$ \\
TMPMN & Média mensal de temperatura mínima diária $\left({ }^{\circ} \mathrm{C}\right)$ \\
TMPSTDMX & Desvio padrão para a temperatura máxima diária de cada mês \\
TMPSTDMN & Desvio padrão para a temperatura mínima diária de cada mês \\
PCPMM & Média mensal da precipitação total (mm) \\
PCPSTD & Desvio padrão para a precipitação diária do mês \\
PCCSKW & Coeficiente de assimetria para a precipitação diária por mês \\
PR_W1 & Probabilidade de dias úmidos seguidos de dias secos para o mês \\
PR_W2 & Probabilidade de dias úmidos seguidos de dias úmidos para o mês \\
PCPD & Média mensal de dias de precipitação no mês \\
RAINHHMX & Valor máximo de $0,5 \mathrm{~h}$ de chuva em todo o período de registros do mês $(\mathrm{mm})$ \\
SOLARAV & Média diária de radiação solar para determinado mês $\left(\mathrm{MJ} / \mathrm{m}^{2} / \mathrm{dia}\right)$ \\
DEWPT & Média diária do ponto de orvalho para determinado mês $\left({ }^{\circ} \mathrm{C}\right)$ \\
WNDAV & Média diária da velocidade do vento para determinado mês $(\mathrm{m} / \mathrm{s})$
\end{tabular}


Para determinação dos parâmetros apresentados na Tabela 2, foi utilizada a planilha de cálculo automatizado WGN Excel Macro, disponibilizada no site do SWAT. Os dados de entrada requeridos para tal aplicação são séries históricas diárias dos valores de precipitação, temperatura máxima e mínima, radiação solar, velocidade do vento, temperatura do ponto de orvalho $^{1}$ e valor máximo de chuva em 30 minutos.

Os valores de precipitação, temperatura máxima e mínima, radiação solar e velocidade do vento utilizados no WGN Excel Macro foram obtidos a partir da estação climatológica do CRHEA, sendo utilizada a mesma série de dados de 20 anos indicada ao SWAT na alimentação dos dados diários.

O cálculo da temperatura do ponto de orvalho, necessária para determinação do parâmetro DEWPT, foi executado a partir dos dados de umidade relativa e temperatura do ar. A umidade relativa do ar (UR\%) é dada pela relação entre a quantidade de vapor existente no ar e a que existiria se o mesmo estivesse saturado na mesma temperatura.

$$
\mathrm{UR}(\%)=\frac{e_{a}}{e_{s}} \cdot 100 \quad \text { ou } \quad e_{a}=\mathrm{UR} \cdot e_{s}
$$

Onde:

$e_{a}=$ pressão real de vapor de água no ar $(\mathrm{kPa})$

$e_{s}=$ pressão de saturação do vapor $(\mathrm{kPa})$

A quantidade máxima de vapor d'água no ar pode ser descrita em função da temperatura ambiente. A relação de dependência entre a pressão exercida pelo teor saturante de vapor d'água e a temperatura do ar $\left(\mathrm{t}_{\mathrm{ar}}\right)$ é descrita pela equação de Tetens.

$$
e_{s}=0,6108 \cdot \exp \left[\frac{7,5 \cdot \mathrm{t}_{\mathrm{ar}}}{\left(237,3+\mathrm{t}_{\mathrm{ar}}\right)}\right]
$$

\footnotetext{
${ }^{1}$ Ponto de orvalho é a temperatura à qual o vapor de água presente no ar ambiente passa ao estado líquido na forma de pequenas gotas.
} 
Assim, de posse dos valores de $e_{a}$ e $e_{s}$, calcula-se a temperatura de ponto de orvalho (DEWPT), através da equação 29.

$$
\mathrm{DEWPT}=\frac{\left[237,3 \cdot \log \left(\frac{e_{a}}{0,6108}\right)\right]}{\left[7,5-\log \left(\frac{e_{s}}{0,6108}\right)\right]}
$$

A obtenção do valor máximo de chuva em 30 minutos, necessário para obtenção do parâmetro RAINHHMX, se deu por método indireto, realizando-se estimativas utilizando os dados diários de precipitação.

Segundo Bertoni e Tucci (1993), a partir da chuva total diária, podem-se obter chuvas de 24 horas de duração com determinada frequência e desagregá-las para durações menores, utilizando os chamados coeficientes de desagregação de chuvas. Esta prática é usada, normalmente, para estabelecer relações de intensidade-duração-frequência (IDF) em locais que dispõem somente de dados diários medidos com pluviômetros convencionais.

$\mathrm{Na}$ Tabela 3 são apresentados os coeficientes de desagregação de chuva propostos pela CETESB (1980), obtidos a partir do estudo de chuvas intensas de Pfafstetter (1982), que abrangeu todo o território nacional. Tais valores são relações médias de precipitação máxima com períodos de retorno entre 2 e 100 anos obtidas das curvas IDF deste último autor. Podese notar um grupo de índices relativos a durações menores que 30 minutos e outro para durações iguais ou superiores a 1 hora. O coeficiente que relaciona a chuva de 30 minutos com a chuva de 1 hora é o elo entre os dois grupos (SILVEIRA, 2000).

Tabela 3 - Coeficientes de desagregação de chuvas de 24 horas de duração

\begin{tabular}{cccc}
\hline Duração & Coeficientes & Duração & Coeficientes \\
\hline $1 \mathrm{dia} / 24 \mathrm{~h}$ & 1,14 & $30 \mathrm{~min} / 1 \mathrm{~h}$ & 0,74 \\
$12 \mathrm{~h} / 24 \mathrm{~h}$ & 0,85 & $25 \mathrm{~min} / 30 \mathrm{~min}$ & 0,91 \\
$10 \mathrm{~h} / 24 \mathrm{~h}$ & 0,82 & $20 \mathrm{~min} / 30 \mathrm{~min}$ & 0,81 \\
$08 \mathrm{~h} / 24 \mathrm{~h}$ & 0,78 & $15 \mathrm{~min} / 30 \mathrm{~min}$ & 0,70 \\
$06 \mathrm{~h} / 24 \mathrm{~h}$ & 0,72 & $10 \mathrm{~min} / 30 \mathrm{~min}$ & 0,54 \\
$01 \mathrm{~h} / 24 \mathrm{~h}$ & 0,42 & $05 \mathrm{~min} / 30 \mathrm{~min}$ & 0,34 \\
\hline
\end{tabular}

Fonte: DAEE/CETESB (1980) 
Utilizando-se a Tabela 3, obteve-se a chuva de 30 minutos a partir da chuva de 1 dia através da sequência de coeficientes em cascata igual a 1,14 multiplicado por 0,42 e por 0,74, gerando um coeficiente igual a 0,354. Desse modo, a chuva máxima de 30 minutos corresponde a 0,354 (ou 35,4\%) da chuva medida em um dia. Tal coeficiente foi aplicado à série de dados diários de precipitação, podendo desta forma ser utilizada para cálculo do parâmetro RAINHHMX.

Depois de obtidos todos os parâmetros mensais, estes foram digitados diretamente no banco de dados do SWAT através de sua interface com o ArcGIS 9.3, bem como foram inseridas as séries históricas de dados diários.

\subsubsection{Dados de uso da terra}

De modo semelhante às informações referentes aos solos, os dados referentes aos tipos de cobertura do solo necessários para alimentação do modelo constituem dados espaciais e tabulares. Como dado espacial, utilizou-se o mapa de uso e ocupação produzido anteriormente através de classificação supervisionada de uma imagem CBERS-2B, cujos procedimentos foram apresentados na seção 5.2.

Na Tabela 4 são apresentados os dados tabulares necessários para a caracterização dos tipos de cobertura do solo exigidos pelo SWAT. Por serem atributos de caracterização complexa e de grande dificuldade de obtenção na literatura, optou-se por utilizar as categorias de cobertura do solo existentes no banco de dados do SWAT, as quais já possuem tais atributos definidos. 
Tabela 4 - Parâmetros de cobertura do solo e crescimento da vegetação

\begin{tabular}{|c|c|}
\hline Parâmetro & Descrição \\
\hline IDC & Classificação da cobertura \\
\hline BIO_E & Eficiência uso-radiação ou taxa biomassa-energia $\left[(\mathrm{kg} / \mathrm{ha}) /\left(\mathrm{MJ} / \mathrm{m}^{2}\right)\right]$ \\
\hline HVSTI & Índice de colheita para condições ótimas de crescimento $[(\mathrm{kg} / \mathrm{ha}) /(\mathrm{kg} / \mathrm{ha})]$ \\
\hline BLAI & Índice de máxima área foliar potencial $\left(\mathrm{m}^{2} / \mathrm{m}^{2}\right)$ \\
\hline FRGRW1 & $\begin{array}{l}\text { Fração da estação de crescimento da planta ou fração de unidades de calor potencial total } \\
\text { correspondente ao primeiro ponto da curva de desenvolvimento ótimo da área foliar }\end{array}$ \\
\hline LAIMX1 & $\begin{array}{c}\text { Fração do índice de máxima área foliar correspondente ao primeiro ponto da curva de } \\
\text { desenvolvimento ótimo da área foliar }\end{array}$ \\
\hline FRGRW2 & $\begin{array}{l}\text { Fração da estação de crescimento da planta ou fração de unidades de calor potencial total } \\
\text { correspondente ao segundo ponto da curva de desenvolvimento ótimo da área foliar }\end{array}$ \\
\hline LAIMX2 & $\begin{array}{c}\text { Fração do índice de máxima área foliar correspondente ao segundo ponto da curva de } \\
\text { desenvolvimento ótimo da área foliar }\end{array}$ \\
\hline DLAI & Fração da estação de crescimento quando a área foliar começa a decair \\
\hline CHTMX & Altura máxima da copa $(\mathrm{m})$ \\
\hline RDMX & Profundidade máxima da raiz (m) \\
\hline T_OPT & Temperatura ótima para crescimento da planta $\left({ }^{\circ} \mathrm{C}\right)$ \\
\hline T_BASE & Temperatura mínima (base) para crescimento da planta $\left({ }^{\circ} \mathrm{C}\right)$ \\
\hline CNYLD & Fração normal de nitrogênio em produção (kg N/kg yield) \\
\hline CPYLD & Fração normal de fósforo em produção (kg P/kg yield) \\
\hline WSYF & Limite mínimo do índice de colheita $[(\mathrm{kg} / \mathrm{ha}) /(\mathrm{kg} / \mathrm{ha})]$ \\
\hline USLE_C & Valor mínimo do fator C da USLE \\
\hline GSI & Máx. condutância estomatal à alta radiação solar e baixo déficit de pressão de vapor (m/s) \\
\hline VPDFR & $\begin{array}{l}\text { Déficit de pressão de vapor correspondente ao segundo ponto da curva de condutância } \\
\text { estomatal }(\mathrm{kPa})\end{array}$ \\
\hline FRGMAX & $\begin{array}{c}\text { Fração de máxima condutância estomatal correspondente ao segundo ponto da curva de } \\
\text { condutância }\end{array}$ \\
\hline WAVP & $\begin{array}{c}\text { Taxa de declínio na eficiência do uso de radiação por unidade de aumento do déficit de } \\
\text { pressão de vapor }\end{array}$ \\
\hline $\mathrm{CO} 2 \mathrm{HI}$ & $\begin{array}{l}\text { Concentração de } \mathrm{CO}_{2} \text { atmosférico correspondente ao segundo ponto da curva de eficiência } \\
\text { do uso de radiação }\left(\mu \mathrm{L} \mathrm{CO}_{2} / \mathrm{L} \text { air }\right)\end{array}$ \\
\hline BIOEHI & $\begin{array}{l}\text { Taxa biomassa-energia correspondente ao segundo pronto da curva de eficiência do uso da } \\
\text { radiação }\end{array}$ \\
\hline RSDCO_PL & Coeficiente de resíduo da decomposição da planta \\
\hline ALAI_MIN & Índice de mínima área foliar para planta durante o período de dormência $\left(\mathrm{m}^{2} / \mathrm{m}^{2}\right)$ \\
\hline BIO_LEAF & $\begin{array}{c}\text { Fração da biomassa das árvores acumulada cada ano e que é convertida em resíduo durante } \\
\text { a dormência }\end{array}$ \\
\hline MAT_YRS & $\begin{array}{l}\text { Número de anos necessário para as espécies de árvores atingirem o desenvolvimento pleno } \\
\text { (anos) }\end{array}$ \\
\hline BMX_TREES & Biomassa máxima para floresta (tons/ha) \\
\hline EXT_COEF & Coeficiente de extinção de luz \\
\hline
\end{tabular}


A versão 2009 do SWAT apresenta em seu banco de dados 110 categorias de cobertura relacionadas a diversos tipos de uso do solo e de culturas agrícolas, onde estão inseridos em seu default os valores para os parâmetros referentes a cada categoria de uso. Para as áreas urbanizadas, o simulador também apresenta diferentes categorias relacionadas ao tipo de urbanização e ao grau de impermeabilização.

Desse modo, para cada um dos tipos de cobertura presentes no mapa de uso e ocupação gerado, foram associadas categorias presentes no banco de dados do simulador. $\mathrm{Na}$ Tabela 5 é apresentada tal associação, na qual se tentou manter o maior nível de similaridade possível entre as classes em relação à sua estrutura e físionomia.

Tabela 5 - Associação entre as classes de uso e ocupação do solo da bacia e os tipos de cobertura do solo disponíveis no banco de dados do SWAT

\begin{tabular}{lc}
\hline \multicolumn{1}{c}{ Classes de uso e ocupação na bacia } & Classes no banco de dados do SWAT \\
\hline Mata & Forest-Mixed (FRST) \\
Campo/cerrado & Range-Grasses (RNGE) \\
Pastagem & Pasture (PAST) \\
Reflorestamento & Pine (PINE) \\
Cana-de-açúcar & Sugarcane (SUGC) \\
Citricultura & Orange (ORAN) \\
Outras culturas & Agricultural Land-Generic (AGRL) \\
Área urbanizada & Residential (URBN) \\
Área urbanizada de baixa densidade & Residential-Low Density (URLD) \\
Área sujeita à inundação & Wetlands-Non-Forested (WETN) \\
Água & Water (WATR) \\
\hline
\end{tabular}

\subsubsection{Definição das Unidades de Resposta Hidrológica (HRU)}

Depois da delimitação das sub-bacias e inserção dos dados pedológicos, climáticos e de cobertura da terra no banco de dados do SWAT, o próximo passo é a definição das Unidades de Resposta Hidrológica (HRU) a serem adotadas nas sub-bacias.

Segundo Winchell (2009), a subdivisão da bacia em áreas com uma combinação única de tipo de solo e cobertura permite ao modelo enfatizar as diferenças na evapotranspiração e 
nas demais condições hidrológicas. O escoamento superficial é simulado separadamente para cada HRU e propagado cumulativamente de modo a se obter o escoamento total para cada sub-bacia. Tal procedimento aumenta a precisão da simulação hidrológica e fornece uma descrição física mais realista do balanço hídrico.

A formação das HRU se dá através da combinação das características pedológicas, dos tipos de uso do solo e das faixas de declividade, por meio de uma operação de superposição de planos de informação. De acordo com Minotti (2006), nesta fase o usuário pode escolher entre duas opções de combinações para definição das HRU:

I. HRU dominante: em cada sub-bacia, o uso da terra, o tipo de solo e a classe de declividade que apresentarem maior extensão, ou seja, forem predominantes, serão considerados para toda a área da sub-bacia, sendo os demais tipos descartados;

II. Múltiplas HRU: serão criadas várias combinações de tipos de solo, usos do solo e classes de declividade para cada sub-bacia, de acordo com o nível de sensibilidade escolhido pelo usuário do programa, as quais serão utilizadas para determinar o número e o tipo de HRU em cada sub-bacia.

Ao se trabalhar com múltiplas HRU, é permitido ao usuário definir limiares de exclusão para as classes de solo, classes de cobertura e classes de declividade, podendo tais limiares serem definidos em relação a porcentagem da classe na sub-bacia ou em relação a sua área. Por meio deste procedimento, é permitido definir o nível de detalhamento de representação das sub-bacias, onde o usuário pode, por exemplo, ignorar usos do solo cuja extensão seja menor que determinada porcentagem da sub-bacia.

Neste trabalho, utilizou-se a opção de múltiplas HRU por sub-bacia, com o intuito de manter um maior detalhamento e evitar a perda ou alteração das informações de entrada. Optou-se por aplicar um limiar de exclusão de 5\% para o tipo de solo, $10 \%$ para o tipo de cobertura e 5\% para as classes de declividade. Desse modo, somente os tipos de solo com área superior a $5 \%$ da sub-bacia foram combinados para formar HRU, o mesmo valendo para a cobertura do solo e declividade.

Após a definição das HRU, o SWAT gera automaticamente um relatório com o número de HRU combinadas e a extensão das áreas referentes a cada tipo de solo, aos tipos de cobertura do solo e as classes de declividade, sendo apresentados os percentuais de cada um destes temas para cada sub-bacia. 


\subsubsection{Simulações}

Depois de carregados todos os planos de informação espacial e parâmetros de entrada, bem como definidas as HRUs para a bacia, pode-se iniciar o processo de simulação do SWAT propriamente dito.

O período definido para a simulação foi de 1/1/1992 até 12/31/2011, representando um total de 20 anos contínuos. Desses 20 anos, quatro foram utilizados para aquecimento do modelo, em procedimento conhecido como warm up, visto que, no início da simulação, ocorrem grandes incertezas devido ao desconhecimento das condições iniciais, principalmente em parâmetros como a umidade do solo (DURÃES, 2010).

A etapa posterior após a modelagem envolveria a calibração e a validação dos resultados obtidos pelo simulador. A calibração é um processo que requer séries históricas anuais de dados referentes a cada um dos componentes simulados, onde as entradas do modelo são modificadas até que um ajuste aceitável, que se aproxime dos valores observados, seja obtido. Geralmente os componentes são calibrados na seguinte ordem: parâmetros hidrológicos (frequentemente utiliza-se a vazão do canal), transporte de sedimentos e, por último, os parâmetros de qualidade da água.

Em vista da necessidade de séries históricas de vazão e de sedimentos, neste trabalho não foram realizadas as etapas de calibração e validação dos resultados obtidos. Apesar de terem sido encontrados na bacia registros de alguns postos fluviométricos, não seria viável sua utilização para calibração, devido ao pequeno período de monitoramento dos dados. Além disso, tais séries correspondem a períodos monitorados nas décadas de 70 e 80, não sendo compatíveis com o período simulado neste trabalho. Em relação aos sedimentos, não foram encontrados registros de nenhum posto hidrossedimentométrico na bacia. 


\subsection{Monitoramento de variáveis nos cursos d'água da bacia}

Objetivando reunir informações sobre a dinâmica dos sedimentos na bacia, foram realizadas medições de variáveis limnológicas em dez seções de amostragem, abrangendo desde trechos próximos das nascentes até as afluências ao reservatório (Figura 4). Nestas seções também foram medidas as respectivas vazões, bem como foi coletado o sedimento de fundo para análise granulométrica.

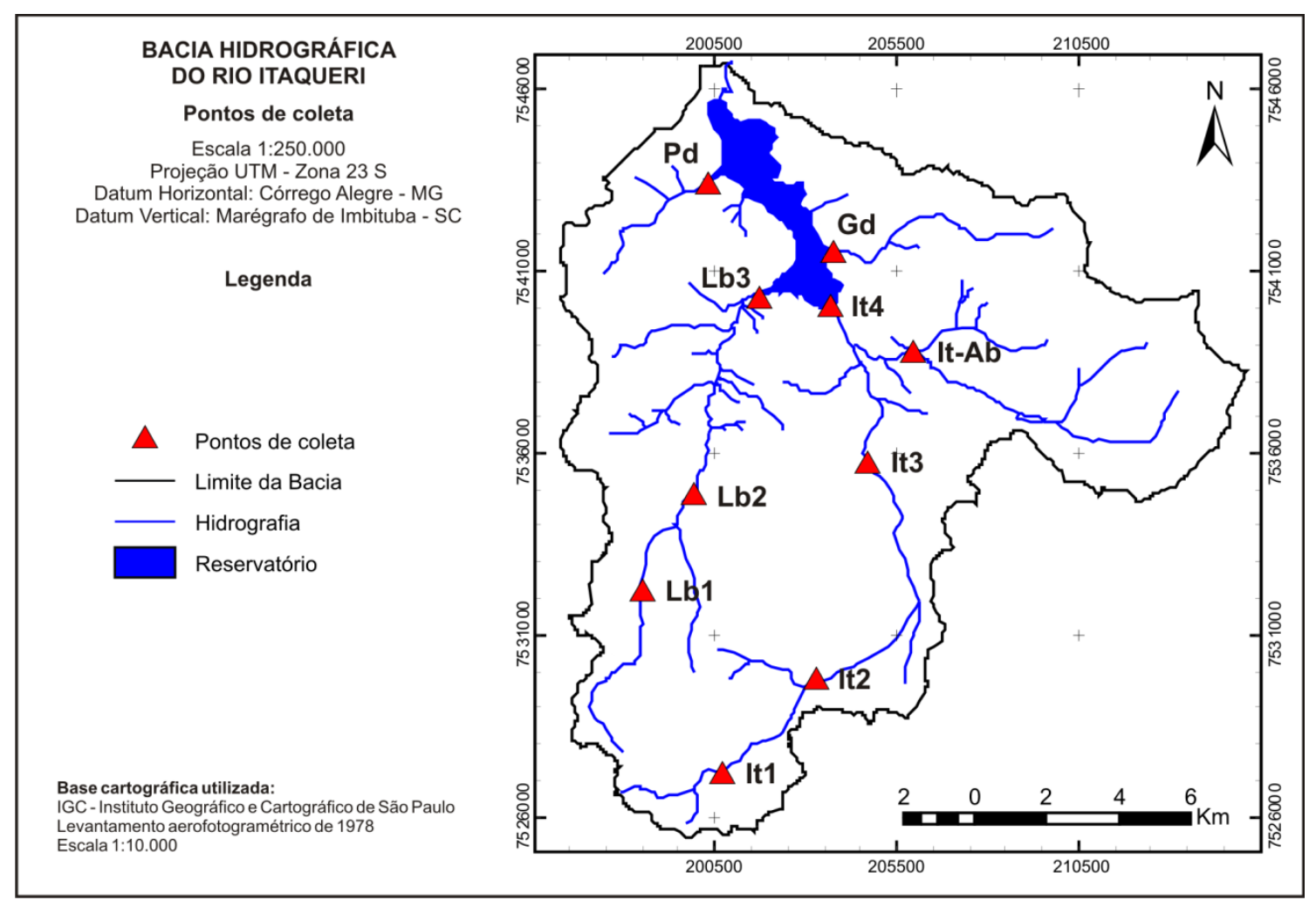

Figura 4 - Localização dos pontos de coleta de água e de sedimento nos tributários do reservatório

Foram amostrados cinco pontos no Rio Itaqueri (It1, It2, It3, It4 e It-Ab, sendo este último localizado no Córrego Água Branca, um de seus afluentes), três pontos no Ribeirão do Lobo (Lb1, Lb2 e Lb3), um ponto no Córrego do Geraldo (Gd) e um ponto no Córrego das Perdizes (Pd). Uma breve descrição destes locais amostrados é apresentada no Quadro 4. As coletas foram realizadas nos meses de março, junho, agosto e novembro de 2012, englobando desta forma os períodos seco e chuvoso. 
Quadro 4 - Caracterização das estações de amostragem nos afluentes do reservatório do Lobo

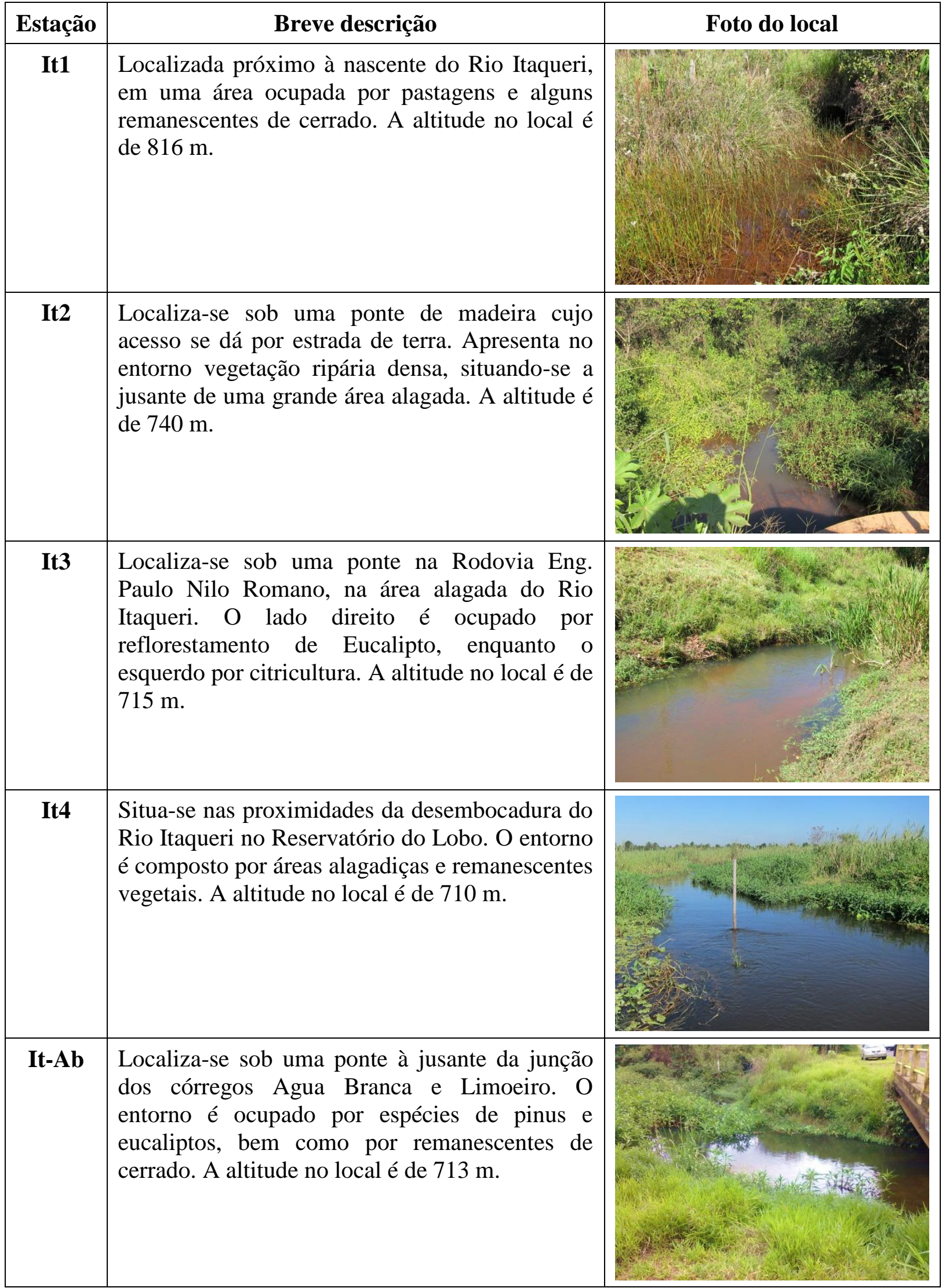




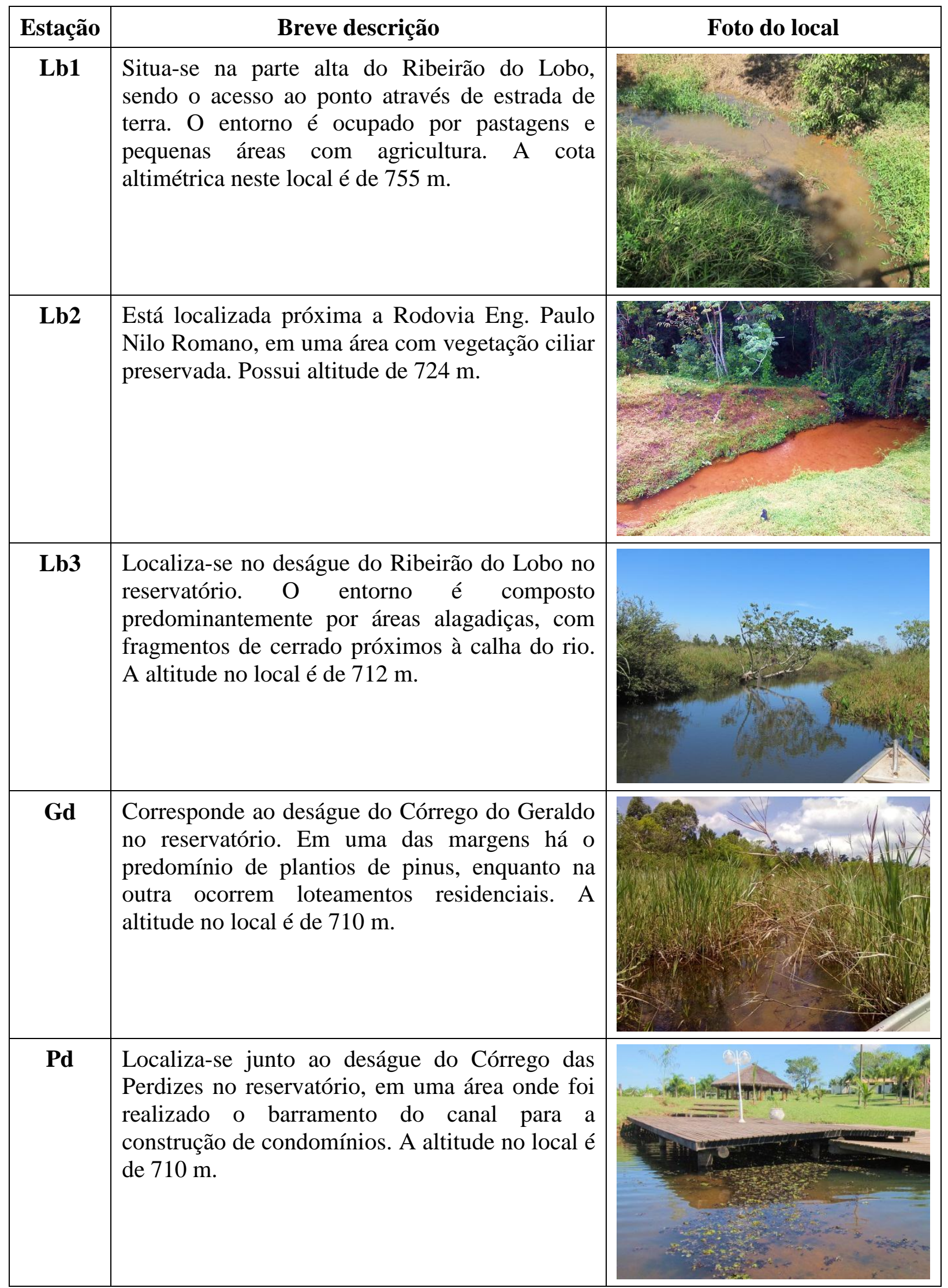


As variáveis limnológicas determinadas são apresentadas na Tabela 6, juntamente com uma breve descrição do método utilizado para sua obtenção. As variáveis obtidas em laboratório foram determinadas em duplicata, considerando-se ao final o valor médio entre os valores obtidos.

Tabela 6 - Variáveis limnológicas amostradas e métodos de determinação

\begin{tabular}{lc}
\hline \multicolumn{1}{c}{ Variáveis } & Método de determinação \\
\hline $\mathrm{pH}$ & Eletrométrico \\
Temperatura $\left({ }^{\circ} \mathrm{C}\right)$ & Eletrométrico \\
Condutividade elétrica $\left(\mu \mathrm{S} . \mathrm{cm}^{-1}\right)$ & Eletrométrico \\
Oxigênio dissolvido $\left(\mathrm{mg} . \mathrm{L}^{-1}\right)$ & Eletrométrico \\
Turbidez $(\mathrm{NTU})$ & Turbidimetria \\
Sólidos em suspensão, fixos e voláteis $\left(\mathrm{mg} \cdot \mathrm{L}^{-1}\right)$ & Gravimetria (APHA, 1995) \\
\hline
\end{tabular}

A determinação das variáveis $\mathrm{pH}$, temperatura, condutividade elétrica e oxigênio dissolvido foi realizada in situ, através de uma sonda multiparâmetros YSI modelo 6820. A turbidez foi obtida através da medição em turbidímetro de bancada modelo T-1000.

Para a determinação dos sólidos suspensos realizou-se a coleta de amostras de água para posterior análise em laboratório. Tais amostras foram coletadas no momento das medições em campo, armazenadas em recipientes de polietileno e preservadas em caixas de isopor com gelo.

A série de sólidos em suspensão foi determinada por método gravimétrico, conforme APHA, 1995. Os sólidos suspensos totais foram determinados a partir da filtragem das amostras em filtros de fibra de vidro $(45 \mu \mathrm{m})$ e evaporação em estufa a $105^{\circ} \mathrm{C}$, seguida de pesagem em balança analítica de alta precisão.

$\mathrm{Na}$ determinação das porções fixas e voláteis, os materiais residuais no filtro foram levados para calcinação em mufla a $550^{\circ} \mathrm{C}$ durante 30 minutos. Após o resfriamento em dessecador, estes foram novamente pesados, permitindo-se obter a partir da diferença entre as pesagens a quantificação das parcelas fixas e voláteis.

$\mathrm{Na}$ etapa de análise dos dados de qualidade da água, utilizou-se uma análise de componentes principais (ACP) para inferir o inter-relacionamento das variáveis amostradas. Escolheu-se para análise dos dados o software Statistica 7.0. Na etapa de pré-processamento os dados foram refinados de modo a desconsiderar valores característicos de erros 
instrumentais e de medição. Foi realizada também a logaritimização dos dados de entrada, para linearizar as relações e reduzir o efeito de valores elevados.

A análise de componentes principais foi aplicada para evidenciar possíveis associações entre as estações de amostragem e/ou datas de coleta e os parâmetros físicos e químicos da água. Tal análise foi baseada na matriz de correlações entre as variáveis, sendo utilizada como dado de entrada uma matriz 40x6, representando os valores de 6 variáveis $(\mathrm{pH}$, temperatura, condutividade elétrica, oxigênio dissolvido, turbidez e sólidos em suspensão totais) em 40 coletas (10 amostragens em cada uma das 4 campanhas em campo).

\subsection{Medição da vazão e determinação da carga sólida em suspensão}

Foi também realizada em campo a determinação da vazão de cada uma das seções de amostragem, por meio da realização de uma batimetria do perfil e da determinação da velocidade. Para a determinação da área da seção transversal foram medidas as profundidades em vários pontos do perfil, anotando-se as respectivas distâncias da margem.

Foram determinadas as velocidades em várias verticais da seção com o auxílio de um molinete fluviométrico Newton, da marca Hidromec. De posse destes valores, foram realizadas integrações em $x$ e em $y$ com os valores das velocidades para, a partir da área, obter a vazão de cada uma das subseções. A vazão total das seções foi obtida a partir do somatório das vazões em cada subseção.

Partindo-se dos valores de sólidos em suspensão medidos e da vazão, calculou-se a carga sólida em suspensão em cada uma das seções. Esta corresponde à relação da concentração de material suspenso com a velocidade que o mesmo está sendo transportado no canal, sendo expressa a quantidade transportada em massa por unidade de tempo conforme a equação 30 .

$$
\mathrm{F}=86,4 \cdot \mathrm{Q} \cdot \mathrm{C}
$$

Onde:

$\mathrm{F}=$ fluxo de massa na seção $(\mathrm{kg} / \mathrm{dia})$;

$\mathrm{Q}=\operatorname{vazão}\left(\mathrm{m}^{3} / \mathrm{s}\right)$;

C = concentração de sólidos em suspensão (mg/l); 
É importante ressaltar que as técnicas hidrossedimentológicas recomendam que durante a determinação da carga em suspensão as amostragens de sólidos suspensos devem ser realizadas em diversas verticais da seção estudada, pois a quantidade de material transportado em suspensão varia ao longo da seção em decorrência da variação de velocidade do fluxo. Entretanto, neste trabalho foram utilizadas amostragens pontuais de sólidos em suspensão para o cálculo da carga, visto que, devido ao pequeno porte dos cursos d'água da bacia, uma única amostragem pode representar com uma boa aproximação o transporte de sedimentos nas seções.

\subsection{Análise granulométrica do material do leito}

Durante as amostragens também foi coletado o sedimento de fundo utilizando-se um amostrador de material de leito (draga tipo Ekman). Tal material foi submetido à análise granulométrica para determinação do tamanho das partículas e suas respectivas porcentagens de ocorrência, sendo executados os procedimentos descritos conforme a norma técnica ABNT/NBR 7181/82.

Segundo tal metodologia, a distribuição granulométrica dos materiais granulares, areias e pedregulhos, é obtida através do processo de peneiramento das amostras de sedimento, enquanto que para siltes e argilas utiliza-se o processo de sedimentação em coluna. O ensaio por peneiramento consiste em agitar a amostra de sedimentos já seca em um conjunto de peneiras com aberturas sucessivamente menores, sendo que no caso deste experimento foram utilizadas as peneiras de número \#10 (2,000 mm), \#16 (1,180 mm), \#30 (0,600 mm), \#40 (0,425 mm), \#50 (0,300 mm), \#100 (0,150 mm) e \#200 (0,075 mm).

Já o ensaio de sedimentação baseia-se no princípio que as partículas do solo, quando dispersas na água, sedimentam-se com velocidades diferentes dependendo de sua forma, tamanho e viscosidade da água. Através da medição da densidade da coluna por meio de densímetro, foi possível calcular os diâmetros dessas partículas que compõem a amostra. 


\section{RESULTADOS E DISCUSSÃO}

Neste capítulo são apresentados e discutidos os resultados obtidos durante o desenvolvimento da pesquisa. A seção 6.1 é dedicada a uma breve caracterização do meio físico da bacia, onde são discutidas informações referentes à topografia, geologia, geomorfologia, pedologia, uso e ocupação do solo e sobre o clima. A seguir, na seção 6.2 são apresentados os resultados referentes à simulação hidrossedimentológica utilizando o SWAT, enquanto na seção 6.3 são discutidos os resultados obtidos através do monitoramento de qualidade da água. Na seção 6.4 são apresentados os dados referentes à vazão e ao cálculo da descarga sólida em suspensão, e, por fỉm, na seção 6.5 são discutidos os resultados da análise granulométrica do sedimento.

\subsection{Caracterização do meio físico da bacia do Rio Itaqueri}

\subsubsection{Relevo}

Na Figura 5 é apresentado o mapa hipsométrico da bacia hidrográfica do Rio Itaqueri, onde se verifica a presença de valores de altitude compreendidos entre 660 e 977 metros, representando um desnível altimétrico total de 317 metros. A altitude média da bacia é de 771 metros.

Verifica-se a predominância de maiores altitudes nos divisores ao sul da bacia, onde se situam as nascentes do Ribeirão do Lobo e do Rio Itaqueri, bem como nos divisores a leste, os quais representam o limite divisório entre a UGRHI 13 - Tietê/Jacaré e a UGRHI 5 Piracicaba/Capivari/Jundiaí. Na parte central da bacia há o predomínio de um relevo menos abrupto, sem elevações consideráveis, com os menores valores encontrados nas proximidades do reservatório, o qual está situado próximo à cota de 705 metros.

Já o mapa clinográfico da bacia é apresentado na Figura 6, onde os valores de declividade foram discriminados em cinco diferentes classes. 


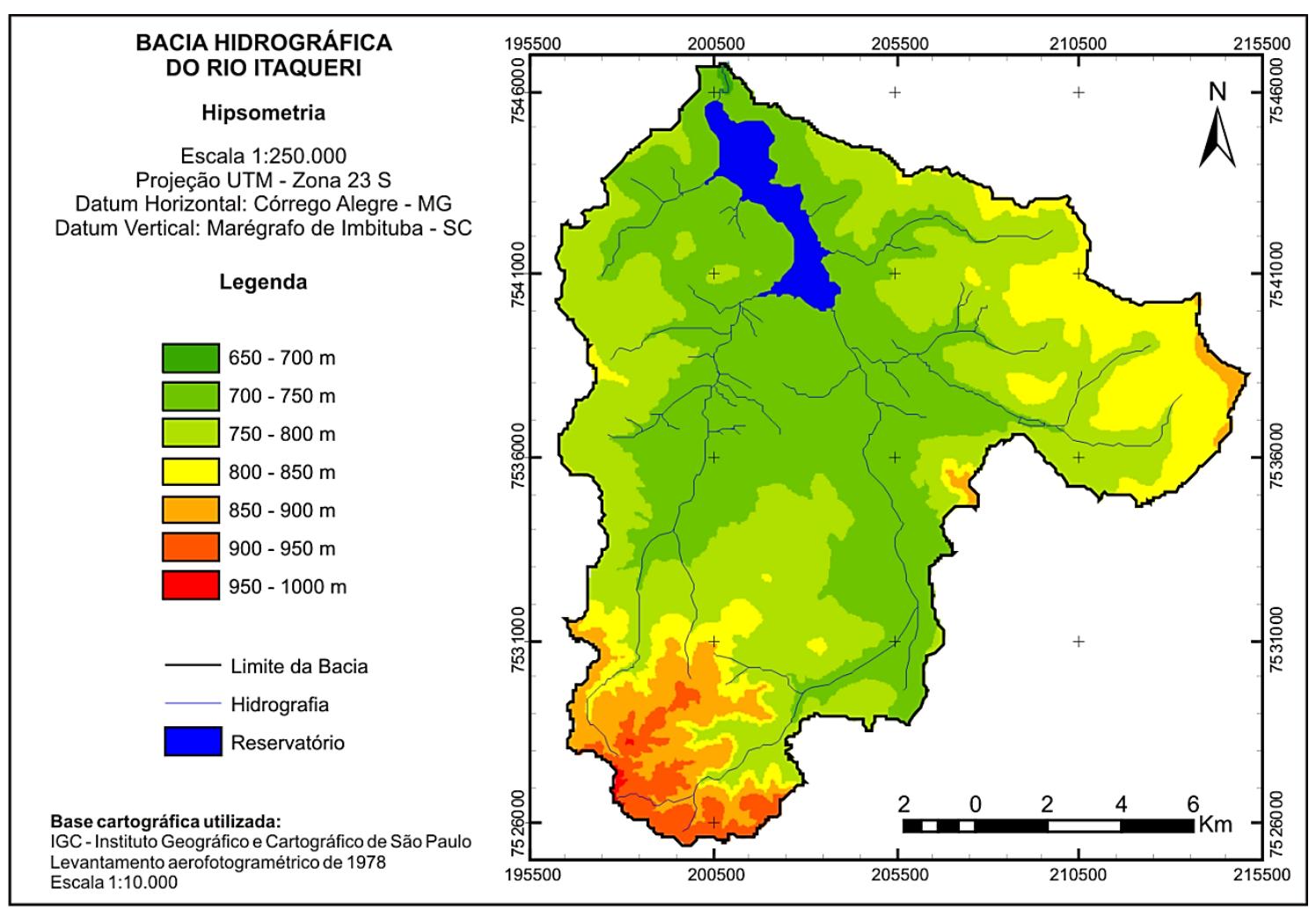

Figura 5 - Mapa hipsométrico da bacia do Rio Itaqueri

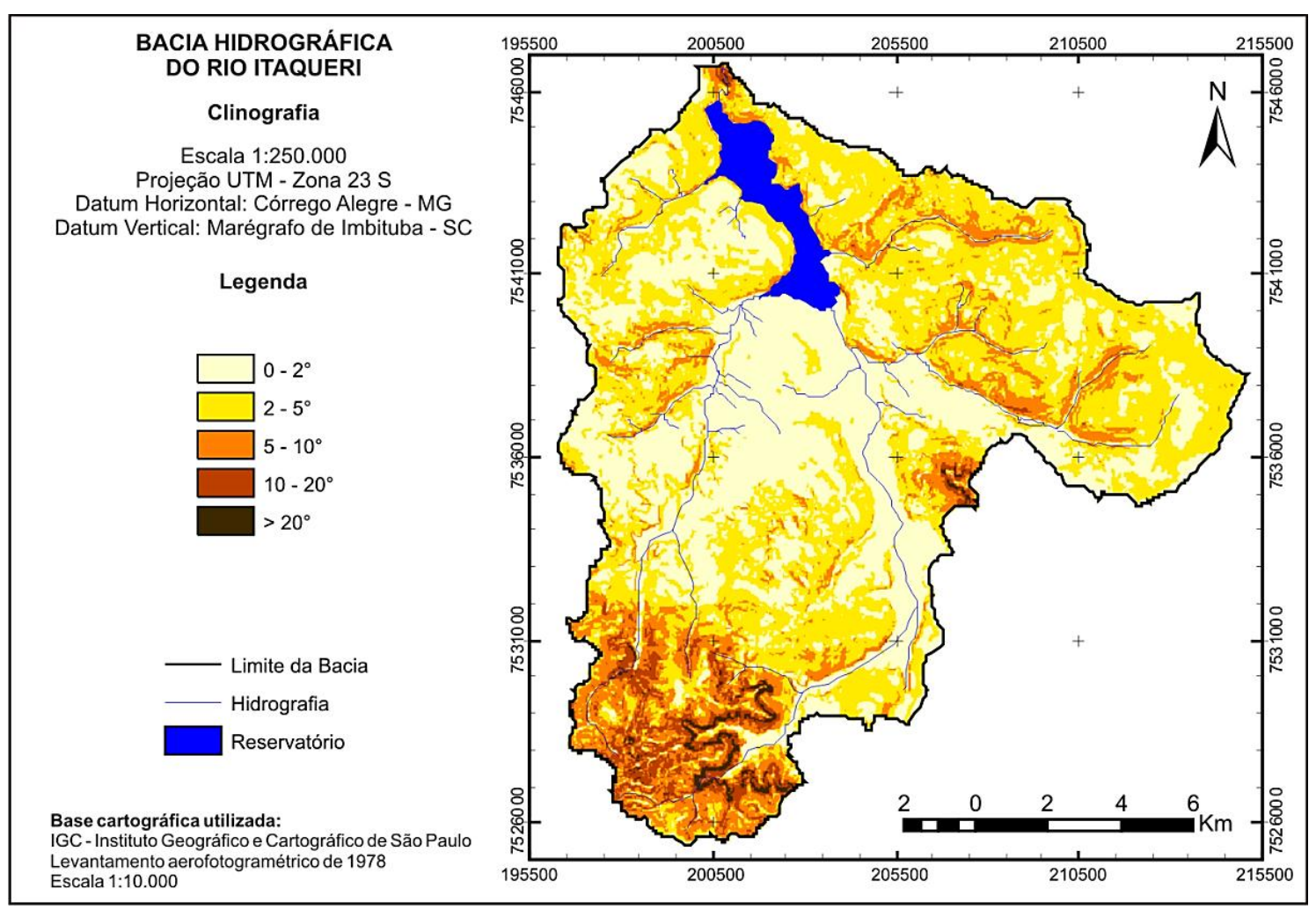

Figura 6 - Mapa das classes de declividade da bacia do Rio Itaqueri 
Verifica-se que grande parte da bacia apresenta valores de declividade inferiores a $2^{\circ}$ (40,1\% da área total), ocorrendo principalmente nas áreas próximas ao reservatório e junto às áreas inundáveis do Rio Itaqueri e Ribeirão do Lobo. Valores entre 2 e $5^{\circ}$ ocorreram em $41,5 \%$, enquanto valores entre 5 e $10^{\circ}$ ocorreram em 13,6\% da bacia, estes últimos encontrando-se principalmente nas vertentes próximas aos cursos d'água e na parte alta da bacia. As classes 10 a $20^{\circ}$ e acima de $20^{\circ}$ ocorreram em 3,9 e $0,9 \%$, respectivamente, localizando-se nas partes mais altas ao sul da bacia e nos trechos após o reservatório.

Através do ArcGIS 9.3 verificou-se que o valor máximo de declividade observado na bacia foi de $46,6^{\circ}$, enquanto o valor médio foi de $3,4^{\circ}$. Desse modo, conclui-se que na área de estudo há o predomínio de declividades baixas, sendo estas inferiores a $5^{\circ}$ em mais de $80 \%$ de seu território.

\subsubsection{Geologia}

No contexto regional, a área de estudo insere-se na província litoestrutural do Paraná, a qual consiste num pacote formado por sedimentos, em geral clásticos, e intrusões de derrames basálticos, abrangendo territórios no Brasil, Argentina, Paraguai e Uruguai. Tal província compreende três áreas de sedimentação independentes, separadas por profundas discordâncias ${ }^{1}$ : a Bacia do Paraná propriamente dita; a Bacia Serra Geral, compreendendo os arenitos eólicos da Formação Botucatu e os derrames basálticos da Formação Serra Geral; e a Bacia Bauru, uma bacia intracratônica (CPRM, 2003).

Em relação à geologia da bacia do Rio Itaqueri, verifica-se através da Figura 7 que afloram na área unidades litoestratigráficas pertencentes às Bacias Serra Geral e Paraná, cuja origem remete ao início do período Mesozóico, bem como sedimentos de origem mais recente pertencentes à Formação Itaqueri (período Cretáceo) e depósitos aluvionares/colúvioeluvionares, também de origem cretácea.

\footnotetext{
${ }^{1}$ Superfície que separa unidades estratigráficas de idades significativamente diferentes e que representa um grande período de não deposição ou de erosão das camadas abaixo e acima desta superfície de discordância.
} 


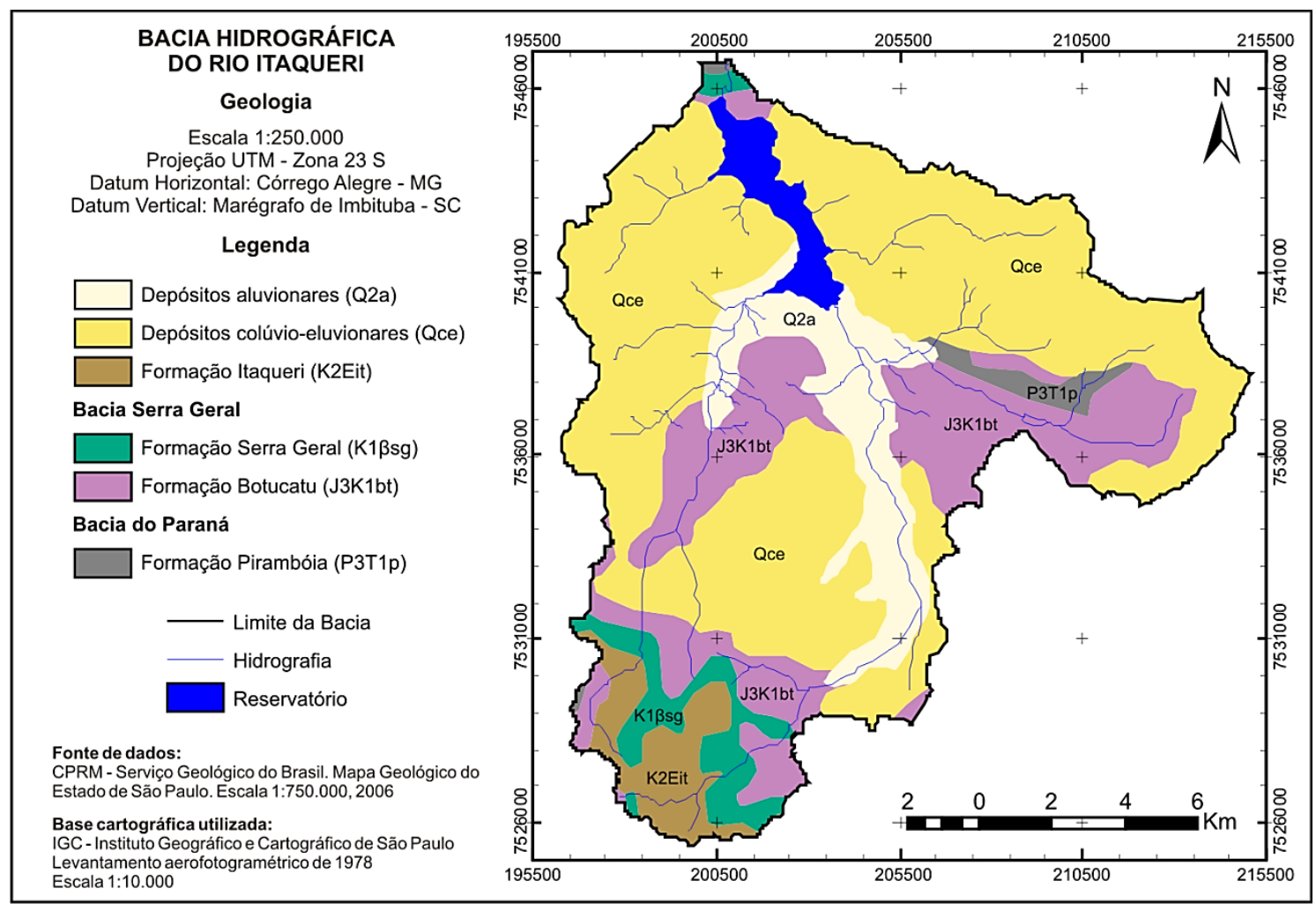

Figura 7 - Mapa geológico da bacia do Rio Itaqueri

A seguir são apresentadas as principais características das unidades litoestratigráficas encontradas na bacia, a partir de informações compiladas por IPT (2000) e CPRM (2003).

- Formação Serra Geral (K1ßsg): pertencente ao Grupo São Bento da Bacia Serra Geral, tal formação ocorre em uma pequena faixa na parte mais alta ao sul da bacia, representando 4,6\% de sua área total. É constituída por rochas vulcânicas toleíticas dispostas em derrames basálticos, com coloração cinza a negra, textura afanítica ${ }^{1}$, com intercalações de arenitos intertrapeanos finos a médios, apresentando estratificação cruzada tangencial.

- Formação Botucatu (J3K1bt): também pertencente ao Grupo São Bento da Bacia Serra Geral, tal formação ocorre em $21,6 \%$ da bacia. É formada predominantemente por arenitos eólicos avermelhados de granulação fina a média, com estratificações cruzadas de médio a grande porte. Ocorrem restritamente depósitos fluviais de natureza areno-conglomerática e camadas localizadas de siltitos e argilitos lacustres.

\footnotetext{
${ }^{1}$ Designação dada à textura que pode ser encontrada em rochas ígneas e que consiste numa massa constituída por cristais de pequena dimensão e sem forma definida, que testemunham que a rocha em questão arrefeceu rapidamente, não permitindo que os cristais atingissem maior dimensão nem uma forma regular.
} 
Segundo Krebs (2000), as rochas desta formação, juntamente com outras unidades gonduânicas, constituem o Aquífero Guarani, considerado um dos maiores aquíferos do mundo.

- Formação Pirambóia (P3T1p): aflora em uma pequena parte da bacia (1,6\%), nas proximidades do perímetro urbano de Itirapina. De origem mesozóica, é composta por depósitos de arenitos finos a médios, avermelhados, síltico-argilosos, com estratificação cruzada ou plano-paralela, apresentando ainda níveis de folhelhos e arenitos argilosos variegados e raras intercalações de natureza areno-argilosa.

- Formação Itaqueri (K2Eit): ocorre na parte alta da bacia, em uma faixa que representa $4,8 \%$ de sua área total. Considerada de origem mais recente quando comparada às formações anteriores (período Cretáceo), a Formação Itaqueri constitui-se de camadas alternadas de arenitos com cimento argiloso, folhelhos e conglomerados, estes situados tanto na base quanto no interior do pacote. Os arenitos são de granulação variada, podendo ser argilosos e apresentar intensa silicificação, com clastos provenientes de fora da bacia de deposição.

- Depósitos colúvio-eluvionares (Qce): configura-se como o compartimento predominante na bacia, ocorrendo em 56,6\% do território. São depósitos recentes, de origem quaternária (Pleistoceno), constituídos por materiais detríticos localmente remobilizados, em geral compostos por areia, silte e argila. Apresentam ainda coloração avermelhada com linha de seixos na base.

- Depósitos aluvionares (Q2a): ocorrem em 10,6\% da área de estudo, associados principalmente à rede de drenagem. De origem quaternária, compreendem as acumulações de sedimentos provenientes de planícies de inundação, terraços e depósitos de calha da rede fluvial atual e subatual, sendo compostos predominantemente por areias finas a grossas, cascalhos, lentes de material siltoargiloso e turfa.

\subsubsection{Geomorfologia}

Segundo a subdivisão geomorfológica do Estado de São Paulo proposta pelo IPT (1981), a qual divide o estado em cinco grandes províncias geomorfológicas, a região da bacia do Rio Itaqueri está inserida na província das Cuestas Basálticas. Esta província caracteriza-se morfologicamente por apresentar um relevo escarpado nos limites com a Depressão 
Periférica, seguido de uma sucessão de grandes plataformas estruturais de relevo suavizado, inclinadas para o interior, em direção à calha do rio Paraná. Estas duas feições principais constituem a escarpa e o reverso das cuestas.

Na Figura 8 são apresentados os sistemas de relevo presentes na área de estudo segundo o IPT (1981). Verifica-se que há na bacia a predominância de relevos de degradação, sob a forma de colinas amplas e colinas médias, formados a partir da ação contínua dos processos de denudação sobre áreas planálticas. Além disso, verifica-se a presença de relevos de agradação, caracterizados pelas planícies aluviais.

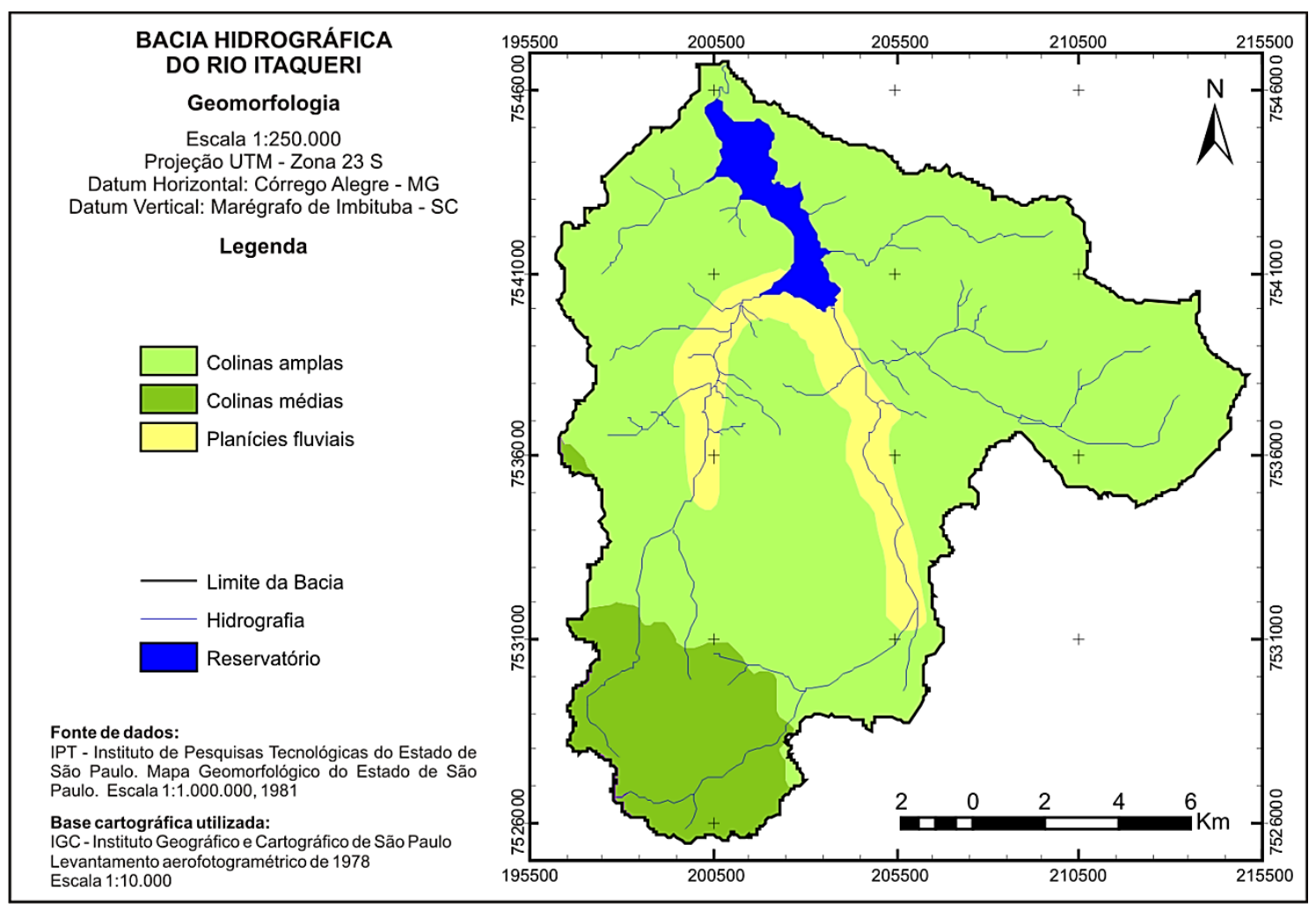

Figura 8 - Mapa geomorfológico da bacia do Rio Itaqueri

A seguir é apresentada uma breve caracterização destes sistemas de relevo encontrados na bacia.

- Colinas amplas: corresponde ao sistema de relevo predominante, ocorrendo em 78,3\% do território. Nestes locais predominam interflúvios com área superior a $4 \mathrm{~km}^{2}$, topos extensos e aplainados e vertentes com perfis retilíneos a convexos. Geralmente a drenagem é de baixa densidade e apresenta padrão subdendrítico. Os vales são abertos, com presença de planícies aluviais interiores restritas, podendo ocorrer eventualmente lagoas perenes ou intermitentes. 
- Colinas médias: ocupam $13,1 \%$ da área da bacia, ocorrendo na porção mais ao sul desta, onde há o predomínio de altitudes elevadas e afloramento das formações Itaqueri e Serra Geral. Neste tipo de relevo há o predomínio de interflúvios com áreas de 1 a $4 \mathrm{~km}^{2}$, topos aplainados e vertentes com perfis convexos a retilíneos. A drenagem é considerada de média a baixa densidade, apresentando padrão subretangular. Os vales são considerados de abertos a fechados, com a presença de planícies aluviais interiores restritas, podendo ocorrer ainda lagoas perenes ou intermitentes.

- Planícies aluviais: ocupam cerca de 8,5\% da área da bacia, ocorrendo nas proximidades do Rio Itaqueri e do Ribeirão do Lobo. Tal compartimento de relevo apresenta terrenos baixos e mais ou menos planos, junto às margens dos rios, sujeitos periodicamente a inundações.

\subsubsection{Pedologia}

Na Tabela 7 é apresentada a correspondência de nomenclaturas entre a antiga classificação e o atual Sistema Brasileiro de Classificação de Solos. As unidades do mapa original foram reclassificadas até o terceiro nível categórico, com exceção da classe Solos Orgânicos com ou sem Gley húmico, que, por falta de maior detalhamento no levantamento original, foi renomeada até o segundo nível categórico.

Tabela 7 - Correspondência entre a antiga classificação de solos e a atual

\begin{tabular}{ll}
\hline \multicolumn{1}{c}{ Nomenclatura antiga } & \multicolumn{1}{c}{ Nomenclatura do Atual SBCS } \\
\hline $\begin{array}{l}\text { Latossolo vermelho escuro álico, A moderado, textura } \\
\text { argilosa (LE-1) }\end{array}$ & Latossolo Vermelho Aluminoférrico (LVaf) \\
$\begin{array}{l}\text { Latossolo roxo distrófico, A moderado (LRd) } \\
\text { Latossolo vermelho amarelo álico, A moderado, } \\
\text { textura média (LV-2) }\end{array}$ & Latossolo Vermelho Distroférrico (LVdf) \\
$\begin{array}{l}\text { Podzólico vermelho amarelo distrófico, A moderado, } \\
\text { textura média ou média/argilosa (PV-4) }\end{array}$ & Argissolo Vermelho-Amarelo Distrófico (PVAd) \\
$\begin{array}{l}\text { Terra roxa estruturada eutrófica ou distrófica, A } \\
\text { moderado (TE-1) }\end{array}$ & Nitossolo Vermelho Eutroférrico (NVef) \\
$\begin{array}{l}\text { Areias quartzosas profundas, álicas, A moderado (AQ) } \\
\begin{array}{l}\text { Solos litólicos eutróficos, A moderado ou } \\
\text { chernozênico, textura argilosa (Li-3) }\end{array}\end{array}$ & Neossolo Quartzarênico Órtico (RQo) \\
\begin{tabular}{l} 
Solos orgânicos com ou sem Gley húmico (Or) \\
\hline
\end{tabular} & Neossolos Litólicos Eutróficos (RLe) \\
\hline
\end{tabular}


Na Figura 9 é apresentado o mapa de solos da bacia do Rio Itaqueri, elaborado tendo como base o levantamento pedológico realizado por Oliveira e Prado (1984) com as classes atualizadas. Verifica-se que ocorrem na área solos pedologicamente desenvolvidos, caracterizados por apresentarem horizontes superiores com alteração pronunciada dos minerais originais e desenvolvimento pedogenético bastante influenciado pelas condições climáticas da região, a exemplo dos Latossolos, Argissolos e Nitossolos. Entretanto, a maior parte da área da bacia é ocupada por solos pouco desenvolvidos, caracterizados por apresentar alteração incompleta dos minerais constituintes do substrato pedogenético, como os Organossolos e Neossolos.

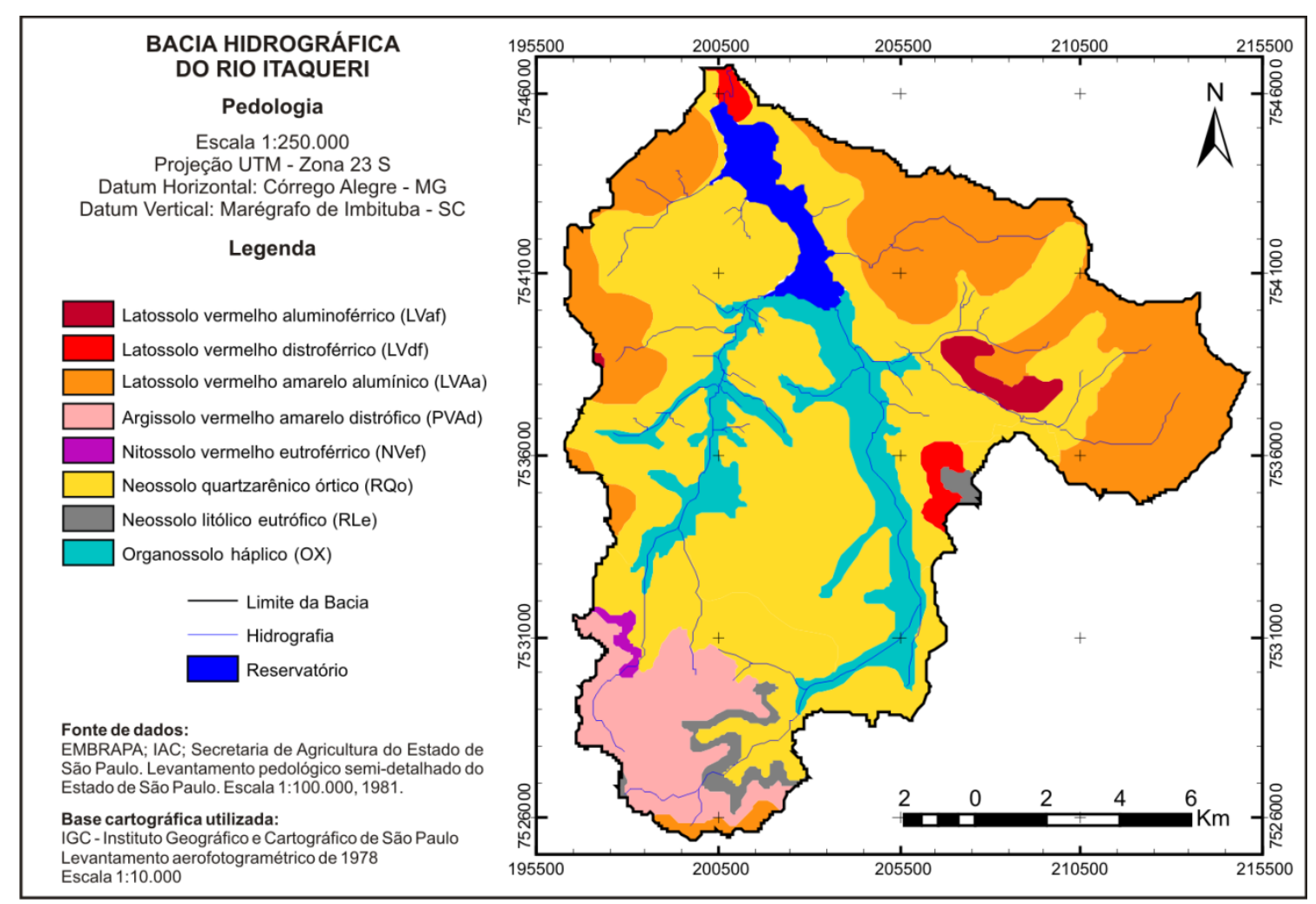

Figura 9 - Mapa de solos da bacia do Rio Itaqueri

A seguir é apresentada uma breve descrição dos compartimentos pedológicos ocorrentes na área de estudo, a partir de informações compiladas por Oliveira e Prado (1984) e IPT (2000).

- Latossolo Vermelho Distroférrico (LVdf): ocorrem na forma de manchas isoladas abrangendo cerca de 1,3\% da bacia. Correspondem a solos com horizonte B latossólico espesso e homogêneo, apresentando coloração avermelhada e alto teor de óxidos de ferro. Possuem horizonte A moderado, com textura argilosa ou muito 
argilosa, pouca areia grossa (inferior a 20\%), elevados teores de óxido de ferro $\left(\mathrm{Fe}_{2} \mathrm{O}_{3}\right.$ $>18 \%$ ) e saturação por bases baixa. São solos profundos, atingindo vários metros de espessura, e ocorrem em ambientes que favorecem a lixiviação de bases.

- Latossolo Vermelho Aluminoférrico (LVaf): correspondem a 1,5\% da área da bacia, ocorrendo na forma de manchas isoladas. Apresentam horizonte B latossólico espesso e homogêneo, com coloração avermelhada escura. São solos provenientes do intemperismo e retrabalhamento de sedimentos finos (argilitos e silitos), com variada contribuição de rochas básicas. Possuem horizonte A moderado, textura média a argilosa ao longo do perfil, com valor médio de alumínio trocável superior a $50 \%$ e saturação por bases baixa.

- Latossolo Vermelho Amarelo-Alumínico (LVAa): ocupando cerca de 25,6\% da área da bacia, tal compartimento pedológico distribui-se por extensas áreas de relevo pouco movimentado, constituído por colinas amplas, bem como nos topos aplainados de relevos mais movimentados. São solos com horizonte B latossólico espesso e homogêneo, apresentando coloração amarelo-avermelhada e caráter álico, com elevados índices de saturação em alumínio trocável (superiores a 50\%). O horizonte A é fraco ou moderado, enquanto o horizonte B apresenta teor de argila inferior a $20 \%$. Além disso, são solos considerados ácidos a muito ácidos, com saturação por bases baixa.

- Argissolo Vermelho-Amarelo Distrófico (PVAd): ocorrem em cerca de 8\% da bacia, situando-se em vertentes de maior declividade, estando associados ao relevo de colinas médias encontrado na porção sul da bacia. Compreendem solos minerais não hidromórficos, com horizonte $\mathrm{B}$ textural e apresentam individualização distinta de seus horizontes, decorrente das acentuadas diferenças em textura, cor e estrutura das camadas. São solos relativamente profundos, com cores desde vermelho até amarelo no horizonte B. Apresentam horizonte A moderado, de textura média, e horizonte B de textura média ou argilosa, com ausência de caráter abrupto, além de baixa saturação de bases em todo o perfil.

- Nitossolo Vermelho Eutroférrico (NVef): ocorrem em aproximadamente 0,4\% do território da bacia, estando associados a terrenos de altas declividades e relevos mais acidentados, como em áreas de cabeceiras de drenagem. São solos derivados de rochas básicas, os quais se caracterizam pela presença de horizonte B textural argiloso ou 
muito argiloso, com baixa relação textural, horizonte A moderado ou proeminente, elevada saturação de bases e alto teor de óxidos de ferro.

- Neossolo Quartzarênico Órtico (RQo): corresponde ao compartimento pedológico predominante na bacia, ocorrendo em 50,6\% do território. Esta classe compreende solos profundos, não hidromórficos, desenvolvidos sobre material de origem arenoso, onde o perfil é constituído por um horizonte A fraco ou moderado, raramente proeminente, assentado sobre um regolito inconsolidado. São solos arenosos, pedologicamente pouco desenvolvidos, constituídos essencialmente por minerais de quartzo e com estruturação muito frágil. Possuem ainda caráter álico e ausência de horizonte $\mathrm{B}$, tendo alta suscetibilidade à erosão.

- Neossolo Litólico Eutrófico (RLe): ocorrem em pequenas manchas espalhadas na bacia, perfazendo $1,8 \%$ de sua área total. Estes solos encontram-se associados e condicionados a relevos muito movimentados, em vertentes de alta declividade, ocorrendo, principalmente, associados às áreas de transição para relevos de colinas médias. Caracterizam-se por serem pouco desenvolvidos e apresentarem pequena espessura, normalmente com 20 a $40 \mathrm{~cm}$ de profundidade, devido à ausência de horizonte diagnóstico de subsuperfície. Apresentam horizonte A moderado ou chernozêmico e textura argilosa.

- Organossolo Háplico (OX): ocorrem em 10,8\% da bacia, situando-se nas áreas mal drenadas das planícies aluviais do Rio Itaqueri e do Ribeirão do Lobo. Possuem horizonte glei a menos de $80 \mathrm{~cm}$ de profundidade, com uma camada superficial de material orgânico igual ou superior a $40 \mathrm{~cm}$. Apresentam acentuada variação vertical e horizontal das características de hidromorfismo, decomposição da matéria orgânica e tipo de horizonte A, bem como uma diversidade textural bastante acentuada, o que dificulta sua caracterização em um nível categórico mais baixo.

\subsubsection{Uso e ocupação da terra}

Na Figura 10 é apresentado o mapa de uso e ocupação da terra gerado a partir da classificação supervisionada de uma imagem CBERS-2B datada de 2010, onde foram estabelecidas as seguintes classes: mata, campo/cerrado, pastagem, reflorestamento, cana-deaçúcar, citricultura, outras culturas, área urbanizada, área urbanizada de baixa densidade, solo exposto, área sujeita à inundação e água. 


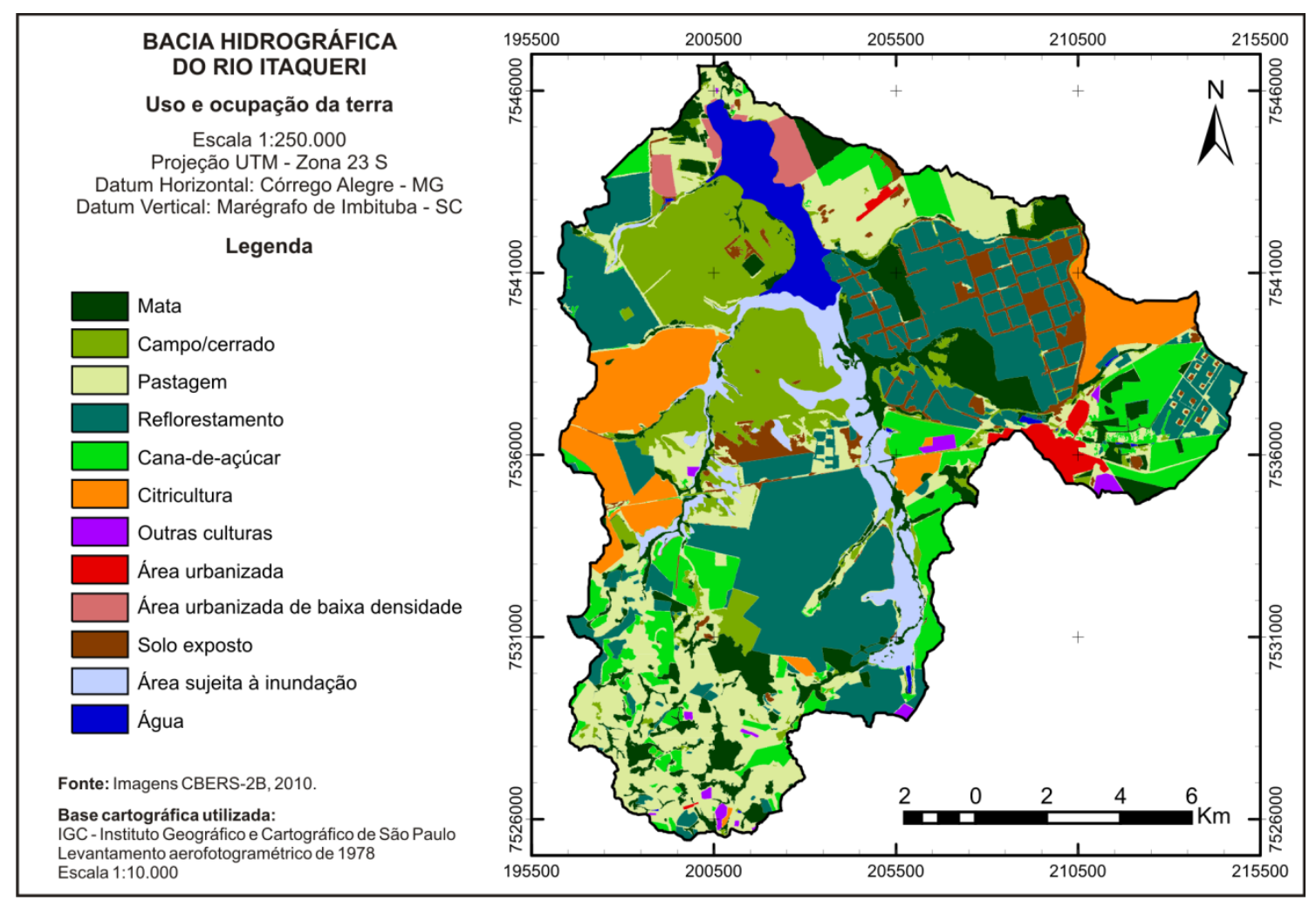

Figura 10 - Mapa de uso e ocupação da terra da bacia do Rio Itaqueri

Na Tabela 8 é apresentada a ocorrência das classes de uso e ocupação do solo, tanto em hectares quanto em porcentagem da área da bacia. Verifica-se que as áreas de mata correspondem a 11,2\% do território, sendo representadas principalmente por remanescentes florestais junto aos cursos d'água e por áreas protegidas (Áreas de Preservação Permanente e de Reserva Legal). Sob esta classe foram agrupadas superfícies de vegetação densa e de alto porte, como áreas de cerradão e fragmentos de Mata Atlântica.

As áreas classificadas como campo/cerrado correspondem a 13,5\% da bacia, ocorrendo em sua maior extensão nos limites da Estação Ecológica de Itirapina. Sob tal classe há o predomínio de vegetação com estrato arbóreo ausente, com ocorrência de plantas arbustivas e subarbustivas espaçadas entre si (subtipo denominado campo sujo).

A classe reflorestamento (pinus sp. e eucalyptus sp.) configura-se como o uso predominante na bacia, com 25,2\%, ocorrendo em extensas áreas com plantios homogêneos e de rápido crescimento. Boa parte do plantio de pinus sp. ocorre na Estação Experimental de Itirapina, a qual é destinada ao desenvolvimento de atividades silviculturais e visitação pública (DELGADO et al., 2004).

As áreas classificadas como pastagem perfazem 17,8\% da bacia, configurando-se como o segundo uso predominante. Estas correspondem a regiões de pecuária extensiva e 
regiões cobertas por gramíneas nas quais não há atividade pastoril, ocorrendo principalmente na parte alta da bacia e nas proximidades do reservatório.

Tabela 8 - Ocorrência das classes de uso e ocupação na bacia do Rio Itaqueri no ano de 2010

\begin{tabular}{lcc}
\hline Tipo de uso/ocupação & Ocorrência (ha) & Ocorrência (\%) \\
\hline Mata & 2480 & 11,2 \\
Campo/cerrado & 2986 & 13,5 \\
Pastagem & 3927 & 17,8 \\
Reflorestamento & 5583 & 25,2 \\
Cana-de-açúcar & 2099 & 9,5 \\
Citricultura & 1765 & 8,1 \\
Outras culturas & 126 & 0,6 \\
Área urbanizada & 248 & 1,1 \\
Área urbanizada de baixa densidade & 273 & 1,2 \\
Área sujeita à inundação & 1095 & 4,9 \\
Solo exposto & 921 & 4,1 \\
Água & 587 & 2,7 \\
\hline
\end{tabular}

As culturas agrícolas predominantes são a cana-de-açúcar e a citricultura, ocorrendo em $9,5 \%$ e $8,1 \%$ do total da bacia, respectivamente. Outras culturas como milho, arroz e café, ocorrem com menor representatividade, contabilizando $0,6 \%$ da área.

A classe área urbanizada ocorre em uma pequena parte da bacia $(1,1 \%)$, correspondendo ao perímetro urbano de Itirapina. Já a classe área urbanizada de baixa densidade diferencia-se desta última devido ao maior tamanho dos lotes, resultando em uma menor impermeabilização do solo, e devido à ausência de vias pavimentadas. Tais áreas ocorrem nas margens do reservatório do Broa, totalizando1,2\% da bacia, sendo constituídas principalmente por loteamentos residenciais e clubes recreativos.

Em relação às áreas de solo exposto, estas correspondem a 4,1\% da bacia, sendo caracterizadas principalmente por terrenos na fase de preparo para plantio, bem como por estradas de terra.

As áreas alagáveis ocuparam aproximadamente 4,9\% da bacia, ocorrendo principalmente junto às planícies do Rio Itaqueri e do Ribeirão do Lobo. Em sua maioria, estas correspondem a áreas onde há o predomínio de vegetação rasteira e de pequenos 
arbustos, estando periodicamente sujeitas à inundação. Por fim, a área classificada como água totalizou 2,7\% da bacia, correspondendo essencialmente ao reservatório do Broa.

\subsubsection{Aspectos climáticos}

O clima da área de estudo é, segundo a classificação climática de Köppen, do tipo Cwa, ou seja, mesotérmico com inverno seco, onde a temperatura média do mês mais frio é inferior a $18^{\circ} \mathrm{C}$, a do mês mais quente é superior a $22^{\circ} \mathrm{C}$ e o total das chuvas do mês mais seco não ultrapassa $30 \mathrm{~mm}$ (SILVA, 2005).

Na Figura 11 é apresentado o climograma da área de estudo, elaborado a partir de uma série histórica de 20 anos (1992 a 2011), cedida pela estação meteorológica instalada no Centro de Recursos Hídricos e Ecologia Aplicada (CRHEA), a qual localiza-se próxima ao exutório da bacia estudada.

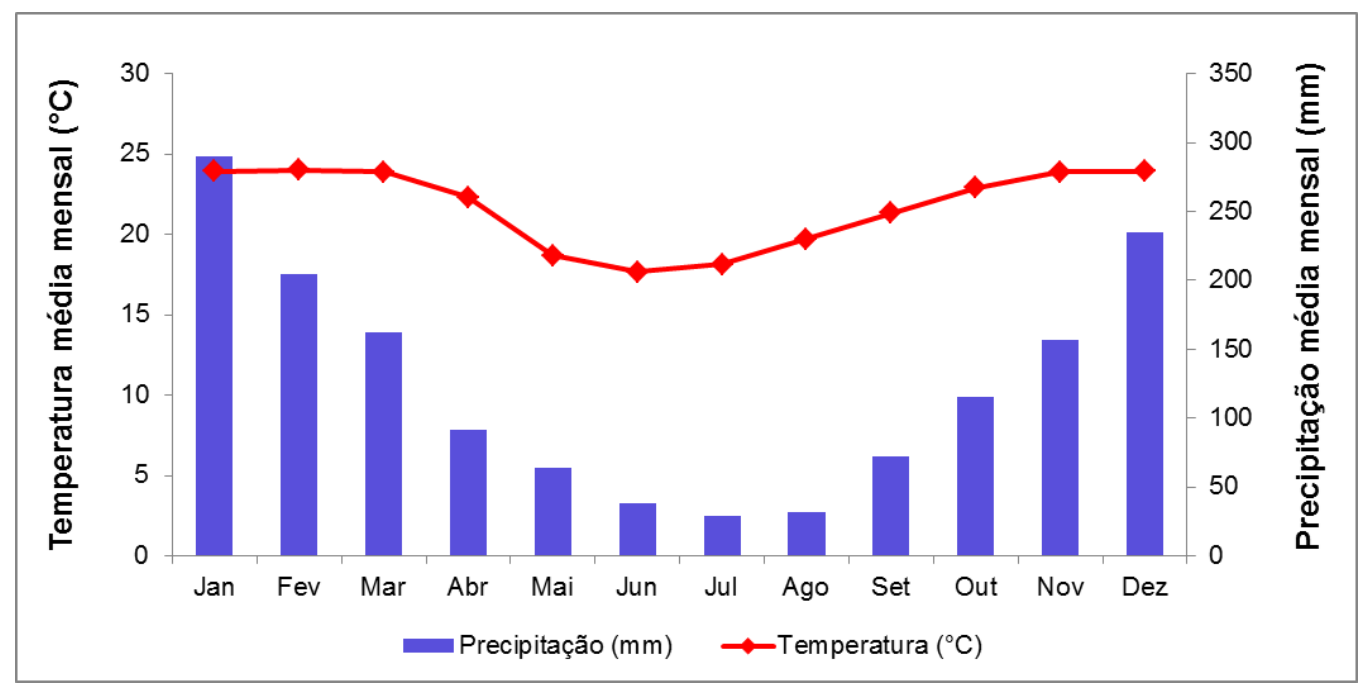

Figura 11 - Precipitação e temperatura média mensal no período de 1992 a 2011

Através da análise do climograma verifica-se a má distribuição das chuvas durante o ano, ocorrendo maior precipitação nos meses de outubro a março, e as menores temperaturas nos meses de abril a setembro. Desse modo, conclui-se que o clima da área de estudo é caracterizado pela presença de um período seco (inverno), sob influência predominante de sistemas polares, e um período chuvoso (verão), influenciado pelos sistemas tropicais (SILVA, 2005).

A precipitação média anual é de $1.515 \mathrm{~mm}$, com mais de $78 \%$ das chuvas ocorrendo na estação chuvosa (outubro a março) e os $22 \%$ restantes no período seco (abril a setembro). 
O mês mais chuvoso é janeiro, contabilizando uma média mensal de $289,5 \mathrm{~mm}$, enquanto o mês de menor precipitação é julho, com 28,9 mm.

Em relação à temperatura, a média anual é de $21,6^{\circ} \mathrm{C}$, onde o mês mais quente é fevereiro, com média mensal de $24,0^{\circ} \mathrm{C}$, e o mês mais frio é junho, com $17,6^{\circ} \mathrm{C}$. Na Figura 12 é apresentada a média das temperaturas máxima e mínima referentes a cada mês no período de 1992 a 2011. Verifica-se que o mês com maior temperatura máxima é fevereiro, com $29,6^{\circ} \mathrm{C}$, enquanto o mês com menor temperatura mínima é julho, com $9,3^{\circ} \mathrm{C}$.

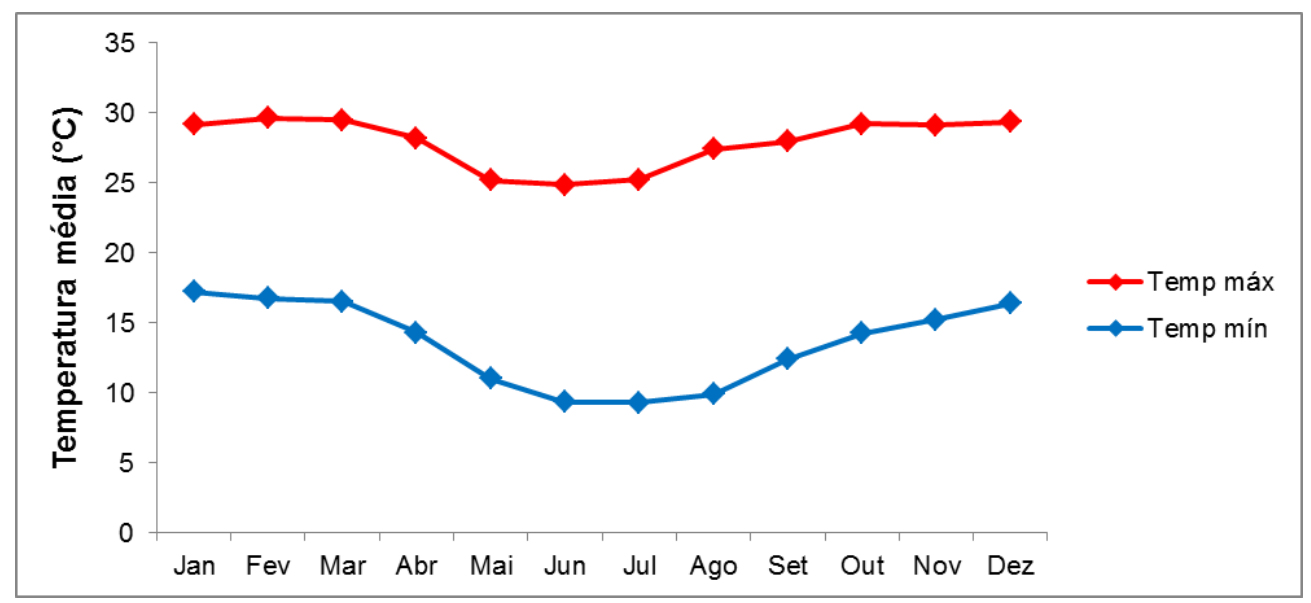

Figura 12 - Média das temperaturas máxima e mínima mensal no período de 1992 a 2011

A velocidade média anual do vento na área é de $1,18 \mathrm{~m} / \mathrm{s}$, tendo seus maiores valores nos meses de setembro a dezembro, variando em torno de 1,60 m/s. Segundo Calijuri (1988), a direção mais frequente é o vento sul, responsável por provocar a homogeneização das águas do reservatório.

A umidade relativa média anual da área gira em torno de $73,4 \%$, com os maiores valores ocorrendo nos meses de janeiro $(78,1 \%)$ e fevereiro $(78,2 \%)$, propiciando um verão quente e úmido, e os menores valores nos meses de agosto $(67,8 \%)$ e setembro $(69,9 \%)$, caracterizando o inverno frio e seco da região.

Os valores de radiação solar mostram sazonalidade semelhante à apresentada pelas médias de temperatura, tendo os maiores valores ocorrendo no verão e na primavera, com máximo de 19,13 MJ/m².dia no mês de novembro. Os menores valores de radiação foram observados em junho, com mínimo de $11,4 \mathrm{MJ} / \mathrm{m}^{2}$.dia, visto que nesta época o Sol encontrase no seu ponto mais extremo em relação ao hemisfério sul. A média anual observada na estação para todo o período foi de $15,6 \mathrm{MJ} / \mathrm{m}^{2}$.dia. 


\subsection{Modelagem utilizando o SWAT}

No SWAT, os resultados das simulações são informados através de parâmetros referentes a cada sub-bacia definida anteriormente, onde o usuário pode escolher o passo de tempo a ser considerado na simulação, podendo este ser diário, mensal ou anual. Nesta seção, são apresentados os resultados para a simulação, a qual foi realizada para o período de $1 / 1 / 1992$ a $31 / 12 / 2011$.

\subsubsection{Divisão em sub-bacias de contribuição}

$\mathrm{Na}$ etapa referente à modelagem hidrológica, a bacia do Rio Itaqueri foi dividida em 32 sub-bacias, apresentadas na Figura 13. No momento da escolha dos seus exutórios, procurou-se realizar uma distribuição que não apresentasse muita discrepância entre as áreas das sub-bacias, de forma que estas apresentassem a mesma ordem de grandeza. Além disso, procurou-se inserir os pontos de monitoramento da qualidade da água e de sedimento como exutórios de sub-bacias.

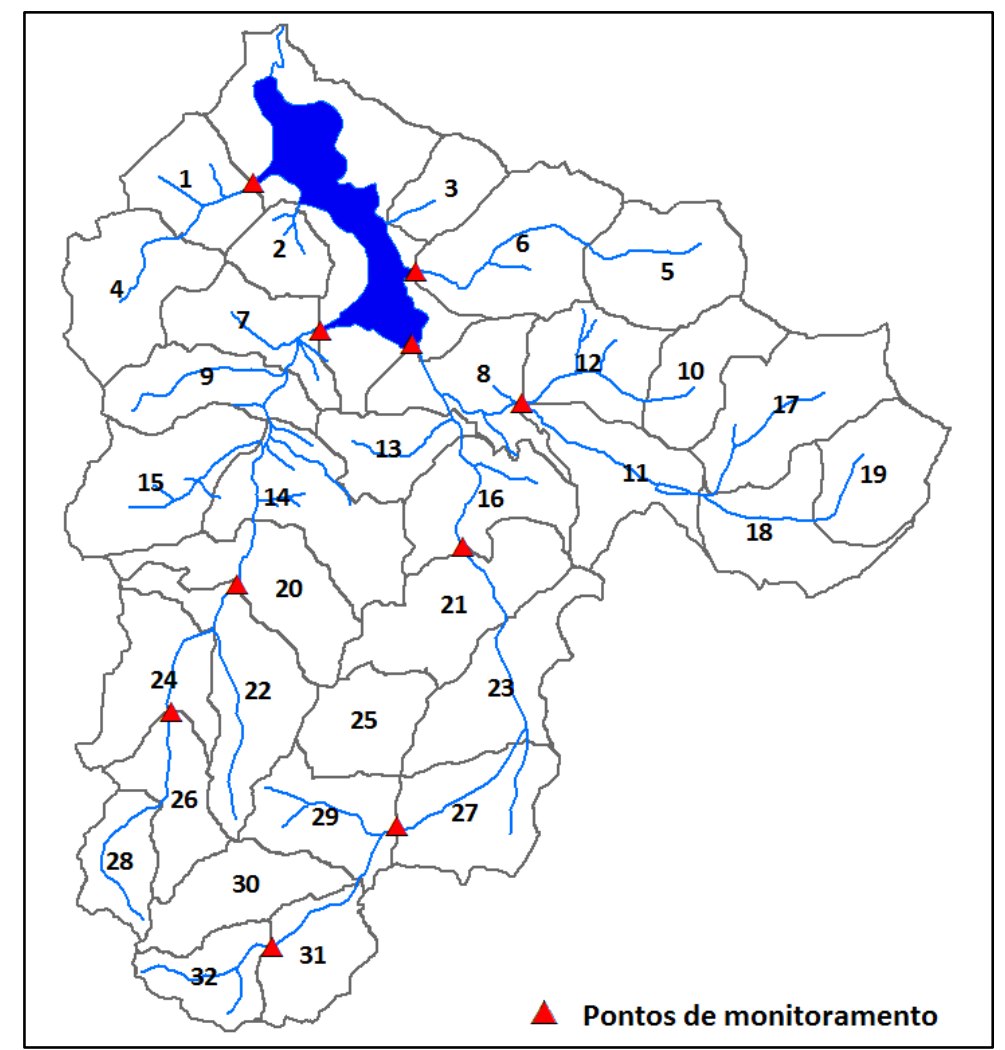

Figura 13 - Divisão da bacia do Rio Itaqueri em sub-bacias de contribuição 
Durante o processo de simulação foram criadas 668 HRU, indicando, portanto, 668 combinações de uso do solo, tipo de solo e classes de declividade distribuídas pelas 32 subbacias delimitadas. Através do relatório topográfico gerado pelo SWAT, verificou-se que a sub-bacia de menor área foi a de número 2, com 312,1 ha, enquanto a bacia de maior área foi a sub-bacia 6 , com 859,5 ha.

\subsubsection{Modelagem hidrológica}

$\mathrm{Na}$ Figura 14 são apresentados os valores simulados para a percolação, para o escoamento superficial e para a evapotranspiração em cada uma das 32 sub-bacias. Tais valores correspondem às médias anuais destes componentes no período entre 1992 e 2011.

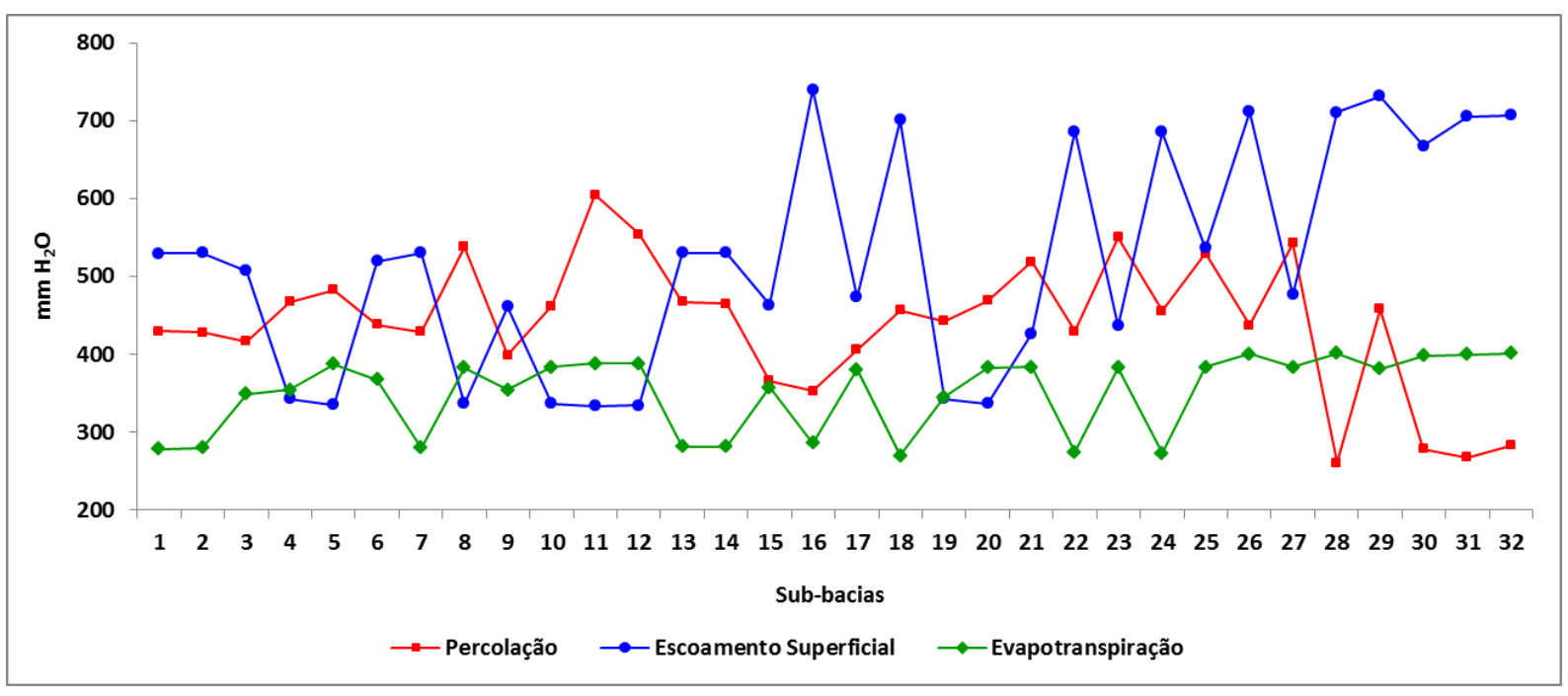

Figura 14 - Médias anuais de percolação, escoamento superficial e evapotranspiração para as 32 sub-bacias no período simulado

A precipitação média anual sobre as 32 sub-bacias durante o período foi de $1515 \mathrm{~mm}$, dos quais $521 \mathrm{~mm}$ correspondem à média anual de escoamento, $440 \mathrm{~mm}$ à média de percolação e 351 à média de evapotranspiração. A quantidade de água restante para fechamento do balanço corresponde à parcela de água presente no solo, à parcela de recarga do aquífero profundo e ao fluxo lateral.

Verifica-se que em 21 das 32 sub-bacias o escoamento superficial é maior do que a percolação, enquanto em 11 delas há o predomínio da percolação. Estas últimas estão localizadas, em sua maioria, em áreas de declividade menos acentuada, o que permite que a água infiltre com maior facilidade. 
Já nas sub-bacias localizadas na parte alta da bacia (sub-bacias 28 a 32) os valores de percolação são bastante baixos, enquanto os de escoamento superficial são elevados. Tal configuração pode ser melhor visualizada na Figura 15, onde é apresentado o mapa da média anual de escoamento superficial por sub-bacia durante o período de 1992 a 2011.

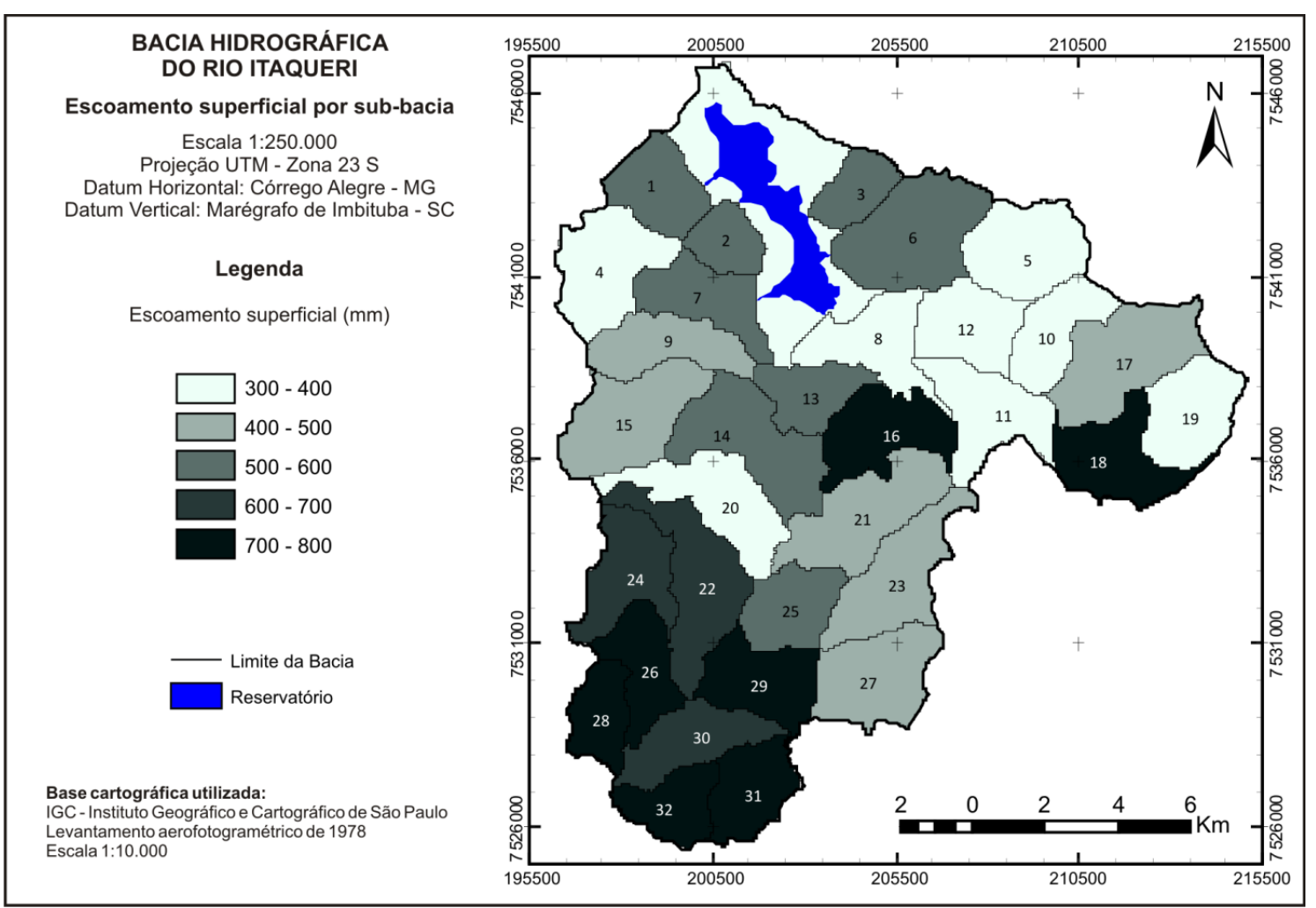

Figura 15 - Mapa de escoamento superficial para cada sub-bacia

Através da Figura 15 verifica-se que as áreas mais elevadas ao sul da bacia produziram valores de escoamento superficial superiores a $600 \mathrm{~mm}$, com o valor máximo de 735,7 mm na sub-bacia de número 29. Por estarem situadas em áreas de elevada declividade, estas bacias produzem escoamento de maneira mais rápida durante a precipitação, ocasionando um maior volume escoado. Além disso, nestas áreas se desenvolvem solos com taxas de infiltração baixas e muito baixas, a exemplo dos Argissolos e Neossolos Litólicos (pertencentes aos grupos hidrológicos C e D, respectivamente), contribuindo para gerar valores elevados de escoamento.

As sub-bacias de menor produção de escoamento correspondem, em grande parte, a áreas de menor declividade em que ocorrem solos com maior taxa de infiltração, como os Latossolos Vermelhos e Latossolos Vermelho-Amarelos (grupos hidrológicos A e B, respectivamente). Além disso, as sub-bacias que apresentaram porcentagens significativas de 
áreas de mata produziram valores de escoamento considerados baixos, visto que a cobertura vegetal tende a retardar o escoamento e facilitar a infiltração.

\subsubsection{Produção de sedimentos}

Na Figura 16 são apresentados os resultados da produção média anual de sedimentos por sub-bacia para o período de 1992 a 2011, os quais foram especializados de modo a permitir uma melhor avaliação de sua distribuição espacial.

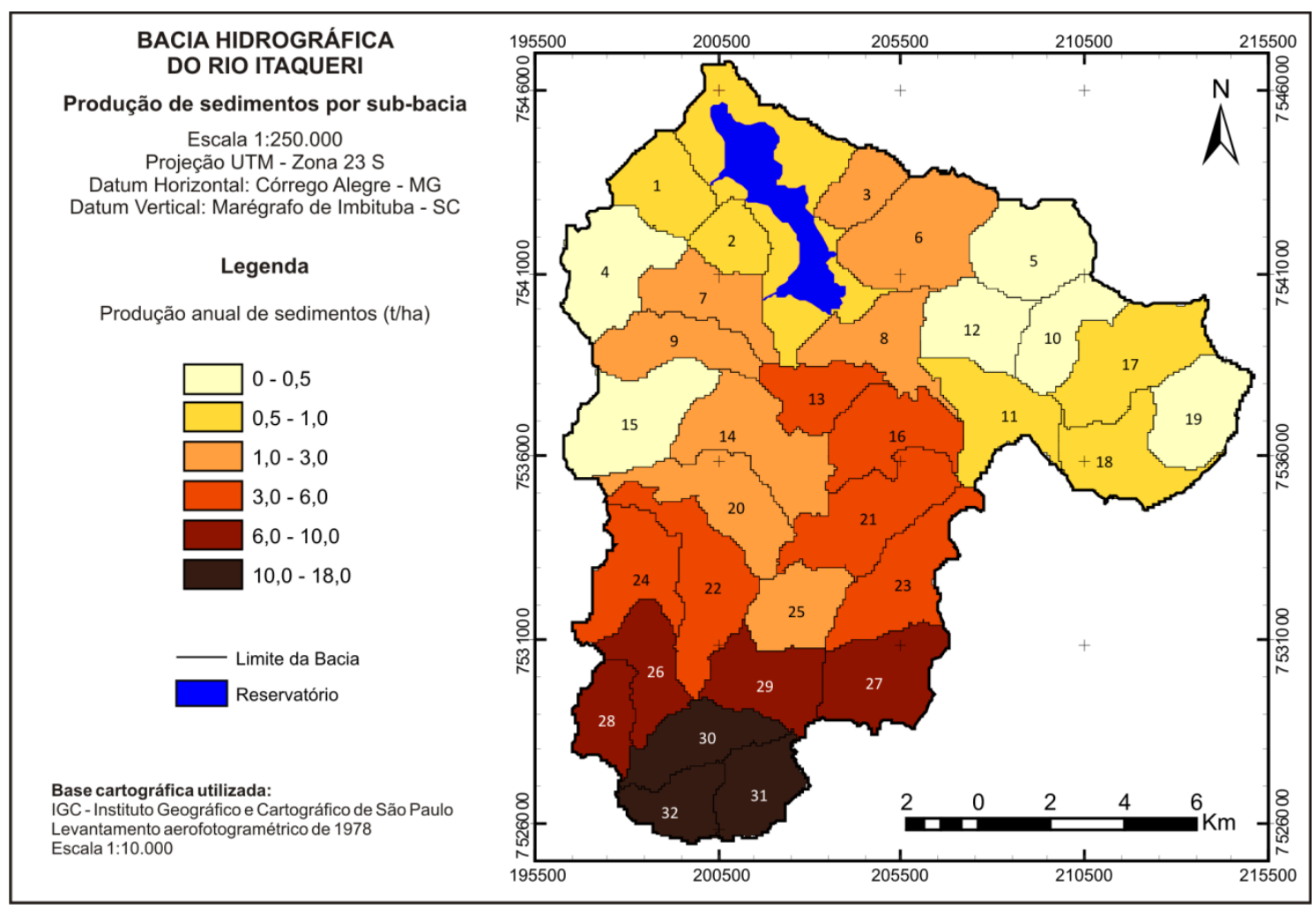

Figura 16 - Mapa da produção de sedimentos para cada sub-bacia

Verifica-se que a produção de sedimentos na bacia do Rio Itaqueri apresentou desde valores próximos a zero em algumas áreas até valores próximos a 18 t/ha. De modo geral, a distribuição espacial da produção de sedimentos mostrou-se bastante dispersa, sendo que poucas áreas são responsáveis pelo valores mais elevados de sedimentos que chegam aos cursos d'água. Em relação ao valor médio de produção de sedimentos para toda a bacia, este foi de 3,52 t/ha.

As áreas de maior produção de sedimentos ocorrem ao sul da bacia, nas proximidades das nascentes do Ribeirão do Lobo e do Rio Itaqueri, seguindo a tendência observada na 
produção de escoamento superficial. Como a simulação da produção de sedimentos é realizada em função das relações hídricas de precipitação e escoamento, é esperado que os maiores valores ocorram em áreas onde o escoamento é elevado, visto que nessas condições os materiais desagregados serão mais facilmente transportados até o canal.

Nestas áreas, além de serem encontradas declividades acentuadas, observam-se apenas alguns fragmentos de vegetação nativa protegendo os maiores declives, estando o restante do território ocupado por pastagens e plantios de cana-de açúcar. Tais características, aliadas às aos solos de erodibilidade moderada e forte que ocorrem nestas áreas, acabam por gerar uma maior perda de solo, e, consequentemente, maior produção de sedimentos.

A título de comparação, nas Tabelas 9 e 10 são apresentadas as porcentagens das classes de tipo de solo, de cobertura do solo e de declividade de duas sub-bacias com diferentes potencias de geração de sedimento. Na Tabela 9 são descritas as classes referentes à sub-bacia de número 5, cuja área é de 730 ha e a produção de sedimentos é de 0,18 t/ha, uma das menores dentre as sub-bacias. Já na Tabela 10 estão os dados da sub-bacia 31, com uma área de 509 ha e uma produção de 17,32 t/ha, o maior valor dentre todas as sub-bacias.

Tabela 9 - Composição dos tipos de solo, cobertura e classes de declividade da sub-bacia 5

\begin{tabular}{lclclc}
\hline Tipo de solo & Área (\%) & Uso do solo & Área (\%) & Declividade & Área (\%) \\
\hline LVAa & $66,7 \%$ & Reflorestamento & $60,9 \%$ & 2 a $5 \%$ & $41,0 \%$ \\
RQo & $33,3 \%$ & Mata & $17,8 \%$ & 5 a $10 \%$ & $38,1 \%$ \\
& & Pastagem & $15,4 \%$ & 10 a $25 \%$ & $10,6 \%$ \\
& & Outros & $5,9 \%$ & Outros & $10,3 \%$ \\
\hline
\end{tabular}

Tabela 10 - Composição dos tipos de solo, cobertura e classes de declividade da sub-bacia 31

\begin{tabular}{lclccc}
\hline Tipo de solo & Área $(\%)$ & Uso do solo & Área $(\%)$ & Declividade & Área $(\%)$ \\
\hline RQo & $36,7 \%$ & Pastagem & $55,4 \%$ & 10 a $25 \%$ & $41,9 \%$ \\
RLe & $25,4 \%$ & Mata & $21,1 \%$ & 5 a $10 \%$ & $21,8 \%$ \\
PVAd & $24,2 \%$ & Cana & $14,4 \%$ & $>25 \%$ & $18,4 \%$ \\
Outros & $13,7 \%$ & Outros & $9,1 \%$ & Outros & $17,9 \%$ \\
\hline
\end{tabular}

Em relação aos tipos de solo, dois terços da sub-bacia 5 são compostos por Latossolos Vermelho-Amarelos, considerados de baixa erodibilidade, enquanto um terço é composto por Neossolos Quartzarênicos, que possuem erodibilidade alta. Já a sub-bacia 31 é composta em 
sua maioria por Neossolos Quartzarênicos e Neossolos Litólicos, além de uma parcela de Argissolos Avermelho-Amarelos, todos considerados como solos de alta erodibilidade.

$\mathrm{Na}$ sub-bacia 5 uma boa parte da área (mais de 75\%) é coberta por reflorestamento de pinus e por mata nativa, ocorrendo apenas uma pequena parcela de pastagens em $15 \%$ do território. Já na sub-bacia de maior produção de sedimentos, o uso predominante do solo são as pastagens, com a ocorrência de plantios de cana-de-açúcar.

Por fim, na sub-bacia 5 há o predomínio de declividades inferiores a $10 \%$ em mais de $80 \%$ da área, enquanto na sub-bacia 31 as declividades inferiores a $10 \%$ ocorrem em menos de $40 \%$ da superfície. Mais de $18 \%$ da sub-bacia apresenta declividades superiores a $25 \%$, o que, no processo de modelagem, resulta em maiores valores do fator LS da MUSLE, elevando significativamente a perda de solo.

Desse modo, verifica-se que relevos acidentados associados a solos erodíveis e coberturas que oferecem pouca proteção são condicionantes que levam a maiores perdas de solo, e consequentemente, maiores produções de sedimento. Porém, é preciso destacar que a conexão entre a geração, o transporte e a produção de sedimentos é bastante complexa, envolvendo, além dos atributos discutidos acima, fatores como a intensidade das chuvas, a deposição de materiais em depressões da bacia, a agradação e degradação dentro do canal e a capacidade de rede de drenagem em transportar sedimentos.

A partir dos resultados obtidos para a produção de sedimentos nas sub-bacias em toneladas por hectare, estimou-se também a quantidade total de sedimento produzida na bacia do Rio Itaqueri, bem como as quantidades produzidas pelas bacias de cada um dos afluentes do Reservatório do Broa. Na Tabela 11 são apresentados os resultados desta estimativa.

Verifica-se que a quantidade anual total de sedimento produzida na bacia foi de 77.905 toneladas. Deste total, 50.866 toneladas chegam ao reservatório através do Rio Itaqueri, o que corresponde a $65,2 \%$ da produção total de sedimentos da bacia. Pelo Ribeirão do Lobo, entram no reservatório 19.551 toneladas, o que corresponde a $25 \%$ da produção total. Os Córregos das Perdizes e do Geraldo apresentaram produções menos expressivas, contabilizando 600 e 1.861 toneladas de sedimento por ano, o que corresponde a $0,7 \%$ e 2,3\% do total, respectivamente.

Sob a categoria 'outros' foram contabilizadas as produções de afluentes de menor importância e a produção referente à sub-bacia em que se encontra o reservatório, incluindo neste montante os sedimentos que chegam diretamente à represa por escoamento superficial e subsuperficial, não sendo carregados por nenhum curso d'água. Nesta categoria, a produção de sedimentos foi de 5.025 toneladas, o que corresponde a $6,4 \%$ da produção total da bacia. 
Tabela 11 - Quantidade total anual média de sedimentos produzida nas bacias dos principais contribuintes do Reservatório do Broa

\begin{tabular}{lcc}
\hline \multicolumn{1}{c}{ Afluente } & Sedimento produzido $(\mathbf{t})$ & Área drenada (ha) \\
\hline Rio Itaqueri & 50.866 & 10.562 \\
Ribeirão do Lobo & 19.551 & 5.930 \\
Córrego das Perdizes & 600 & 1.274 \\
Córrego do Geraldo & 1.861 & 1.690 \\
Outros & 5.025 & 2.620 \\
TOTAL & 77.905 & 22.076 \\
\hline
\end{tabular}

A título de comparação, Uzeika (2009) aplicou o modelo SWAT em uma pequena bacia hidrográfica rural, no Rio Grande do Sul, cuja extensão é de 119 ha. Na área, caracterizada pela ampla presença de lavouras, restando poucas áreas com vegetação nativa, a autora obteve um total de 701,1 toneladas de sedimento produzidas por ano, com uma produção média para a bacia de 5,89 t/ha.

Paim (2012) utilizou o modelo na Bacia do Rio Piçarras (8.925 ha), em Santa Catarina, a qual situa-se próxima ao litoral, sendo composta por serras tabulares e planícies litorâneas. Apesar de possui uma porcentagem expressiva de mata na bacia, a média de produção de sedimento foi de 52,9 t/ha, sendo 472.675,8 toneladas a quantidade total de sedimento produzida. Em ambas as pesquisas, verifica-se que as médias de produção de sedimento apresentaram-se superiores à média obtida neste trabalho.

Na Tabela 11 ainda são apresentadas as áreas das bacias de contribuição de cada um dos afluentes. De modo geral, nota-se que as maiores produções de sedimento ocorreram nos tributários que drenam maiores áreas, evidenciando a relação direta entre a produção de sedimento e o tamanho da bacia de drenagem.

\subsection{Monitoramento de parâmetros de qualidade da água}

Nesta seção serão apresentados os dados referentes à qualidade da água nos cursos d'água da bacia do Rio Itaqueri. Tais dados foram obtidos durante quatro campanhas de coleta realizadas nos meses de março, junho, agosto e novembro de 2012.

$\mathrm{Na}$ Figura 17 são apresentados os valores obtidos para o $\mathrm{pH}$, onde verifica-se que estes estão compreendidos no intervalo entre 4,5 e 6,8, indicando que as águas de todos os afluentes são ácidas ou ligeiramente ácidas. Tal tendência ácida observada está relacionada à natureza 
dos solos da bacia, que, condicionados pela presença de vegetação de cerrado, apresentam elevados teores de alumínio e baixos teores de matéria orgânica, sendo caracterizados como solos bastante ácidos.

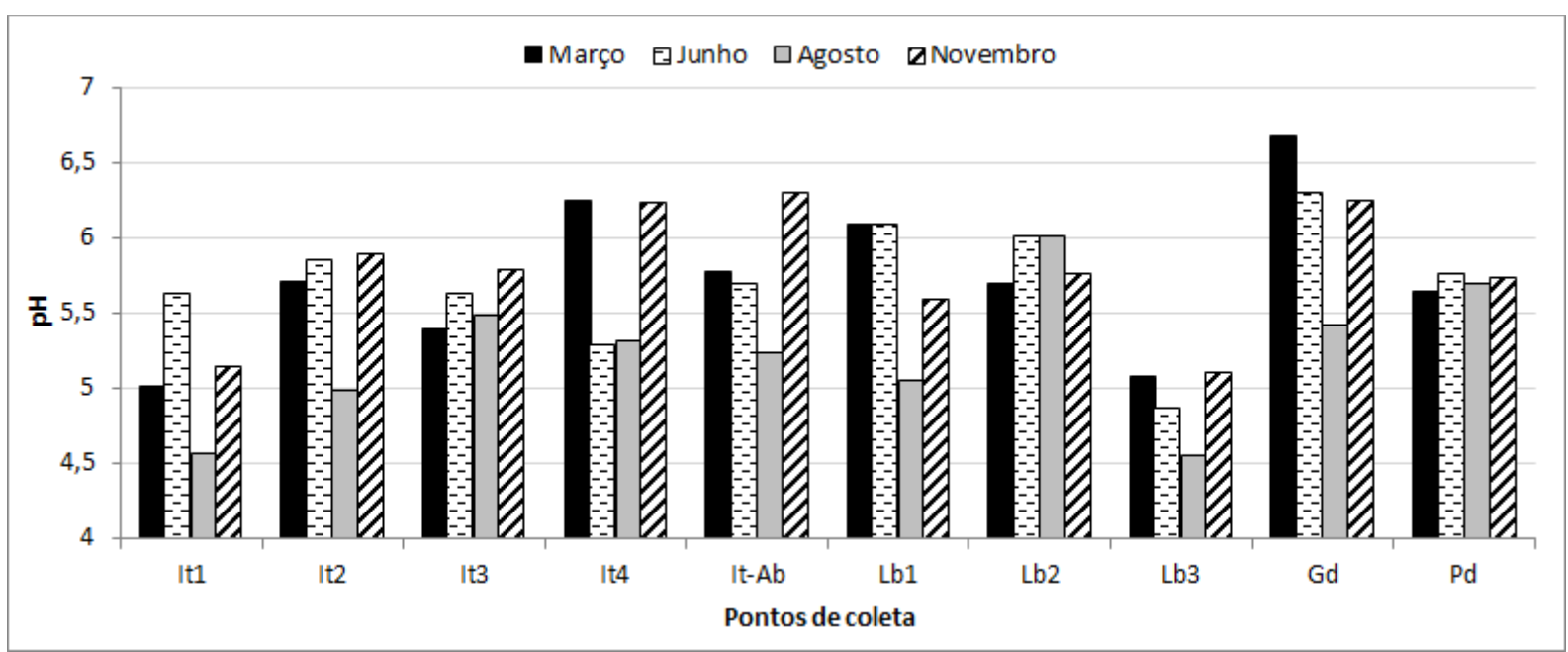

Figura 17 - Variação espacial do pH nos afluentes do Reservatório do Lobo nos meses de março, junho, agosto e novembro de 2012

Em todas as coletas, os menores valores de $\mathrm{pH}$ foram observados na desembocadura do Ribeirão do Lobo (ponto Lb3), tendo o mínimo de 4,6 no mês de agosto. Segundo Reid e Wood (1976) apud Matheus e Tundisi (1988), rios que drenam pântanos e brejos possuem normalmente $\mathrm{pH}$ bastante ácido devido a presença de ácidos húmicos decorrentes do processo de decomposição de matéria orgânica autóctone, o que explica os baixos valores neste ponto.

Baixos valores de $\mathrm{pH}$ também foram observados na nascente do Rio Itaqueri (Ponto It1), apresentando um aumento nas estações seguintes. Além disso, é possível verificar que em quase todas as estações os menores valores de $\mathrm{pH}$ ocorreram na coleta de agosto, enquanto nos meses mais chuvosos tais valores foram um pouco mais elevados.

Vários trabalhos realizados anteriormente verificaram a acidez das águas na região, sendo obtidos valores de $\mathrm{pH}$ sempre inferiores a 7, a exemplo de Matheus e Tundisi (1988), Oliveira (1993) e Argenton (2004).

Em relação ao oxigênio dissolvido (Figura 18), verifica-se que os menores valores dentre as estações de coleta foram obtidos no médio curso do Rio Itaqueri (It2), tendo o mínimo de 2,1 mg/l em março. Especula-se que o decréscimo do oxigênio neste ponto esteja relacionado ao lançamento de efluentes de criações de animais provenientes das propriedades 
rurais a montante. Nota-se ainda que ocorre um aumento do OD nas duas estações a jusante deste ponto, o que indica a ocorrência de depuração natural do curso d'água.

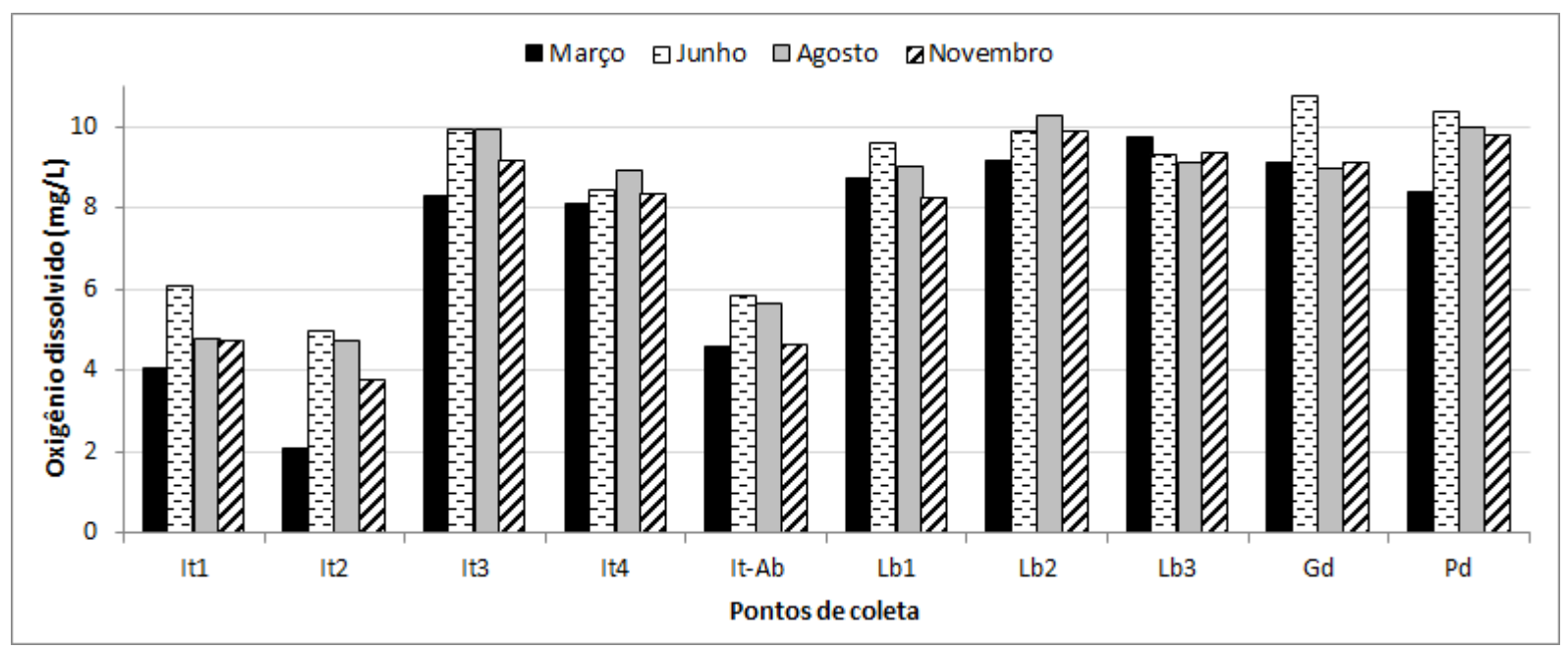

Figura 18 - Variação espacial do oxigênio dissolvido nos afluentes do Reservatório do Lobo nos meses de março, junho, agosto e novembro de 2012

Também foram obtidos baixos valores de OD no Córrego da Água Branca (4,6 mg/l em março e 4,7 mg/l em novembro). Tais valores podem ser influenciados pelos efluentes lançados pela estação de tratamento de esgotos de Itirapina, localizada cerca de $2 \mathrm{~km} \mathrm{a}$ montante do ponto de amostragem. Os valores obtidos nesta estação, bem como nas estações It1 e It2, mostraram-se inferiores aos $5 \mathrm{mg} / \mathrm{l}$ estabelecidos pela Resolução CONAMA 357/2005 para corpos d'água classe 2. Já nas estações de coleta do Ribeirão do Lobo e dos Córregos das Perdizes e Geraldo foram observados valores elevados de OD em todas as coletas (acima de 8,0 mg/l).

Observou-se também que os valores de OD nos meses mais quentes foram menores do que nos meses mais frios em praticamente todas as estações amostradas. Isto decorre do fato de que a solubilidade do oxigênio em água depende da temperatura e da pressão atmosférica, visto que em temperaturas maiores ocorre uma menor solubilização de gases na massa líquida (ESTEVES, 1998).

Em relação ao parâmetro temperatura, apresentado na Figura 19, verifica-se que não ocorrem diferenciações significativas entre os pontos de amostragem, sendo as pequenas variações encontradas atribuídas ao sombreamento ocasionado pela vegetação marginal presente em alguns pontos. O ponto de coleta $\mathrm{Pd}$, no Córrego das Perdizes, apresentou os maiores valores em todas as coletas, tendo o máximo de $26,3^{\circ} \mathrm{C}$ em novembro. Os maiores 
valores neste ponto são explicados pela ausência de vegetação ciliar no trecho e pelo fato de haver diversos represamentos a montante.

Sazonalmente, os valores de temperatura acompanharam o padrão climático da região, com os maiores valores ocorrendo nas coletas de março e novembro, e os menores nos meses mais frios.

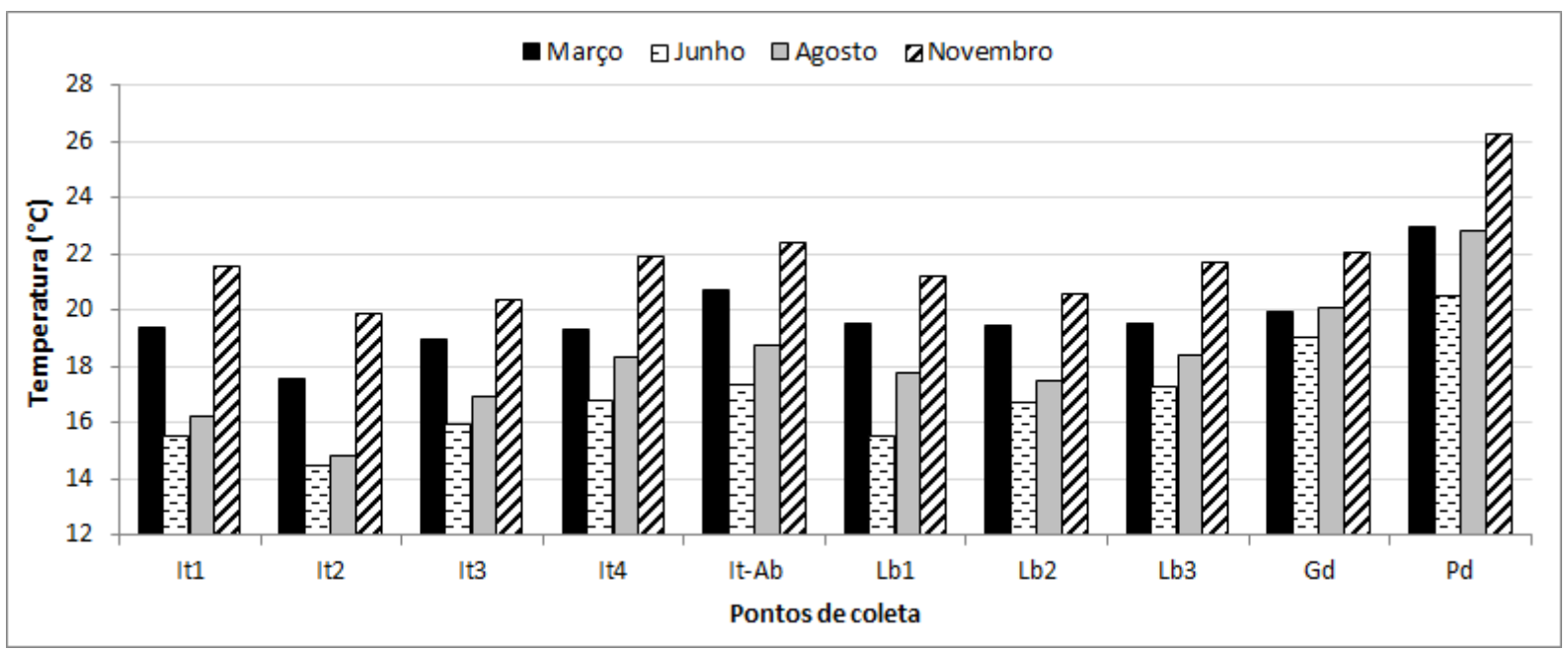

Figura 19 - Variação espacial da temperatura nos afluentes do Reservatório do Lobo nos meses de março, junho, agosto e novembro de 2012

Na Figura 20 são apresentados os dados relativos à condutividade elétrica, onde se verifica que os maiores valores ocorreram nas nascentes dos Rios Itaqueri (It1) e Lobo (Lb1) durante a coleta de agosto, sendo de $87 \mu \mathrm{s} / \mathrm{cm}$ e $79 \mu \mathrm{s} / \mathrm{cm}$, respectivamente. Outro ponto onde os valores de CE foram elevados foi no Córrego da Água Branca (It-Ab), com valores entre $35 \mu \mathrm{s} / \mathrm{cm}$ e $80 \mu \mathrm{s} / \mathrm{cm}$ durante o período analisado.

Segundo a CETESB, valores de condutividade acima de $100 \mu \mathrm{s} / \mathrm{cm}$ são indicativos de ambientes impactados, sendo que valores muito altos caracterizam águas com alto poder corrosivo. Apesar de tal limite não ter sido superado em nenhuma das coletas, supõe-se que os maiores valores encontrados nas nascentes do Itaqueri e do Lobo podem estar relacionados ao desenvolvimento de atividades pecuárias na parte alta da bacia. Já os valores elevados encontrados no Córrego da Água Branca podem sofrer influência da estação de tratamento de esgotos de Itirapina, fato já observado em outros trabalhos (Matheus e Tundisi, 1988; Carvalho, 2011). Em relação aos demais pontos amostrados, os valores de condutividade não ultrapassaram $30 \mu \mathrm{s} / \mathrm{cm}$ na maioria das coletas. 


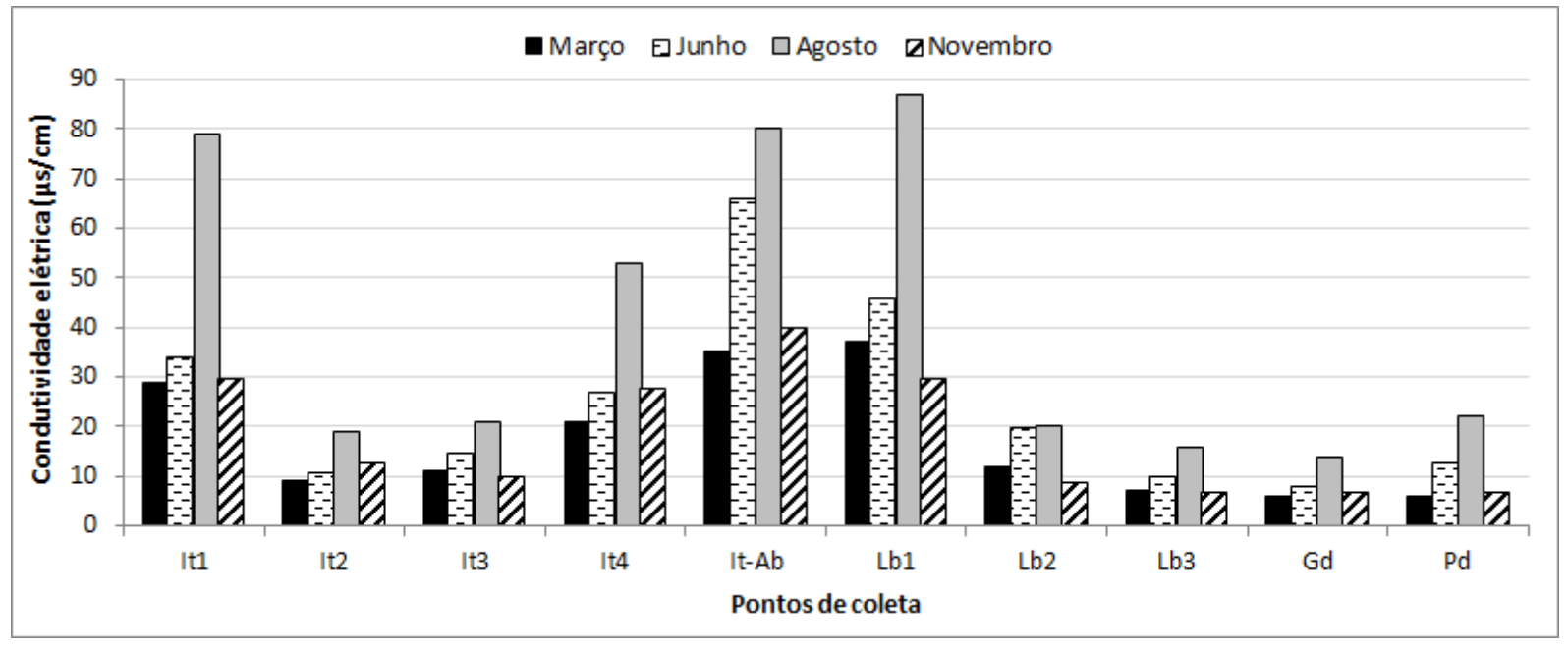

Figura 20 - Variação espacial da condutividade elétrica nos afluentes do Reservatório do Lobo nos meses de março, junho, agosto e novembro de 2012

Nota-se ainda que em todos os pontos de coleta os maiores valores de condutividade ocorreram nas amostragens realizadas no período seco, enquanto os valores do período chuvoso foram significativamente menores. De acordo com Christofoletti (1981), nas épocas chuvosas ocorre uma diminuição da concentração de sais dissolvidos nas águas, em vista do abastecimento acentuado por conta do escoamento superficial, enquanto nas épocas de seca, quando o abastecimento fluvial é mantido pela contribuição subterrânea, a concentração de sais dissolvidos é mais elevada.

Em relação a variável turbidez, foram registrados valores considerados baixos em todas as amostragens. Os maiores valores ocorreram na nascente do Itaqueri, ponto It1, com máximo de 29,9 UNT em novembro. Outro ponto que apresentou valores mais elevados que nos demais é a nascente do Ribeirão do Lobo, ponto Lb1, cujos valores estiveram em torno de 15 UNT nas amostragens em época chuvosa. Em ambos os cursos d'água nota-se um decréscimo nos valores de turbidez no sentido da nascente em direção ao deságue no reservatório.

Verifica-se ainda que em praticamente todas as estações os maiores valores de turbidez ocorreram no período chuvoso, tendo seus máximos na coleta de novembro. Isto pode estar relacionado ao maior carreamento de material dissolvido e em suspensão no período das chuvas, visto que o escoamento superficial nesta época é maior. 


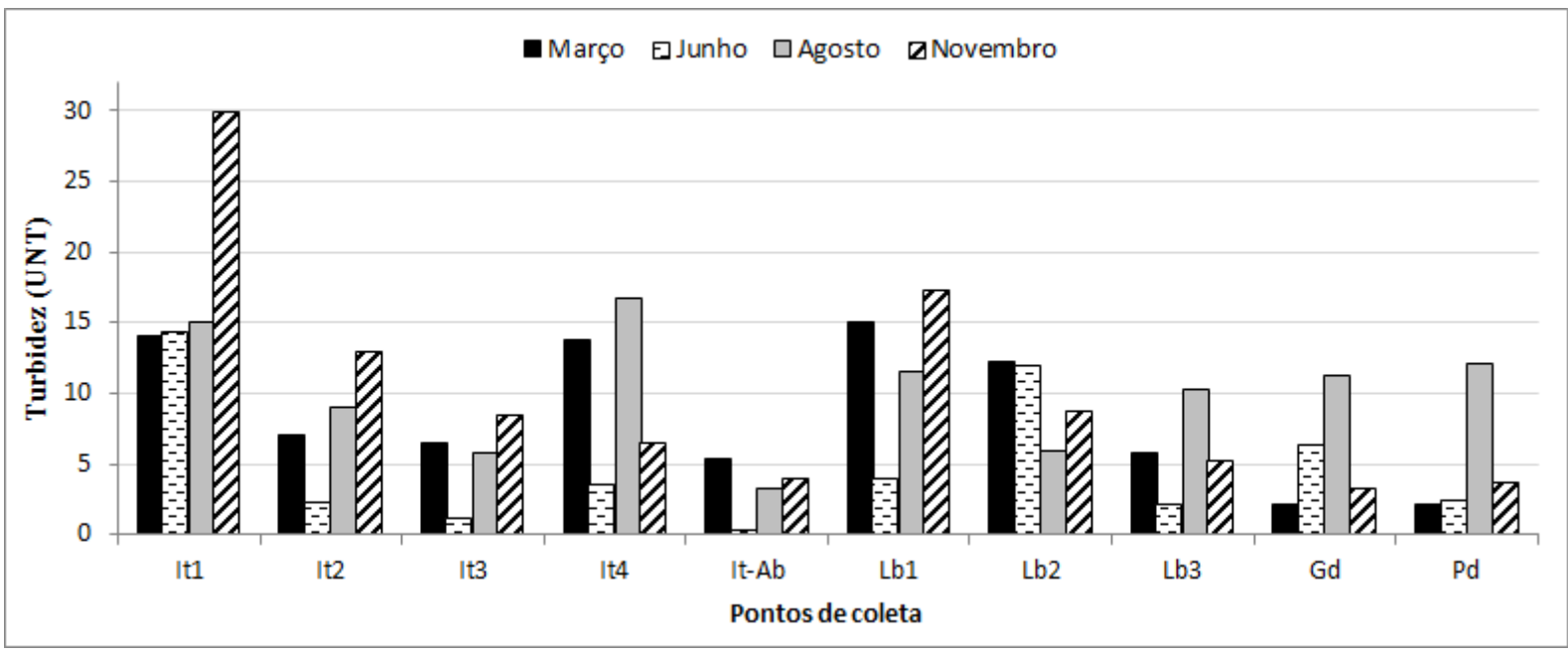

Figura 21 - Variação espacial da turbidez nos afluentes do Reservatório do Lobo nos meses de março, junho, agosto e novembro de 2012

Na Figura 22 são apresentados os resultados obtidos para os sólidos em suspensão durante o período considerado. Verifica-se que a estação de coleta na nascente do Rio Itaqueri (It1) apresentou as maiores concentrações em todas as amostragens, com valores entre 9,1 $\mathrm{mg} / \mathrm{l}$ (em junho) e 15,9 mg/l (em novembro). Após este ponto, foram observados valores elevados na estação Lb1, situada no alto curso do Ribeirão do Lobo, cujos valores estiveram na faixa de 6,2 mg/l (em junho) a 11,3 mg/l (em novembro).

Nas demais estações do Rio Itaqueri e do Ribeirão do Lobo verifica-se uma diminuição dos valores de sólidos suspensos, com concentrações inferiores a $10 \mathrm{mg} / \mathrm{l}$ em todas as amostragens. Nos trabalhos de Reis et al. (2002) e Argenton (2004), realizados tanto em período seco quanto em período chuvoso, também foram verificados baixos valores para diversos pontos amostrados na bacia, não ultrapassando a faixa de $10 \mathrm{mg} / \mathrm{l}$.

Tal como observado com o parâmetro turbidez, a concentração de sólidos em suspensão foi maior na estação chuvosa em praticamente todos os pontos amostrados. Este fato está ligado a maior pluviosidade, o que contribui para o maior carreamento de material alóctone para os cursos d'água da bacia. Já na estação seca, onde geralmente o nível de água é mais baixo, a água torna-se mais limpa por conter pouco material alóctone proveniente da bacia de drenagem.

Segundo Wilson Junior (1996) apud Silva et al. (2003), o material suspenso carregado pelos rios é formado tanto pelas partículas provenientes do próprio leito como por partículas com origem na bacia hidrográfica, sendo que suspensões poluentes podem surgir a qualquer instante, em qualquer segmento do canal, provocando acumulações no trecho. Segundo o 
autor, os materiais poluentes não podem ser caracterizados apenas pela concentração de materiais em suspensão em um dado momento, mas sim por sua variação, ou seja, pelo acréscimo desta concentração no tempo e espaço. Desse modo, para quantificação destas contribuições, é necessário conhecer tanto os picos de transporte em suspensão quanto as características do transporte natural do curso d'água.

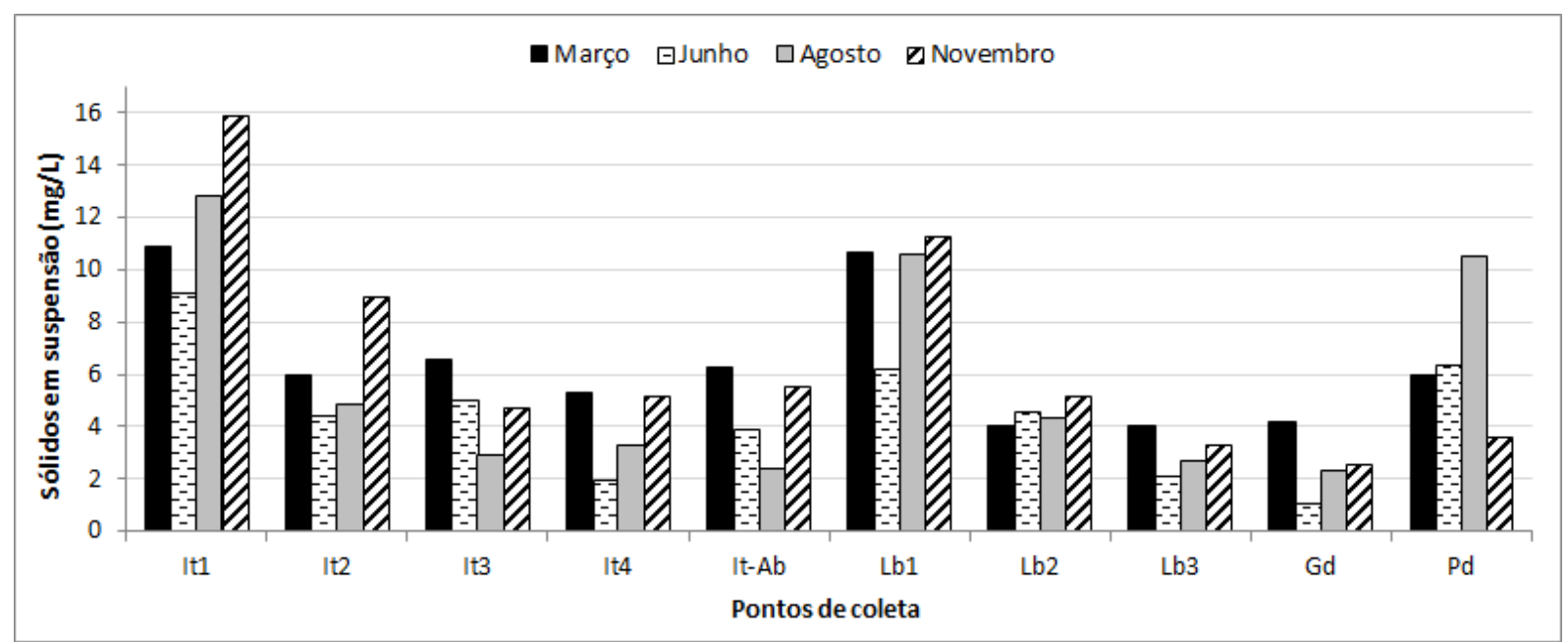

Figura 22 - Variação espacial dos sólidos em suspensão nos afluentes do Reservatório do Lobo nos meses de março, junho, agosto e novembro de 2012

Na Figura 23 são apresentadas as frações de material em suspensão orgânico (MSO) e inorgânico (MSI) referentes às coletas. De modo geral, verifica-se que há o predomínio do transporte de material em suspensão orgânico nos cursos d'água da bacia, em especial no médio e baixo curso dos rios.

Verifica-se que as frações de material suspenso inorgânico são maiores nos pontos de coleta situados na parte alta da bacia (It1 e Lb1), indicando maior contribuição de material alóctone nestes locais. Segundo Carvalho (2011), o predomínio de formas suspensas inorgânicas indica que o material em suspensão constitui-se principalmente de sedimentos ressuspensos ou de partículas inertes provenientes das vertentes próximas ao curso d'água. Como tais estações situam-se em uma área de declives acentuados ocupada por pastagens e plantios de cana-de açúcar, tem-se um maior número de partículas lixiviadas para os cursos d'água, principalmente na época chuvosa, onde o percentual de MSI chega a 77\% na estação It1 em março. 


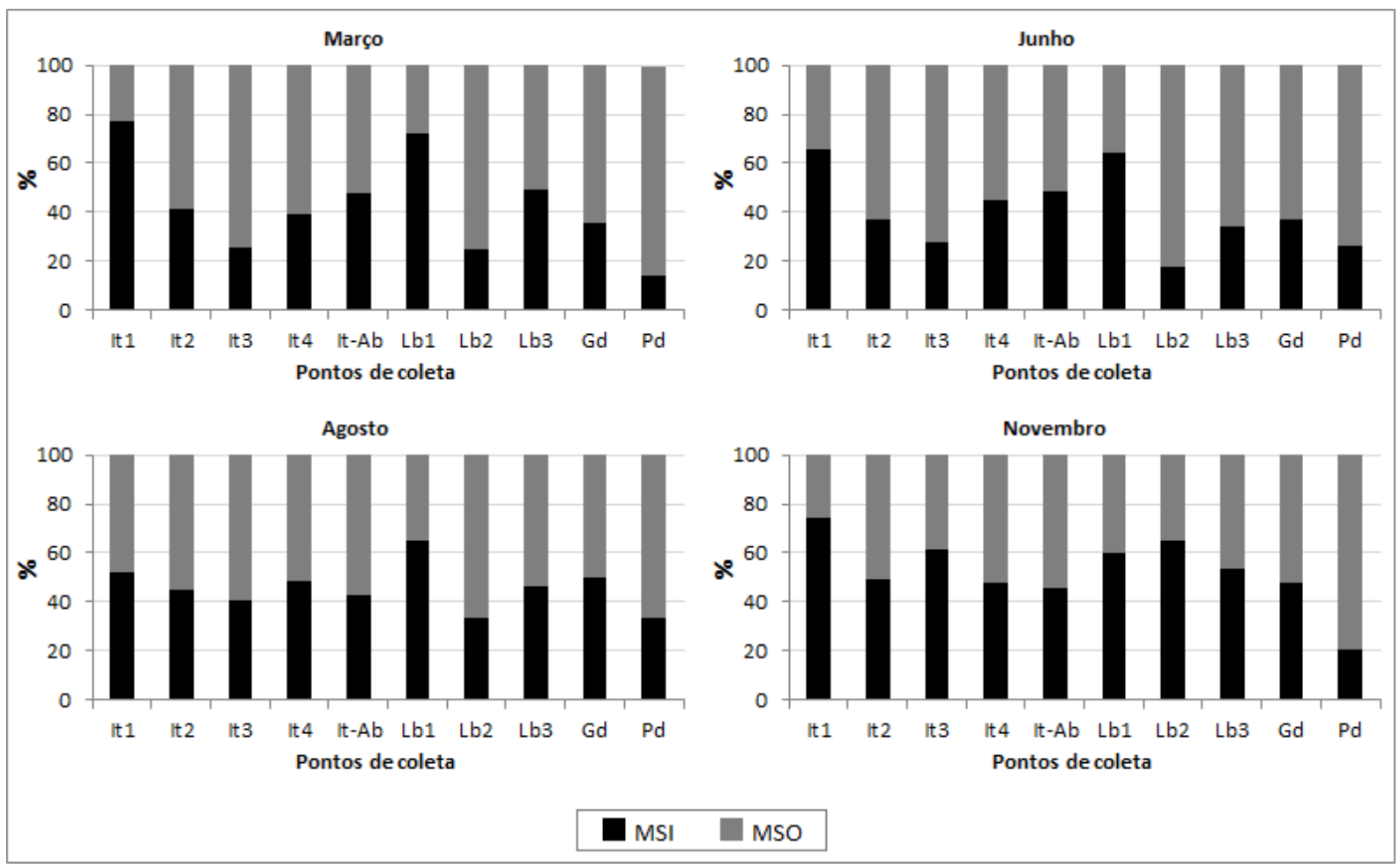

Figura 23 - Frações de material em suspensão orgânico e inorgânico nos afluentes do

Reservatório do Lobo nos meses de março, junho, agosto e novembro de 2012

Nas estações mais a jusante, as frações de MSO tornam-se maiores do que as observadas na nascente, havendo em alguns pontos representatividades similares de MSO e MSI. Os maiores percentuais de MSO foram observados no Córrego das Perdizes, os quais corresponderam a valores superiores a $70 \%$ da composição do material suspenso em todas as datas amostradas. Carvalho (2011) também obteve frações orgânicas bastante significativas para este ponto, especialmente no período seco.

\subsubsection{Análise de componentes principais}

Através da análise de componentes principais realizada com os dados do monitoramento foi possível resumir o conjunto de parâmetros amostrados em um número menor de variáveis. Verificou-se que os componentes principais 1 e 2 apresentaram autovalores de 2,16 e 1,49, sendo estes retidos para interpretação dos dados. Estes dois fatores explicaram, respectivamente, $36,02 \%$ e $24,93 \%$ da variabilidade dos dados, totalizando conjuntamente $60,95 \%$ da variabilidade total.

As variáveis SST, turbidez e condutividade apresentaram correlação negativa com o primeiro componente $(-0,83,-0,65$ e $-0,61$, respectivamente), enquanto o oxigênio dissolvido 
apresentou correlação positiva com este componente $(0,65)$. Já as variáveis temperatura e pH apresentaram correlação negativa com a segunda componente, com valores de $-0,80$ e $-0,45$, respectivamente. Portanto, verifica-se que no primeiro componente houve uma forte ordenação dos resultados em relação aos valores de SST e turbidez, enquanto o segundo componente foi fortemente influenciado pela temperatura.

A Figura 24 apresenta o diagrama de distribuição das estações de amostragem em relação aos componentes, onde cada ponto do diagrama representa uma coleta realizada em determinada estação de amostragem.

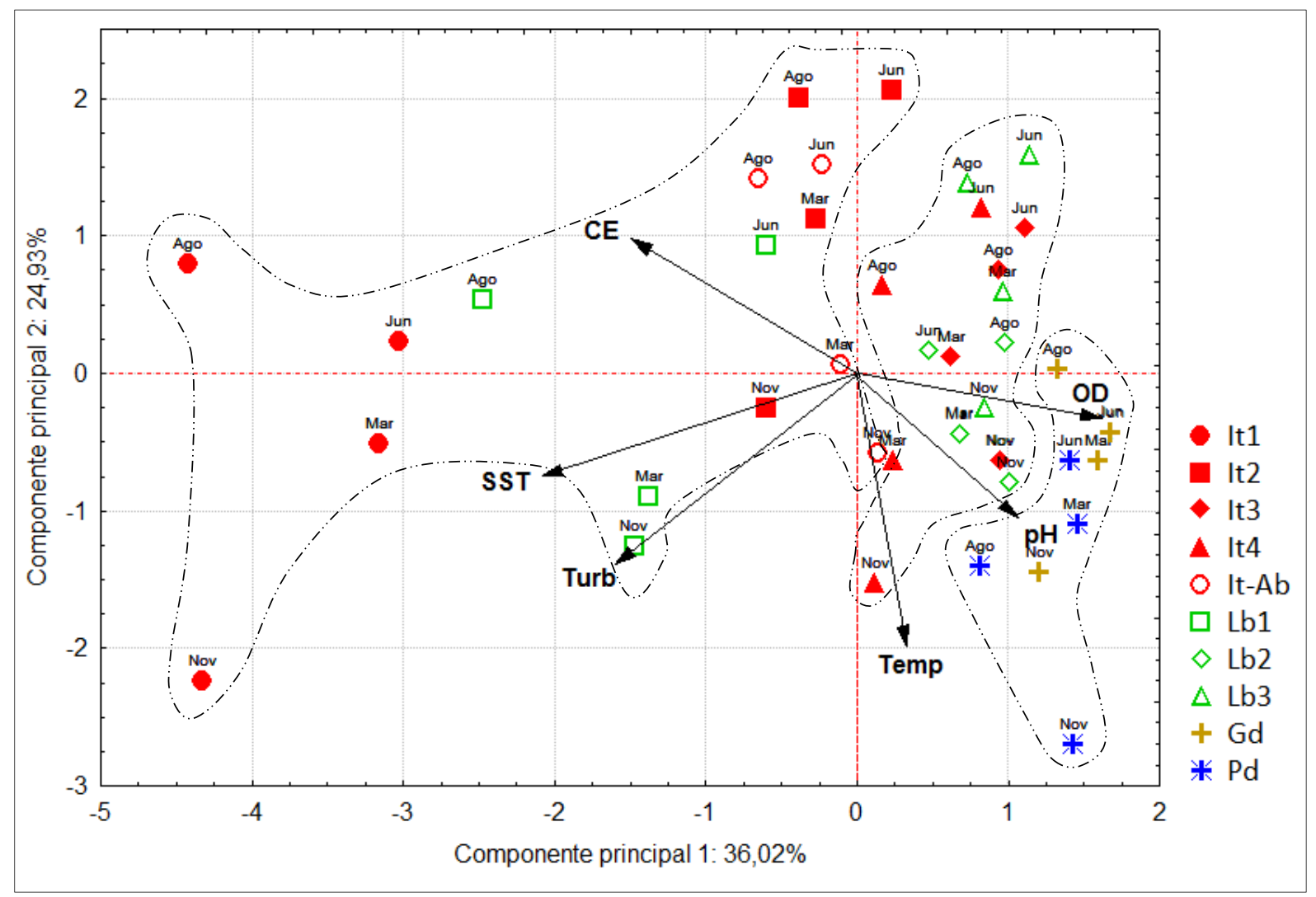

Figura 24 - Análise de componentes principais realizada a partir dos dados de monitoramento de qualidade da água. Ordenação por estações de amostragem

Através do diagrama podem ser observados vários aspectos já discutidos anteriormente em relação às estações de coleta. As estações It1, Lb1, It2 e It-Ab apresentam todas suas coletas posicionadas na parte negativa da primeira componente, indicando os maiores valores de SST e turbidez observados nestes locais. Em contra partida, nestes locais foram observados menores valores de OD, enquanto nas estações Gd e Pd, posicionadas no extremo esquerdo do diagrama, observou-se os maiores valores de tal variável. 
Os valores de condutividade apresentaram comportamento semelhante ao observado com os sólidos e a turbidez na análise exploratória. A ocorrência de elevadas condutividades nos pontos It1, Lb1, It2 e It-Ab pode ter relação com o maior aporte de materiais nestes locais, ocasionando um aumento de eletrólitos na água.

A temperatura, fortemente relacionada com a segunda componente, ocasionou um ordenamento sazonal das coletas em relação a este eixo. As amostragens realizadas na época seca (junho e agosto) concentraram-se predominantemente na parte positiva do eixo, enquanto as amostragens em época chuvosa (março e novembro) na parte negativa, posicionando-se portanto na parte inferior do diagrama.

Por fim, em linhas gerais a análise de componentes principais pode ser entendida como um indicador geral da qualidade da água nos tributários da represa, onde verifica-se que as áreas mais impactadas estão situadas no alto curso do Rio Itaqueri e Ribeirão do Lobo, bem

como no Córrego da Água Branca (estações It1, It2, Lb1, e It-Ab). Verifica-se uma melhoria de qualidade em relação aos parâmetros analisados no sentido em direção ao reservatório, evidenciado pelos resultados das estações It3, It4, Lb2 e Lb3.

As estações onde foram observadas menores perturbações em relação aos parâmetros monitorados foram no Córrego do Geraldo e no Córrego das Perdizes (Gd e Pd), sendo a melhor qualidade observada decorrente da menor área drenada por estas bacias, onde são observados menores índices de urbanização e de atividades agropecuárias.

\subsection{Vazão e descarga de sólidos em suspensão}

Na Figura 25 são apresentados os valores de vazão medidos durante as coletas. Nos pontos de amostragem do Córrego das Perdizes e do Córrego do Geraldo não foi possível a medição da vazão, visto que tais áreas apresentam-se rodeadas por brejos com alta vegetação, não permitindo a delimitação correta do fluxo de água. Na estação It1, nascente do Itaqueri, devido à pequena profundidade do canal, também não foi possível a medição com molinete hidrométrico. 


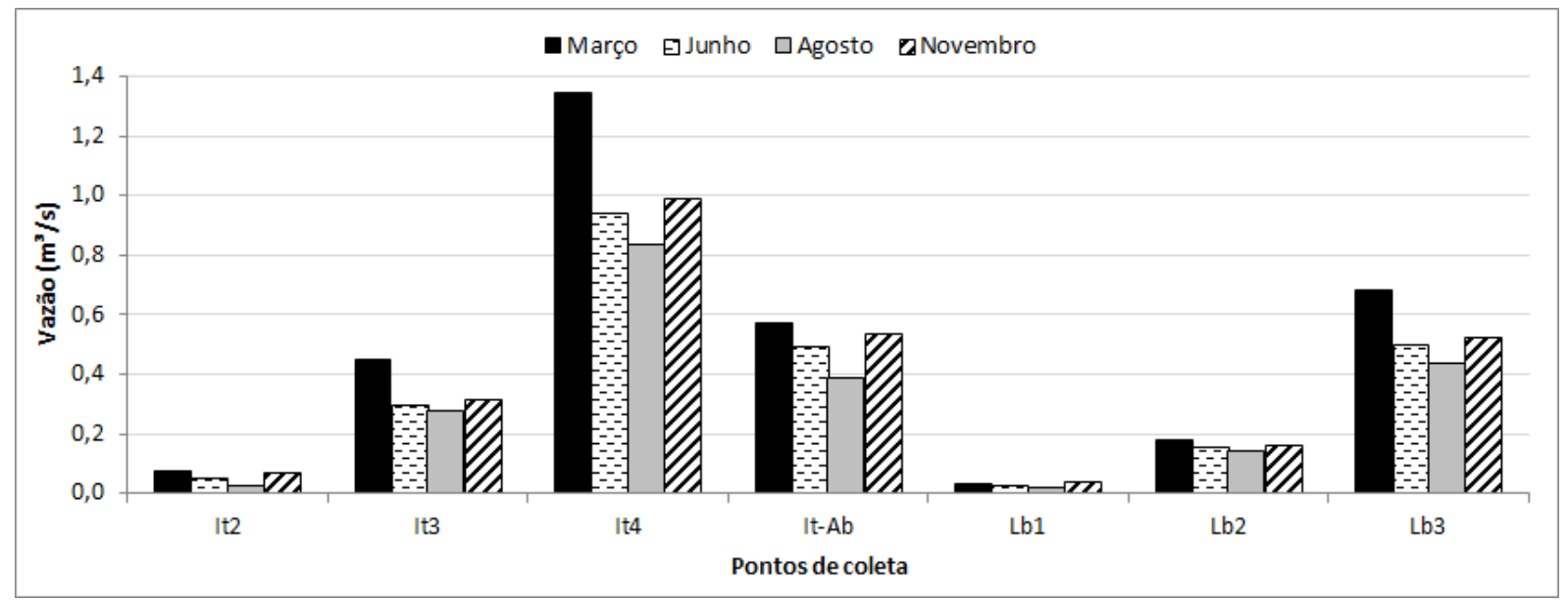

Figura 25 - Vazão nas estações de amostragem do Rio Itaqueri e do Ribeirão do Lobo nos meses de março, junho, agosto e novembro de 2012

Conforme esperado, verifica-se um incremento de vazão no sentido nascente-foz, tanto no Itaqueri como no Lobo. A maior descarga no reservatório provém do Rio Itaqueri, que apresentou uma vazão média de $1,03 \mathrm{~m}$ 3/s na estação It4, enquanto a desembocadura do Ribeirão do Lobo (Lb3) apresentou uma média de $0,53 \mathrm{~m} 3 / \mathrm{s}$. Os maiores valores de vazão para estes pontos ocorreram no mês de março, sendo de $1,34 \mathrm{~m}^{3} / \mathrm{s}$ para o Itaqueri e $0,68 \mathrm{~m}^{3} / \mathrm{s}$ para o Lobo, enquanto as mínimas ocorreram em agosto $\left(0,83 \mathrm{~m}^{3} / \mathrm{s}\right.$ e $0,43 \mathrm{~m} / \mathrm{s}$, respectivamente).

A partir dos dados de vazão e de sólidos em suspensão medidos calculou-se a carga de sedimentos em suspensão, ou seja, a quantidade de material suspenso carregado em um determinado período de tempo, cujo resultado é apresentado na Tabela 12.

Tabela 12 - Carga de sedimentos em suspensão das estações de amostragem do Rio Itaqueri e do Ribeirão do Lobo nos meses de março, junho, agosto e novembro de 2012

\begin{tabular}{ccccc}
\hline \multirow{2}{*}{ Estação } & \multicolumn{3}{c}{ Carga de sedimentos em suspensão (kg/dia) } \\
\cline { 2 - 5 } & Março & Junho & Agosto & Novembro \\
\hline It2 & 39,1 & 21,4 & 11,8 & 53,1 \\
It3 & 256,6 & 129,0 & 69,6 & 131,6 \\
It4 & 613,4 & 163,3 & 239,6 & 446,5 \\
It-Ab & 311,2 & 168,0 & 80,7 & 257,5 \\
Lb1 & 28,1 & 13,7 & 19,3 & 38,9 \\
Lb2 & 61,5 & 63,2 & 52,0 & 72,3 \\
Lb3 & 240,3 & 90,8 & 101,0 & 153,2 \\
\hline
\end{tabular}


Verifica-se que as maiores cargas em suspensão ocorreram na desembocadura do Rio Itaqueri, estação It4, onde foi observado o valor máximo de 613,4 kg/dia na coleta de março. $\mathrm{Na}$ estação seca, a carga de sedimentos suspensos carregada neste ponto foi de 163,3 kg/dia em junho e 239,6 kg/dia em agosto, voltando a aumentar em dezembro para 446,5 kg/dia.

O aporte de sedimentos em suspensão através do Ribeirão do Lobo foi de 240,3 kg/dia em março e 153,2 kg/dia em novembro, enquanto na estação seca foi de 90,8 kg/dia em junho e 101,0 kg/dia em agosto. Desse modo, verifica-se que a descarga em suspensão do Ribeirão do Lobo na estação chuvosa chega a ser quase três vezes menor do que a descarga obtida para o Rio Itaqueri, evidenciando a grande contribuição deste tributário para o aporte de sedimentos no reservatório do Broa.

No trabalho realizado por Argenton (2004), a autora obteve valores de descarga sólida em suspensão de 880,6 kg/dia no mês de dezembro e 39,3 kg/dia no mês de setembro, em uma seção próxima à foz do Rio Itaqueri. No Ribeirão do Lobo, verificou-se valores de 241,3 $\mathrm{kg} /$ dia em dezembro e $23,2 \mathrm{~kg} /$ dia em setembro, sendo tais resultados compatíveis com a faixa de valores obtida neste trabalho.

Ainda segundo a autora citada, o porte diferenciado dos rios da bacia é o principal responsável pela variação de cargas observada, sendo a diferença entre as concentrações de SST pouco representativa. Neste trabalho constatou-se fato semelhante, visto que as estações mais próximas das nascentes (pontos It2 e Lb1) - onde foram observados maiores valores de sólidos em suspensão - em termos de carga transportada foram pouco representativas, devido à pequena vazão do canal nestes locais.

É necessário enfatizar que os resultados de carga sólida em suspensão aqui apresentados, embora tenham sua importância, devem ser considerados como um retrato momentâneo do transporte nos canais, não podendo ser considerados como valores representativos para as estações seca e chuvosa, tampouco permitem inferir estimativas a respeito do total anual de sedimentos em suspensão transportado, visto o reduzido número de amostragens realizadas.

De acordo com Walling e Webb (1987), parte significativa do transporte de sedimentos se dá de forma episódica, ocorrendo principalmente durante eventos extremos de precipitação. Portanto, para a quantificação da produção de sedimentos decorrente destes eventos, é de fundamental importância que sejam feitas amostragens nas vazões de pico.

Bicalho (2006), avaliando a descarga sólida em suspensão de uma bacia predominantemente agrícola situada no Distrito Federal, obteve descargas variando entre 540 $\mathrm{kg} /$ dia, com uma vazão de $0,95 \mathrm{~m}^{3} / \mathrm{s}$, a $130.750 \mathrm{~kg} / \mathrm{dia}$, em um evento cuja vazão alcançou 
$11,5 \mathrm{~m}^{3} / \mathrm{s}$. Poletto (2007) obteve cargas variando de $840 \mathrm{~kg} / \mathrm{dia}$ (vazão de $3,37 \mathrm{~m}^{3} / \mathrm{s}$ ) a 43.400 kg/dia (vazão de 15,08 m³/s) na bacia do Rio São Francisco Falso, no Paraná. Estes trabalhos comprovam a importância da medição da descarga associada a eventos extremos de precipitação, visto o aumento significativo do transporte nessas situações.

Embora as amostragens realizadas neste trabalho sejam referentes a períodos onde o fluxo é predominantemente alimentado pelo escoamento de base, é possível comparar estes resultados com os valores de aporte anual de sedimentos simulados pelo modelo SWAT, apresentados na Tabela 11. Na simulação realizada, verificou-se que o aporte anual de sedimentos no reservatório através do Rio Itaqueri é de 50.866 toneladas, enquanto pelo Ribeirão do Lobo chegam um total de 19.551 toneladas, um valor quase três vezes menor do que o primeiro. Desse modo, os resultados observados nas medições apresenta uma tendência que vai ao encontro dos valores obtidos por modelagem, colocando o Rio Itaqueri como o principal contribuinte no aporte de sedimentos ao reservatório.

Apesar de os valores obtidos para a carga diária parecerem pequenos diante do total anual simulado, é necessário enfatizar que estes resultados refletem apenas as condições ocorrentes no momento de coleta, pois o número reduzido de amostragens não permite uma melhor caracterização da vazão e da carga de material suspenso, principalmente no que se refere à sazonalidade.

Por outro lado, ao calcular a produção de sedimentos por evento chuvoso através da MUSLE, o SWAT considera na modelagem a influência da sazonalidade das chuvas na produção total anual, visto que um dos dados necessários ao funcionamento do modelo são as séries históricas de precipitação diária. Portanto, o simulador consegue prever a contribuição dos eventos extremos de chuva no montante de sedimentos produzidos na bacia, eventos estes que, conforme visto no trabalho de Bicalho (2006), podem ocasionar um aumento de até 250 vezes na carga em suspensão, sendo responsáveis por uma alta parcela do total anual de sedimentos produzidos.

Ademais, é necessário salientar que a produção de sedimentos calculada pelo simulador SWAT engloba um conjunto de processos hidrossedimentológicos que ocorrem tanto na bacia quanto no curso d'água. Além de considerar o sedimento proveniente das vertentes, o simulador também opera computando o balanço de sedimentos dentro do próprio canal, os quais são controlados pelos processos de degradação e deposição. Desse modo, são consideradas não somente a carga de sedimentos em suspensão, mas também o sedimento de fundo depositado e removido em cada trecho do rio. 


\subsection{Análise granulométrica}

Na Figura 26 são apresentados os resultados da análise granulométrica realizada a partir de amostras de sedimento de fundo coletadas nos meses de junho e novembro de 2012, representando os períodos seco e chuvoso.

Como tendência geral, verifica-se que em todas as estações há o predomínio de materiais de granulometria arenosa, onde as frações com as maiores porcentagens correspondem a areia média e areia fina, respectivamente. Tal fato está associado à composição granulométrica dos solos da bacia, visto que na área ocorrem grandes extensões de Neossolos Quartzarênicos, os quais, segundo o levantamento realizado por Oliveira e Prado (1984), possuem teor de areia superior a $85 \%$.

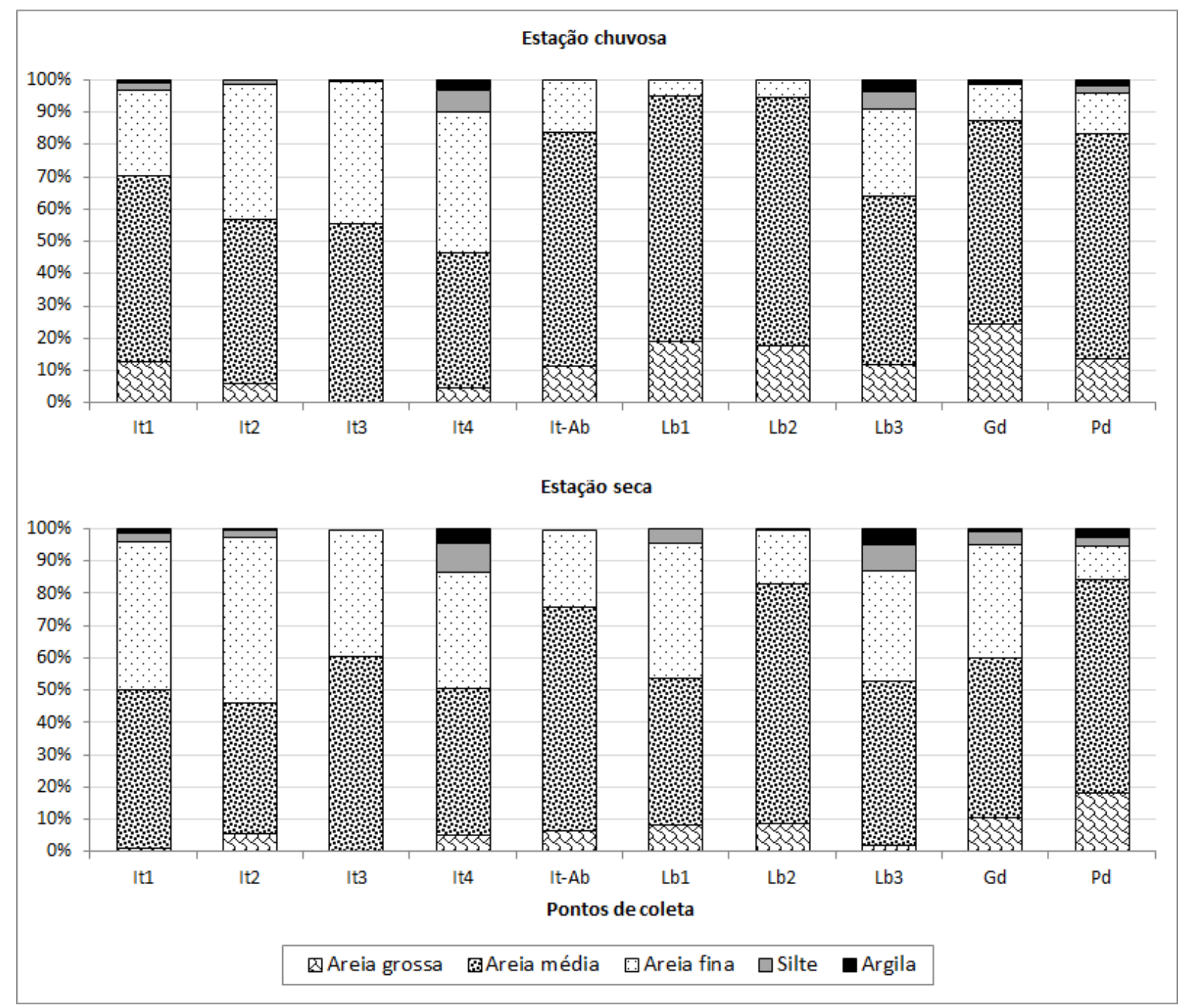

Figura 26 - Frações granulométricas do sedimento nos afluentes do Reservatório do Lobo nos meses de março e novembro de 2012 
As frações mais finas somadas (argila e silte) ocorreram em porcentagens pouco expressivas, inferiores a $15 \%$ em todas as estações de amostragem, com os maiores valores sendo observados na foz dos principais rios. As porcentagens mais elevadas para a fração silte ocorreram durante a coleta em época seca nos pontos It4 e Lb3, correspondendo a 9,1 e 8,2\% dos grãos, respectivamente, enquanto a fração argila ocorreu em porcentagens de 4,7\% e 5,1\% nestes mesmos pontos.

Nas estações localizadas no alto e médio curso do Rio Itaqueri, bem como no Ribeirão do Lobo, não foram encontradas porcentagens significativas de areia e silte, sendo o sedimento nestes locais formado predominantemente por areia fina e média, com menores frações de areia grossa. Segundo Brigante e Espíndola (2003), a maior turbulência provocada pelo fluxo de água no alto curso dos rios possui velocidade suficiente para suspender as frações mais finas do sedimento, carreando-as ao longo do curso d'água em direção à foz. Desse modo, nas áreas mais próximas das nascentes, apenas as frações mais grossas são encontradas em maior quantidade.

Nas Figuras 27 e 28 são exibidos os perfis longitudinais do Rio Itaqueri e do Ribeirão do Lobo, com as localizações das estações de amostragem de sedimento. Em ambos os cursos d'água verifica-se a configuração de um perfil tipicamente côncavo, com declividades maiores em direção à nascente e menores em direção à foz.

Através dos perfis verifica-se que as estações It1, It2 e Lb1 situam-se na parte mais acidentada da bacia, onde o canal possui menor profundidade, menor largura e maior inclinação, resultando em maior turbulência. Nestes locais diz-se que o canal possui alta competência, ou seja, possui uma maior capacidade de transportar sedimentos. De acordo com Christofoletti (1981), a composição granulométrica do material de fundo está relacionada à rugosidade do leito, a qual por sua vez exerce forte influência sobre a turbulência do fluxo no fundo do canal. Conforme se aproxima da foz, ocorrem mudanças na rugosidade do leito e na hidráulica do canal, o que implica na alteração da competência do rio, resultando em uma diminuição desta. Desse modo, existe a tendência de decréscimo gradativo do tamanho dos sedimentos que compõem o material de fundo, conforme foi observado nas estações próximas a foz (It4 e Lb3).

Ainda segundo Christofoletti (1981), a abrasão e o selecionamento são outros processos que permitem explicar a progressiva diminuição do material de fundo à jusante. A abrasão consiste na redução do tamanho das partículas através de processos mecânicos, tais como choques e atritos com outras partículas, enquanto o selecionamento resulta do transporte diferenciado das partículas conforme suas faixas granulométricas. A redução abrasiva das 
partículas sedimentares durante o transporte é considerada por Rana et al. (1973) como o fenômeno de maior influência nesta diminuição granulométrica.

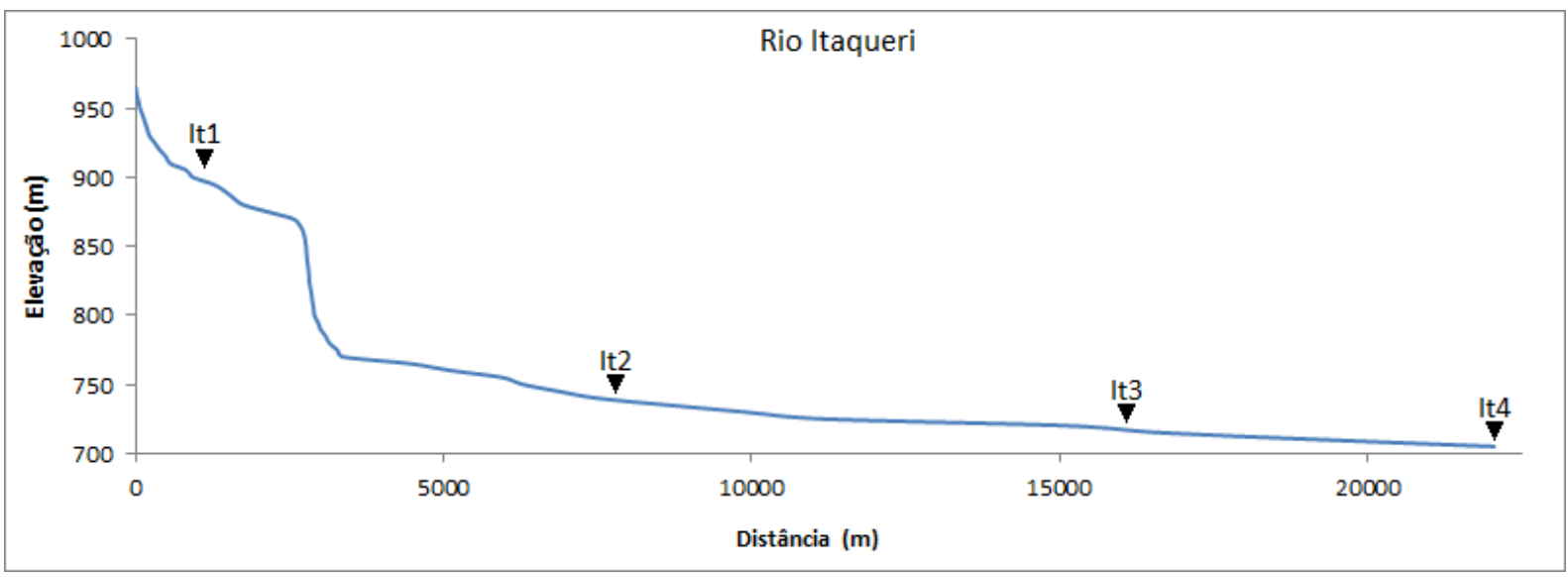

Figura 27 - Perfil longitudinal do percurso do Rio Itaqueri, com as respectivas estações de amostragem

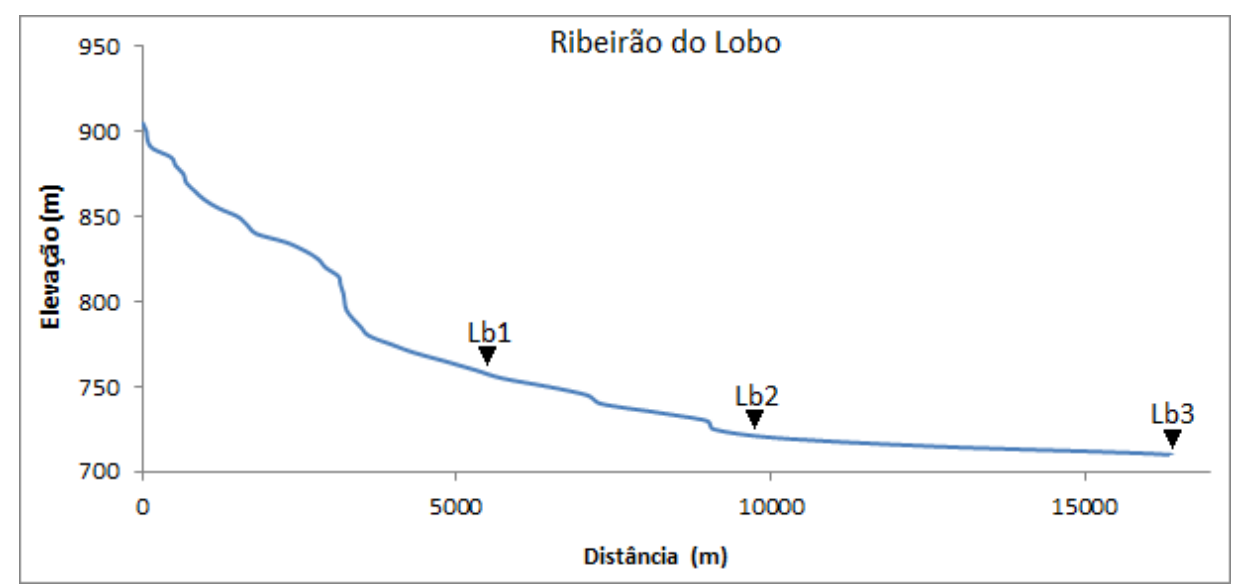

Figura 28 - Perfil longitudinal do percurso do Ribeirão do Lobo, com as respectivas estações de amostragem

Observou-se também que as porcentagens das frações mais finas foram ligeiramente maiores na estação seca quando comparadas às porcentagens obtidas durante a estação chuvosa, o que pode estar ligado ao incremento na velocidade do fluxo d'água por conta das chuvas, carreando as partículas mais finas rio abaixo em direção ao reservatório. Tal fato também foi observado por Carvalho (2011) em amostragens de sedimento de fundo na Bacia do Lobo, sendo tal diferença na composição entre as estações atribuída às chuvas.

Os resultados referentes a granulometria obtidos nesta pesquisa corroboram com outros trabalhos realizados na bacia do Broa. Delello (2008), analisando o sedimento de fundo 
dos tributários do reservatório, observou que a composição dos sedimentos apresentou maior contribuição de areia fina e areia média, enquanto a fração argila foi encontrada em menor proporção. Medeiros (2011) obteve maiores porções de areia fina em estações de amostragem próximas ao reservatório, encontrando maiores porções de silte e argila em pontos localizados na região central da represa.

Diante dos resultados observados, verifica-se que a bacia do Rio Itaqueri apresenta três compartimentos distintos relativos à dinâmica hidrossedimentológica. As áreas altas da bacia correspondem a regiões de maior produção de sedimentos, apresentando valores elevados de sólidos em suspensão no canal mesmo em épocas de maior contribuição do fluxo de base. Apesar das pequenas vazões obtidas nestes locais, a maior velocidade e turbulência do escoamento ocasionam o transporte em suspensão das partículas de menor diâmetro em direção à foz, fazendo com que no leito predominem frações de maior granulometria, como areia média e grossa.

Nas áreas de médio curso ocorre um incremento da vazão dos cursos d'água, havendo um consequente aumento da carga de sedimentos transportada. Nestas regiões, geralmente há um equilíbrio entre a erosão ocorrente no canal e a deposição, resultado dos menores gradientes de declividade.

As áreas de baixo curso correspondem a regiões mais planas, que recebem sedimentos provenientes das áreas de maior altitude, sendo parte destes acumulada nas planícies de inundação. Nestas áreas, a velocidade do fluxo observada foi menor, porém a vazão, bem como a carga de sedimentos em suspensão transportada, são mais elevadas. Devido à menor energia fluvial desses locais, parte do material em suspensão transportado se sedimenta, o que explica as frações mais elevadas de argila e silte no material de fundo, em comparação com pontos no alto e médio curso. 


\section{CONSIDERAÇÕES FINAIS}

A integração dos diversos elementos de análise contemplados nesta pesquisa visou realizar um diagnóstico tendo como foco as etapas de produção e de transporte de sedimentos na bacia do Rio Itaqueri, o que possibilitou obter informações importantes a respeito de sua dinâmica hidrossedimentológica. A modelagem da produção de sedimentos utilizando a interface disponível em SIG, associada aos elementos de limnologia, hidrossedimentologia e de geomorfologia fluvial abordados no decorrer do trabalho denotam o enfoque multidisciplinar envolvido no estudo dos processos de erosão e produção de sedimentos.

A simulação realizada através do SWAT permitiu avaliar a produção de sedimentos na bacia através de sua subdivisão em bacias menores, o que evidenciou a existência de áreas com diferentes potenciais de geração de sedimento. Verificou-se que poucas áreas foram responsáveis pelos maiores valores de sedimentos produzidos, a exemplo das sub-bacias localizadas na parte alta da bacia, onde foram obtidos médios anuais de até 18 t/ha, o que evidencia a maior criticidade destas áreas. De modo geral, a produção anual média de sedimentos observada na bacia foi considerada baixa quando comparada com outros trabalhos que utilizaram o simulador.

O SWAT mostrou-se como um modelo bastante completo para avaliação da produção de sedimentos, englobando diversos processos físicos que ocorrem nas bacias hidrográficas. Além da produção de sedimentos por sub-bacia, foi possível obter estimativas referentes a alguns parâmetros do balanço hídrico. A simulação também permitiu estimar a contribuição de cada um dos afluentes da bacia para o aporte de sedimentos no reservatório, onde verificou-se que o Rio Itaqueri responde por $65 \%$ do total de sedimento, seguido pelo Ribeirão do Lobo, com $25 \%$ do total.

Por se tratar de uma bacia não instrumentada do ponto de vista sedimentológico, onde os poucos postos fluviométricos encontram-se desativados e postos hidrossedimentométricos são inexistentes, não foi possível realizar o processo de calibração e validação dos resultados obtidos pelo modelo. Entretanto, as amostragens realizadas nos afluentes do reservatório foram consistentes com os resultados obtidos na modelagem. O Rio Itaqueri configurou-se como o principal contribuinte para o aporte de sedimentos na bacia, chegando a apresentar o triplo da carga sólida em suspensão carregada pelo Ribeirão do Lobo nas coletas realizadas em estação chuvosa. 
A análise conjunta dos resultados modelados, das variáveis limnológicas amostradas e do sedimento de fundo permitiu inferir afirmações sobre a dinâmica dos sedimentos no canal. A parte alta da bacia configurou-se como uma área de aporte de sedimentos, os quais, devido à maior turbulência do fluxo, são selecionados e transportados em direção à foz. Nas áreas mais baixas, onde a energia de transporte é menor, ocorre a deposição de parte destes sedimentos, tanto na planície fluvial do Rio Itaqueri como na Represa do Lobo.

Uma ressalva importante a ser feita com relação a este trabalho é a ausência de amostragens junto a ocorrência de eventos de chuva, visto que durante esses eventos têm-se a maior parcela de sedimentos carregada para os cursos d'água. Além disso, o pequeno número de amostragens realizado não permite uma caracterização completa da descarga sólida dos rios. Desse modo, como sugestão para trabalhos futuros, seria de grande interesse a continuidade do monitoramento nas seções amostradas, com vistas a obter um maior número de amostragens, tanto em estiagem quanto próximas a eventos chuvosos, de forma a realizar o traçado de uma curva-chave de sedimentos.

Neste trabalho foram amostradas variáveis sedimentológicas de obtenção relativamente simples, como o material em suspensão, a carga sólida suspensa e a granulometria do leito. Desse modo, em estudos futuros voltados à caracterização sedimentológica da bacia, seria de grande valia a determinação de variáveis de maior complexidade, a exemplo da granulometria do material em suspensão, a obtenção de taxas de sedimentação no reservatório utilizando câmaras de sedimentação, as estimativas da carga de leito e a determinação da carga sólida total.

Através dos resultados obtidos por esta pesquisa, foi possível identificar na bacia do Rio Itaqueri áreas com diferentes comportamentos hidrossedimentológicos, permitindo-se identificar os locais que mais contribuem com a produção de sedimentos. A obtenção deste cenário é de extrema importância no planejamento conservacionista da bacia, visto que sinaliza áreas que devem ser atendidas prioritariamente, de modo a definir sua capacidade de uso conforme as fragilidades detectadas. Além disso, o manejo adequado destas áreas permitirá menor dinâmica erosiva dos solos, evitando o carreamento de sedimentos para os corpos d'água e, consequentemente, diminuindo seu aporte no Reservatório do Broa. 


\section{REFERÊNCIAS BIBLIOGRÁFICAS}

AMERICAN PUBLIC HEALTH ASSOCIATION (APHA). Standart Methods for the Examination of Water and Wastewater. 19ª ed. Washington, D. C., 1995. 1155p.

ARGENTON, E. C. Limnologia, balneabilidade e impactos ambientais: uma análise temporal e espacial na represa do Lobo (Broa), Itirapina/Brotas - SP. 146p. Dissertação (Mestrado em Ciências da Engenharia Ambiental.) - Escola de Engenharia de São Carlos, Universidade de SãoPaulo, São Carlos, 2004.

ARNOLD, J. G. et al. Large area hydrologic modeling and assessment. Part I: model development. JAWRA, v. 34, n. 1, p. 73-89, 1998.

AZEVEDO, E. S. Projeto viva o Broa - integração de municípios para a construção de alternativas de gestão dos recursos naturais e d o controle da água na Represa do Lobo (Brotas - Itirapina - São Carlos/SP), promotoras do desenvolvimento local. Anais Rede Waterlat Conferência Internacional, São Paulo, 2010.

BAGNOLD, R. A. Bedload transport in natural rivers. Water Resources Res. v.13, n. 2, p. 303-312, 1977.

BALDISSERA, G. C. Aplicabilidade do modelo de simulação hidrológica SWAT para a bacia hidrográfica do Rio Cuiabá/MT. 2005. 144 p. Dissertação (Mestrado em Física e Meio Ambiente) - Instituto de Ciências Exatas e da Terra, Universidade Federal do Mato Grosso, Cuiabá, 2005.

BALTOKOSKI, V. et al . Calibração de modelo para a simulação de vazão e de fósforo total nas sub-bacias dos Rios Conrado e Pinheiro - Pato Branco (PR). Rev. Bras. Ciênc. Solo, Viçosa, v. 34, n. 1, 2010.

BERTONI, J. C.; LOMBARDI NETO, F. Conservação do solo. $5^{\text {a }}$ ed. São Paulo: Ícone Editora, 2005. 355 p. 
BERTONI, J. C.; TUCCI, C. E. M. Precipitação. In: TUCCI, C. E. M. Hidrologia: Ciência e Aplicação. Porto Alegre: Editora da Universidade Federal do Rio Grande do Sul, 1993. p. 177-241.

BICALHO, C. C. Estudo do transporte de sedimentos em suspensão do Rio Descoberto. 2006. 123 p. Dissertação (Mestrado em Ciência) - Universidade de Brasília, Distrito Federal, 2006.

BITTENCOURT, G. A., et al. Desenvolvimento de modelo matemático de qualidade da água para a implantação da agência de bacia do Rio das Velhas. In: $19^{\circ}$ CONGRESSO BRASILEIRO DE ENGENHARIA SANITÁRIA AMBIENTAL, Foz do Iguaçu, 1997. Anais... Foz do Iguaçu: ABES,1997.

BOURAOUI, F. et al. Application of the SWAT model on the Medjerda river basin (Tunisia). Physics and Chemistry of the Earth Journal, v. 30, p. 497-507, 2005.

BORDAS, M. P.; SEMMELMANN, F. R. Elementos de engenharia de sedimentos. In: TUCCI, C. E. M. Hidrologia: Ciência e Aplicação. $2^{\mathrm{a}}$ ed. Porto Alegre: Editora da Universidade Federal do Rio Grande do Sul, 2001. p. 915-943.

BREDA, A. Avaliação de melhorias para um sistema de previsão hidrológica horária. 2008. Dissertação (Mestrado em Engenharia de Recursos Hídricos e Ambiental) - Setor de Tecnologia, Universidade Federal do Paraná, Curitiba, 2008

BRIGANTE, J. ; ESPÍNDOLA, E. L. G. Limnologia fluvial: um estudo de caso no rio Mogi-Guaçu. São Carlos: RiMa Editora, 2003. 255p

CALIJURI , M. C. Respostas fisioecológicas da comunidade fitoplanctônica e fatores ecológicos em ecossistemas com diferentes estágios de eutrofização. 1988. 292 p. Tese (Doutorado em Hidráulica e Saneamento) - Escola de Engenharia de São Carlos, Universidade de São Paulo, São Carlos, 1988.

CARVALHO, A.E.F. Análise limnológica e ecotoxicológica de sistemas lóticos e lênticos da bacia hidrográfica dos rios Itaqueri e Lobo (Itirapina/Brotas - SP). 2011. 226 p. Dissertação 
(Mestrado em Ciências da Engenharia Ambiental) - Escola de Engenharia de São Carlos, Universidade de São Paulo, São Carlos, 2011.

CARVALHO, N. de O. Hidrossedimentologia prática. 2a ed. Rio de Janeiro: CPRM, 2008. $599 \mathrm{p}$.

CECCHIA, T. Avaliação de perda de solo por erosão hídrica e estudo de energia na bacia do rio Caeté, Alfredo Wagner, Alfredo Wagner - Santa Catarina. 2005. 166 p. Dissertação (Mestrado em Engenharia Ambiental) - Universidade Federal de Santa Catarina, Florianópolis, 2005.

CHEN, E.; MACKAY, D. S. Effects of distribution-based parameter aggregation on a spatially distributed agricultural nonpoint-source pollution model. Journal of Hydrology, v. 295, p. 211-224, 2004.

CHOW, V. T.; MAIDMENT, D. R.; MAYS, L. W. 1988. Applied hydrology. New York: McGraw-Hill. 572 p.

CHRISTOFOLETTI, A. Modelagem de Sistemas Ambientais. São Paulo: Edgar Blücher ltda, 1999.

CHRISTOFOLETTI, A. Geomorfologia Fluvial. v.1. São Paulo: Edgard Blücher, 1981.

COMPANHIA DE PESQUISA DE RECURSOS MINERAIS (CPRM). Mapa Geológico do Estado de São Paulo. Brasília: Ministério de Minas e Energia, 2006. Escala 1:750.000.

COMPANHIA DE PESQUISA DE RECURSOS MINERAIS (CPRM). Geologia, Tectônica e Recursos Minerais do Brasil: Texto, Mapas e SIG. Brasília: CPRM Serviço Geológico do Brasil, 2003. 692 p.

COMPANHIA DE TECNOLOGIA DE SANEAMENTO AMBIENTAL (CETESB). Drenagem Urbana: Manual de Projeto. 2a ed. São Paulo: CETESB, 1980. 468 p. 
COOPERATIVA DE SERVIÇOS E PESQUISAS TECNOLÓGICAS (CPTI) Diagnóstico da Situação dos Recursos Hídricos no Pontal do Paranapanema - Relatório Zero. São Paulo: CPTI, 1998.

CUNHA, M. A.; SANTOS, A. R. Técnicas simples de controle de erosão em estrada de terra. In: III SIMPÓSIO SOBRE CONTROLE DE EROSÃO, 1985, Maringá. Anais... Maringá: ABGE, 1985. p. 91-97.

CUNICO, C.; OKA-FIORI, C. Zoneamento ambiental da bacia hidrográfica do rio MarumbiPR: perspectivas para a análise e avaliação das condições sócio-ambientais. Estudos Geográficos, v. 6, n. 1, p. 37-61, 2008.

DECHEN, S. C. F.; PROCHNOW, D. Erosão e produtividade. O Agronômico, Campinas, v. 55, n. 1, p. 22-24, 2003.

DELELLO, D. Composição e distribuição (espacial e temporal) de macrófitas aquáticas no reservatório do Lobo (Broa), Itirapina, SP. 2008. 156 p. Dissertação (Mestrado em Ciências da Engenharia Ambiental) - Escola de Engenharia de São Carlos, Universidade de São Paulo, São Carlos, 2008.

DE ROO, A. P. J.; JETTEN, V. G. Calibrating and validating the LISEM model for two data sets from the Netherlands and South Africa. Catena : an interdisciplinary journal of soil science, hydrology, geomorphology focusing on geoecology and landscape evolution, v. 37, p. 477-493, 1999.

DELGADO, J. M. et al. Plano de manejo integrado das unidades de Itirapina-SP. IF Série Registros, São Paulo, n. 27, p. 1-153, 2004.

DURÃES, M. F. Caracterização e avaliação do estresse hidrológico da bacia do rio Paraopeba, por meio de simulação chuva-vazão de cenários atuais e prospectivos de ocupação e uso do solo utilizando um modelo hidrológico distribuído. 2010. 147 p. Dissertação (Mestrado em Saneamento, Meio Ambiente e Recursos Hídricos) - Universidade Federal de Minas Gerais, Belo Horizonte, 2010. 
EMBRAPA; SECRETARIA DA AGRICULTURA E ABASTECIMENTO DO EST. DE SÃO PAULO; INSTITUTO AGRONÔMICO DE CAMPINAS (IAC). Levantamento pedológico semi-detalhado do Estado de São Paulo. Campinas: IAC, 1981. Quadrícula de São Carlos, Folha SF 23-Y-A-I. Escala 1:100.000.

EMBRAPA. Sistema Brasileiro de Classificação de Solos. $2^{\mathrm{a}}$ ed. Rio de Janeiro: Embrapa Solos, 2006. 367 p.

ESTADOS UNIDOS. Soil Conservation Service. SCS national engineering handbook: section 4 Hydrology. Washington, 1972.

ESTEVES, F. A. Fundamentos de limnologia. 2a ed. Rio de Janeiro: Interciência, 1998. $602 \mathrm{p}$.

FENDRICH, R.; OBLADEN, N. L.; AISSE, M. M. Drenagem e controle da erosão urbana. $4^{\mathrm{a}}$ ed. Curitiba: Champagnat, 1997. 486 p.

FERREIRA, P. H. de M.. Princípios de manejo e conservação do solo. $2^{\mathrm{a}}$ ed. São Paulo: Nobel, 1981.

FIRMINO, R. G.; FONSECA, M. B. Uma discussão sobre os impactos ambientais causados pela expansão da agricultura: A produção de biocombustíveis no Brasil. In: $7^{\circ}$ CONGRESSO INTERNACIONAL SOBRE GERAÇÃO DISTRIBUÍDA E ENERGIA NO MEIO RURAL, 2008, Fortaleza. Anais... AGRENER GD, 2008.

FLANAGAN, D. C.; NEARING, M. A. USDA Water Erosion Prediction Project: Hillslope Profile and Watershed Model Documentation. NSERL Report n. 10. West Lafayette: USDA-ARS National Soil Erosion Research Laboratory,1995.

FOSTER, G. R. The overland flow processes under natural conditions. In: 3rd INTERNATIONAL SEMINAR FOR HYDROLOGICAL PROFESSORS, 1971, West Lafayette. Biological effects in the hydrological cycle: proceedings. West Lafayette: Purdue University, 1971. p. 173-185. 
FOSTER, G. R. Modeling the erosion process. In: HAAN, C. T.; JOHNSON, H. P.; BRAKENSIEK, D. L. Hydrologic Modeling of small watersheds. St. Joseph: ASAE, 1982. p. 297-380.

FREIRE, O; GIMENEZ, J.; PESSOTI, J. E.; CARRARO, E. Solos da Bacia do Broa. São Carlos: Univ. Fed. São Carlos, 1978. 125 p.

FUJIHARA, A. K. Predição de erosão e capacidade de uso do solo numa microbacia do oeste paulista com suporte de geoprocessamento. 2002. 136 p. Dissertação (Mestrado em Ciência Florestal) - Escola Superior de Agricultura Luiz de Queiroz, Universidade de São Paulo, Piracicaba, 2002.

GARBOSSA, L. H. P. et al. The use and results of the Soil and Water Assessment Tool in Brazil: A review from 1999 until 2010. In: 2011 INTERNATIONAL SWAT CONFERENCE \& WORKSHOPS, 2011, Toledo. 2011 International SWAT Conference \& Workshops. Bryan: Texas A\&M University, 2011.

GASSMAN, P.W. The Soil and Water Assessment Tool: Historical development, applications, and future research directions. Transactions of the American Society of Agricultural and Biological Engineers, St. Joseph, v. 50, p. 1211-1250, 2007.

GOVENDER, M.; EVERSON C. S. Modelling streamflow from two small South African experimental catchments using the SWAT model. Hydrological Processes, Chichester, v. 19, p. 683-692, 2005.

GRANDO, A. Monitoramento e modelagem hidrossedimentológica em uma microbacia hidrográfica experimental. 2011. 174 p. Dissertação (Mestrado em Engenharia Civil) Universidade Federal de Santa Catarina, Florianópolis, 2011.

GROSSI, C. H. Diagnóstico e monitoramento ambiental da microbacia hidrográfica do Rio Queima-Pé, MT. 2006. 135 p. Tese (Doutorado em Agronomia) - Faculdade de Ciências Agronômicas, Universidade Estadual Paulista, Botucatu, 2006. 
GUERRA, A. J. T. Processos Erosivos nas Encostas. In: GUERRA, A. J. T.; CUNHA, S. B. (org.).Geomorfologia: uma atualização de bases e conceitos. $2^{\mathrm{a}}$ ed. Rio de Janeiro: Bertrand Brasil, 1995. 472 p.

GUERRA. A.J.T. O início do processo erosivo. In: GUERRA et al. Erosão conservação do solos: conceitos, temas e aplicações. Rio de Janeiro: Bertrand Brasil, 1999. p.17-55.

GUIMARÃES, R.F. et al. Movimentos de massa. In: FLORENZANO, T.G. (org.). Geomorfologia: conceitos e tecnologias atuais. São Paulo: Oficina de Textos, 2008. 318p.

HARgREAVES, G. L.; HARGREAVES, G. H.; RILEY, J. P. Agricultural benefits for Senegal River Basin. Journal of Irrigation and Drainage Engineering, v. 111, n. 2, p. 113$124,1985$.

HUDSON, N. W. Soil conservation. 2a ed. Ithaca: Cornell University Press, 1973. 320 p.

INSTITUTO DE PESQUISAS TECNOLÓGICAS DO ESTADO DE SÃO PAULO (IPT). Mapa Geomorfológico do Estado de São Paulo. São Paulo: Governo do Estado de São Paulo, 1981. Escala 1:1.000.000.

INSTITUTO DE PESQUISAS TECNOLÓGICAS DO ESTADO DE SÃO PAULO (IPT). Diagnóstico da situação atual dos recursos hídricos e estabelecimento de diretrizes técnicas para a elaboração do Plano da Bacia Hidrográfica do Tietê-Jacaré - Relatório Final. São Paulo: IPT, 2000.

KERTZMAN, F. F.; GOUVEIA, M. I. F.; MANO, V. G. T. Orientações para o combate à erosão no Estado de São Paulo. São Paulo: IPT/DAEE, 1991. v. 1, 102 p.

KNISEL, W. G. CREAMS - a Field Scale Model for Chemicals, Runoff and Erosion from AgriculturalManagement Systems. US Department of Agriculture Research Report, 1985. n 26, 643p.

KRAMER, L. A.; MEYER, L. D. Small ammounts of surface mulch reduce soil erosion and runoff velocity. Transactions of the ASAE, St. Joseph, v. 12, p. 638-641, 1969. 
KREBS, A. S. J. Contribuição ao conhecimento dos recursos hídricos subterrâneos da área correspondente à bacia Hidrográfica do Rio Araranguá, SC. 2002. Proposta de Tese (Doutorado) - Universidade Federal de Santa Catarina, Florianópolis, 2002.

KRONE, R. B. Flume studies of the transport of sediment in estuarial processes, final report. Berkeley: Hydraulic Engineering Laboratory and Sanitary Engineering Research Laboratory, University of California, 1962.

LICK W.; LICK J.; ZIEGLER C. K. Flocculation and its effect on the vertical transport of fine-gained sediments. Hydrobiologia, v. 235, p. 1-16, 1992.

LOMBARDI NETO, F.; BELLINAZZI JUNIOR, R.; GALETI, P. A.; LEPSCH, I. F.; OLIVEIRA, J. B. Nova abordagem para cálculo de espaçamento entre terraços. In: SIMPÓSIO SOBRE TERRACEAMENTO AGRÍCOLA, 1988, Campinas. Anais... Campinas: Fundação Cargill, 1989. p. 99-124.

LOPES, V. L. A numerical model of watershed erosion and sediment yield. Tucson: University of Arizona, 1987.

MACHADO, R.; VETORAZZI, C. A. Simulação da produção de sedimentos para a microbacia hidrográfica do ribeirão dos Marins (SP). Revista Brasileira de Ciência do Solo, Viçosa, v. 27, p. 735-741, 2003.

MATHEUS, C. E.; TUNDISI, J. G. Estudo físico químico e ecológico dos rios da bacia hidrográfica do Ribeirão e represa do Lobo. In: TUNDISI, J. G. (ed). Limnologia e Ecologia de Represas. ACIESP; FAPESP; CNPq; UNEP; UNCRD, 1988. v.1, tomo 1, p.419-472.

MEDEIROS. G. R. Desenvolvimento e distribuição de espécies de macrófitas aquáticas em áreas alagadas da represa do Lobo-Broa (UHE Carlos Botelho) em função do estado trófico. 2011.98 p. Dissertação (Mestrado em Ecologia e Recursos Naturais) - Universidade Federal de São Carlos, São Carlos, 2011. 
MERRIT, W. S.; LETCHER, R. A; JAKEMAN, A. J. A review of erosion and sediment transport models. Environmental Modelling \& Software, v. 18, p. 761-799, 2003.

MINOTTI, R. T. Abordagens Qualitativa e Quantitativade Microbacias Hidrográficas e Áreas Alagáveis de um Compartimento do Médio Mogi-Superior-SP. 2006. 247 p. Tese (Doutorado em Ciências da Engenharia Ambiental) - Escola de Engenharia de São Carlos, Universidade de São Paulo, São Carlos, 2006.

MONTEITH, J. L. The State and Movement of Water in Living Organisms. Swansea: Soc. For Exp. Biol. Cambridge University Press, 1965.

MORGAN, R. P. C.; QUINTON, J. N.; SMITH, R. E. EUROSEM: Documentation and user guide. Silsoe, 1998.

MORO, M. A utilização da interface SWAT-SIG no estudo da produção de sedimentos e do volume de escoamento superficial com simulação de cenários alternativos. 2005. 100 p. Dissertação (Mestrado em Agronomia) - Escola Superior de Agricultura Luiz de Queiroz, Universidade de São Paulo, Piracicaba, 2005.

NETO, J. G. C. Simulação hidrossedimentológica da bacia do Riacho dos Namorados com o modelo SWAT. 2011. 218 p. Dissertação (Mestrado em Engenharia Civil e Ambiental) - Universidade Federal de Campina Grande, Campina Grande, 2011.

NEITSCH, S. L.; ARNOLD, J. G.; KINIRY, J. R.; SRINIVASAN, R.; WILLIAMS, J. R. Soil and water assessment tool: input/output file documentation. Texas: Soil And Water Research Laboratory \& Blackland Research Center, 2005.

NORDIN, C. F.; McQUIVEY, R. S. Suspended load. In : SHEN, H. W. River mechanics. Fort Collins, 1971.

NOVOTNY, V.; OLEM, H. Water quality: Prevention, identification and management of diffuse pollution. New York: Van Nostrand-Reinhold, 1993. 1054 p. 
OLIVEIRA, M. D. Produção primária e estrutura da comunidade fitoplanctônica no reservatório do Lobo (SP): uma comparação entre fatores ecológicos na represa e seus principais tributários. 1993. 178 p. Dissertação (Mestrado em Ciências da Engenharia Ambiental) - Escola de Engenharia de São Carlos, Universidade de São Paulo, São Carlos, 1993.

OLIVEIRA, J. B.; PRADO, H. Levantamento pedológico semidetalhado do Estado de São Paulo: Quadrícula de São Carlos. Memorial descritivo. Campinas: IAC, 1984. 110 p.

OLIVEIRA, M. A. T.; HERRMANN, M. L. P. Ocupação do solo e riscos ambientais na área conurbada de Florianópolis. In: GUERRA, A. J. T.; CUNHA, S. B. (orgs.) Impactos Ambientais Urbanos no Brasil. Rio de Janeiro: Bertrand Brasil, 2001.

OVERTON, D. E. Muskingum flood routing of upland streamflow. Journal of Hydrology, v. 4, p. 185-200, 1966.

PAIM, J. B. Avaliação do potencial de produção de sedimentos na bacia hidrográfica do Rio Piçarras utilizando técnicas de modelagem e geoprocessamento. 2012. 125 p. Dissertação (Mestrado em Ciência e Tecnologia Ambiental) - Universidade do Vale do Itajaí, Itajaí, 2012.

PAIVA, E. M. C. D. Métodos de estimativa da produção de sedimentos em pequenas bacias hidrográficas. In: PAIVA, J. B. D; PAIVA, E. M. C. D. Hidrologia aplicada à gestão de pequenas bacias hidrográficas. Porto Alegre: ABRH, 2003. 628 p.

PARAJULI, P. B., MANKIN, K. R.; BARNES, P. L. Applicability of targeting vegetative filter strips to abate fecal bacteria and sediment yield using SWAT. Agricultural Water Management, v. 95, p. 1189-1200, 2008.

PEREIRA, M. A. F. Processos hidrossedimentológicos em diferentes escalas espaço temporais no Bioma Mata Atlântica. 2010. Dissertação (Mestrado em Engenharia Civil) Universidade Federal de Santa Maria, Santa Maria, 2010. 
PFAFSTETTER, O. Chuvas Intensas no Brasil. $2^{\mathrm{a}}$ ed. Rio de Janeiro: Departamento Nacional de Obras de Saneamento, 1982. 426 p.

POLETTO, K. W. G. Curva chave para o monitoramento automático de sedimentos na Bacia do Rio São Francisco Falso - PR. 2007. Dissertação (Mestrado em Engenharia Agrícola) - Universidade do Oeste do Paraná, Cascavel, 2007.

PRIESTLEY, C. H. B.; TAYLOR, R. J. On the assessment of surface heat flux and evaporation using large-scale parameters. Monthly Weather Review, v. 100, p. 81-92. 1972.

PRUSKI, F., RODRIGUES, L. N.; SILVA, D. D. Modelo hidrológico para estimativa do escoamento superficial em áreas agrícolas. Revista Brasileira de Engenharia Agrícola e Ambiental, Campina Grande, v. 5, n. 2, p. 301-307, 2001.

QUEIROZ, O. T. M. M. Impactos das atividades turísticas em área de reservatório: uma avaliação sócio-ambiental do uso e ocupação na área da represa do Lobo, município de Itirapina, SP. 238p. Tese (Doutorado em Ciências da Engenharia Ambiental) - Escola de Engenharia de São Carlos, Universidade de São Paulo, São Carlos, 2000.

RANA, S. A.; SIMONS, D. B.; MAHMOOD, K. Analysis of sediment sorting in alluvial channels. Journal of the Hydraulics Division, Proceedings of the American Society of Civil Engineers, 1973. 1967-1980.

REGO, J. J. V. Erosão Superficial em taludes de corte em solo residual de gnaisse. 1987. 125 p. Dissertação (Mestrado em Engenharia Civil). Universidade Federal do Rio de Janeiro, Rio de Janeiro, 1987.

REICHARDT, K.; TIMM, L. C. Solo, planta e atmosfera: conceitos, processos e aplicações. Barueri: Manole, 2004. 478 p.

REID, G. K.; WOOD, R. D. Ecology of Island waters and estuaries. New York: D. Van Nostrand, 1976. 485 p. 
REIS, R. S.; CASSIANO, A. M.; ESPINDOLA, E. L. G. Processos sedimentares na represa do Lobo, SP: relação entre o uso do solo e a qualidade da água. In: Programa de Pósgraduação em Ciências da Engenharia Ambiental. (Org.). Recursos hidroenergéticos: usos, impactos e planejamento integrado. $1^{a}$ ed. São Carlos: Rima Editora, 2002, v. 1, p. 117-130.

RENARD, K.G. et al. Revised Universal Soil Loss Equation. Journal of Soil and Water Conservation, v. 46, n. 3, p. 30-33, 1991.

RENNÓ, C. D.; SOARES, J. V. Modelos hidrológicos para gestão Ambiental. São José dos Campos: Instituto Nacional de Pesquisas Espaciais, 2000. Relatório técnico.

RODRIGUES, J. E.; VILLAR, O. M. Estudo da erosão interna em boçorocas através da teoria do carregamento. In: $4^{\circ}$ SIMPÓSIO BRASILEIRO DE GEOLOGIA DE ENGENHARIA, 1984, Belo Horizonte. Anais...São Paulo: ABGE, v. 2, 1984. p. 163- 168.

RIO GRANDE DO SUL; Secretaria da Agricultura. Manual de conservação do solo e água: uso adequado e preservação dos recursos naturais renováveis. $3^{\mathrm{a}}$ ed. Porto Alegre, 1985. 287 p.

RUHOFF, A. L. Gerenciamento de Recursos Hídricos em bacias Hidrográficas: Modelagem ambiental com a simulação de cenários preservacionistas. Santa Maria - RS. 93p. Dissertação (Mestrado em Geomática - Área de Concentração: Sensoriamento Remoto) - Universidade Federal de Santa Maria, 2004.

SALOMÃO, F. X. T.; IWASA, O. Y. Erosão e a ocupação rural e urbana. In: BITAR, O. Y. (Coord.) Curso de geologia aplicada ao meio ambiente. São Paulo: ABGE/IPT, 1995. p. 3157

SÁNCHEZ, L. H. Avaliação de Impacto Ambiental: Conceitos e Métodos. São Paulo: Oficina de Textos, 2006. 496 p.

SANTOS, L. L. Modelos hidráulicos-hidrológicos: Conceitos e aplicações. Revista Brasileira de Geografia Física, v. 2, p. 1-19, 2009. 
SANTOS, R. O. Avaliação da produção de sedimento na bacia hidrográfica do rio Potengi através do modelo SWAT. 2010. 186 p. Dissertação (Mestrado em Engenharia Sanitária) - Universidade Federal do Rio Grande do Norte, Natal, 2010.

SAXTON, K. E.; RAWLS, W. J. Soil water characteristic estimates by texture and organic matter for hydrologic solutions. Soil Science Society of America Journal, Madison, v. 70, p. 1569-1578, 2006.

SCHUBART, H. O. R. O zoneamento ecológico-econômico e a gestão dos recursos hídricos. In: MUNÕZ, H. R. (Org.) Interfaces da gestão dos recursos hídricos: desafios das Leis de Águas de 1997. Brasília: Secretaria de Recursos Hídricos/MMA, 2000.

SHARPLEY, A.N.; WILLIANS, J.R. EPIC - Erosion productivity impact calculator: Model Documentation. Washington: U.S. Department of Agriculture. 1990. 145p.

SILVA, A. M. da; SCHULZ, H. E.; CAMARGO, P. B. de. Erosão e hidrossedimentologia em bacias hidrográficas. São Carlos: Rima, 2003. 320 p.

SILVA, D. A. Levantamento do meio físico das Estações Ecológica e Experimental de Itirapina, São Paulo, Brasil. Revista Instituto Florestal, São Paulo, v. 17, n. 1, p. 113-128, 2005.

SILVA, P. M. O. Modelagem do escoamento superficial e da erosão hídrica na sub-bacia hidrográfica do ribeirão marcela, alto rio grande, MG. 2006. 155 p. Tese (Doutorado em Engenharia Agrícola) - Universidade Federal de Lavras, Lavras, 2006.

SILVA, R. M.; SANTOS, C. A. G. Estimativa da produção de sedimentos mediante uso de um modelo hidrossedimentológico acoplado a um SIG. Revista Brasileira de Engenharia Agrícola e Ambiental, Campina Grande, v.12, n.5, p. 520-526, 2008.

SILVEIRA, A. L. L. Equação para os coeficientes de desagregação de chuva. Revista Brasileira de Recursos Hídricos, Porto Alegre, v. 5, n. 4, p. 143-147, 2000. 
SMITH, R. E.; CORRADINI, C.; MELONE, F. Modeling infiltration for multistorm runoff events. Water Resources Research, v. 29, p. 133-144, 1993.

SOLOMONS, W.; FÖRSTNER, U. Metals in the hydrocycle. Berlin: Springer, 1984. 653 p.

SOUZA, M. L. Proposta de um Sistema de Classificação de Feições Erosivas voltados à Estudos de Procedimentos de Análises de Decisões quanto a Medidas Corretivas, Mitigadoras e Preventivas: Aplicação no Município de Umuarama (PR). 2001. Tese (Doutorado em Geociências e Meio Ambiente) - UNESP, Rio Claro, 2001.

SRINIVASAN, R.; ARNOLD, J. G. Integration of a basin-scale water quality model with GIS. Water Research, v. 30, p. 453-462, 1994.

STEGN, S. G. et al. Sapatial delineation of soil erosion vulnerability in the Lake Taba Basin, Ethiopia. Hydrol. Process., v. 23, 2009.

TIM, U.S. Emerging technologies for hydrologic and water quality modeling research. Transactions of the ASAE,v.39, n. 20, p. 465-476, 1996.

TOLEDO, A. M. A. Evolução espaço-temporal da estrutura da paisagem e sua influência na composição química das águas superficiais dos ribeirões Piracicamirim e Cabras (SP). 2001. 94 p. Dissertação (Mestrado em Ciências) - Escola Superior de Agricultura Luiz de Queiroz, Universidade de São Paulo, Piracicaba, 2001.

TRIPATHI, M. P.; PANDA, R. K.; RAGHUWANSHI, N. S. Identification and prioritization of critical sub-watersheds for soil conservation management using the SWAT model. Biosystems Engineering,London, v. 85, n. 3, p. 365-379, 2003.

TUNDISI, J. G. Impactos ecológicos da construção de represas: aspectos específicos e problemas de manejo. In: TUNDISI, J.G. (Ed.). Limnologia e manejo de represas. São Paulo: ACIESP, 1988. Tomo 1, p.1-75. (Série Monografias em Limnologia). 
TUNDISI, J. G. et al. Gerenciamento e Recuperação das Bacias Hidrográficas dos Rios Itaquerí e do Lobo e da UHE Carlos Botelho (Lobo-Broa). São Carlos, SP. IIE/IIEGA, $72 \mathrm{p}, 2003$.

UZEIKA, T. Aplicabilidade do Modelo SWAT na simulação da produção de sedimentos em pequena bacia hidrográfica rural. 2009. 218 p. Dissertação (Mestrado em Recursos Hídricos e Saneamento Ambiental) - Universidade Federal do Rio Grande do Sul, Porto Alegre, 2009.

VESTENA, L. R. Análise da relação entre a dinâmica de áreas saturadas e o transporte de sedimentos em uma bacia hidrográfica por meio de monitoramento e modelagem. 2008. 268 p. Tese (Doutorado em Engenharia Ambiental) - Universidade Federal de Santa Catarina, Florianópolis, 2008.

WALLING, D. E. Linking the field to the river: sediment delivery from agricultural land. In: BOARDMAN, J.; FOSTER, I. D. L.; DEARING, J .A. Soil Erosion on Agricultural Land. Chichester: Wiley, 1990. p. 129-152.

WALLING, D. E. The sediment delivery problem. Journal of Hydrology, Amsterdam, v. 65, p. 209-237, 1983.

WALLING, D. E.; WEBB, B. W. Material transport by the world's rivers: evolving perspectives. In: RODDA, J. C.; MATALAS, N. C. Water for the Future: Hydrology in Perspective. Proc. Rome Symp, 1987. p. 313-329.

WARD, A. D.; TRIMBLE, S. W. Environmental hydrology. $2^{\text {a }}$ ed. New York: Lewis Publishers, 1995. 475 p.

WILLIAMS, J. R. Flood routing with variable travel time or variable storage coefficients. Transactions of the ASAE, St. Joseph, v. 12, n. 1, p. 100-103, 1969.

WILLIAMS, J. R. The EPIC model. In: SINGH, V.P. Computer models of watershed hydrology. Littleton: Water Resources Publications, 1995. p.909-1000. 
WILLIAMS, J. R. Sediment-yield prediction with Universal Equation using runoff energy factor. In: Present and prospective technology for predicting sediment yield and sources. Oxford: USDA. ARS-S-40, 1975. p.244-252.

WILSON JUNIOR, G. Quando os sedimentos se tornam poluentes. In: II ENCONTRO NACIONAL DE ENGENHARIA DE SEDIMENTOS, 1996, Rio de Janeiro. Anais... Rio de Janeiro, v.1, 1996. P. $199-208$.

WINCHELL, M.; SRINIVASAN, R.; Di LUZIO, M.; ARNOLD, J. ArcSWAT 2.3.4 Interface For SWAT2005: User's Guide. Texas: Blackland Research Center, 2009.

WISCHMEIER, W. H.; SMITH, D. D. Predicting rainfall erosion losses. Guide to Conservation Farming. US Department of Agriculture Handbook, 1978. 58p.

WOOLHISER, D. A.; SMITH, R. E.; GOODRICH, D. C. KINEROS: A kinematic runoff and erosion model: documentation and user manual. USDA - Agricultural Research Service, ARS-77. 1990. 130p.

YOUNG, R. A. et al. AGNPS: a nonpoint-source pollution model for evaluating agricultural watersheds. Journal of Soil and Water Conservation, v. 44, n. 2, p. 168-173, 1989. 